\author{
Universidade de São Paulo \\ Instituto de Física \\ Instituto de Química \\ Instituto de Biociências \\ Faculdade de Educação
}

\title{
A linguagem de vídeos e a natureza da aprendizagem
}

\section{Marcelo de Carvalho Bonetti}

Dissertação de Mestrado apresentada ao Instituto de Física, Instituto de Química, Instituto de Biociências e Faculdade de Educação da Universidade de São Paulo, para a obtenção do título de Mestre em Ensino de Ciências.

Banca examinadora:

Profa. Dra. Yassuko Hosoume (IFUSP)

Prof. Dr. Luís Carlos de Menezes (IFUSP)

Profa. Dra. Adriana Gomes Dickman (PUC-MG) 


\section{FICHA CATALOGRÁFICA}

Preparada pelo Serviço de Biblioteca e Informação do Instituto de Física da Universidade de São Paulo

Bonetti, Marcelo de Carvalho

A linguagem de vídeos e a natureza da aprendizagem São Paulo, 2008.

Dissertação (Mestrado) - Universidade de São Paulo. Instituto de Física - Depto. de Física Experimental

Orientador: Profa. Dra. Yassuko Hosoume

Área de Concentração: Ensino de Ciências

Unitermos: 1. Audiovisual; 2. Material Didático;

3. Ensino; 4. Ciências. 


\section{Resumo:}

Este trabalho pretende identificar elementos presentes em vídeos educativos que contribuem para o aprendizado de conceitos científicos.

Alunos da rede privada e alunos da rede pública de ensino no $1^{\circ}$ ano do Ensino Médio de São Paulo assistiram aos episódios de dois seriados veiculados em TV aberta, um com formato televisivo e o outro mais parecido com a aula tradicional. Para cada um dos seriados foram selecionados dois episódios, um sobre as alavancas e outro sobre o princípio de vôo do avião.

Os resultados indicam que, individualmente, os episódios contribuem para o aprendizado de conteúdos científicos, e com desempenho bastante semelhante. Há pequenas diferenças ligadas ao fato de os alunos responderem com melhor desempenho a perguntas que tenham a mesma forma com que o tema foi desenvolvido no vídeo. Já os mesmos episódios contribuem de forma cooperativa, quando são exibidos para um mesmo grupo de alunos, obtendo-se, assim, melhoras significativas no aprendizado dos conceitos científicos em grupos. A linguagem dos vídeos promove forma de aprendizagem de natureza distinta e complementar.

Dessa forma, encontramos indícios de que os vídeos prazerosos devem ser mais valorizados no ensino, pois são tão educativos quanto vídeos monótonos. Também identificamos que realizadores de audiovisuais educativos devem ter consciência da cooperação que ocorre quando se mesclam momentos de sistematização e momentos de prazer num audiovisual, o que pode ser contemplado por professores que utilizem vídeos de naturezas distintas. 


\begin{abstract}
:
In this work we identify the aspects of educational videos that contribute to students' learning of scientific concepts.

Students in the first year of high school, from both public and private schools, watched two episodes about levers and two about the principle of airplane flight from two different TV series. While one episode explores the subjects in a contextualized way, the other is similar to a traditional class.

Our results indicate that each episode contributes to the learning of scientific concepts in a very similar way. However, there are small differences in performance, due to the fact that students show better learning when the questions have the same format as developed in the video. We find that two episodes, about the same subject, work in a cooperative way when shown to the same group of students. The results show significant improvement in the students' learning. The approaches of the two videos promote learning in distinct and complementary ways. Thus, we find that contextualized videos should be preferred in teaching, since they teach as much as unengaging videos.
\end{abstract}

We also point out that educational video makers should be aware of the cooperative advantages of alternating moments of pleasure and of systematization. In fact, this can also be attempted by teachers using videos of distinct nature. 
- Para men Sho

Oinarle Bonelli 


\section{Agradecimentos}

A todos aqueles que contribuíram para que eu chegasse aqui e que não foram poucos nesses anos.

Ao Hélio e ao Maurício, amigos que nunca me faltaram.

Aos amigos do IFUSP, parceiros fiéis a mais de 20 anos, principalmente à Rebeca, amiga e educadora que admiro.

À Sônia Marmelsztejn por me ajudar em tempos difíceis.

À família Gruenwald e Jacques Lépine que ensinaram-me a virtude da humildade.

À Yassuko pelo profissionalismo, pela orientação, pelo carinho, pelo apoio e pela amizade.

Ao Menezes e ao Robilotta, por iluminarem minhas reflexões sobre a realidade e porque inspiram-me a ser uma pessoa melhor.

À Soninha pela amizade e por desfrutarmos de trabalhos gratificantes.

À Cristina, Patrícia e Sandra por compartilharem de meus sonhos.

Ao meu pai, por estar sempre por perto, por realçar o valor do conhecimento, por me ensinar a voar e trazer mais adrenalina à minha vida.

Aos irmãos de sangue ou não, pelo apoio.

À Dilcéia por acreditar em mim mais do que eu mesmo.

Aos meus filhos Luan e Romualdo, pela felicidade que me proporcionaram durante a realização desse trabalho . 


\section{Sumário:}

A IMPORTÂNCIA DO AUDIOVISUAL EM NOSSA SOCIEDADE ................................................9

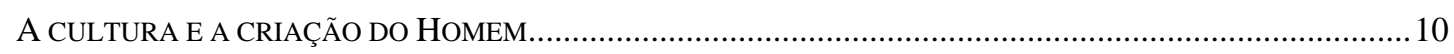

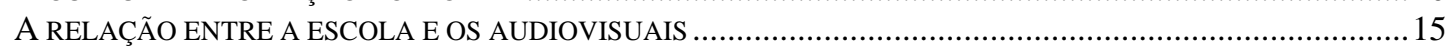

OS AUDIOVISUAIS NA EDUCAÇÃO A DISTÂNCIA (EAD) ..........................................................25

3. OS AUDIOVISUAIS NO ENSINO DE FÍSICA .........................................................................36

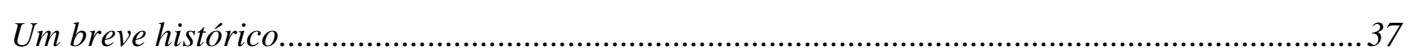

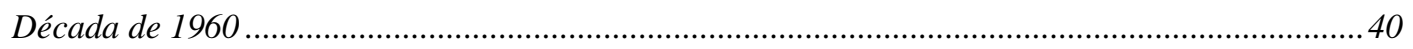

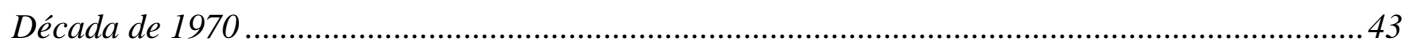

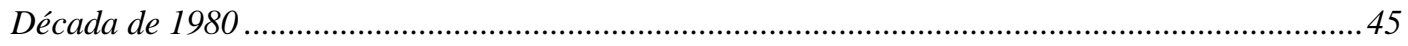

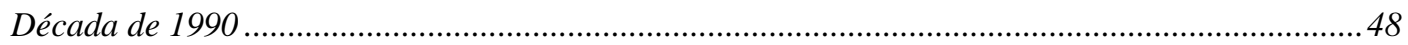

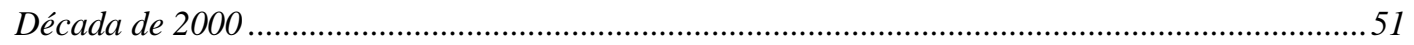

4. OS AUDIOVISUAIS NA PESQUISA EM ENSINO DE FÍSICA......................................................57

A CONSTRUÇÃO DE SIGNIFICADO: UM PROCESSO DINÂMICO …………………………………….......57

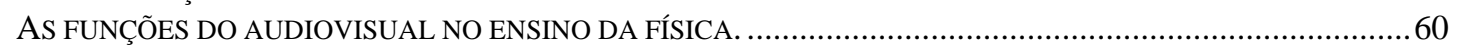

5. A PESQUISA REALIZADA ................................................................................................................. 70

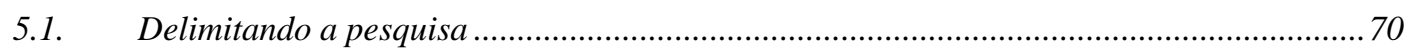

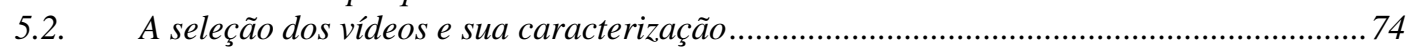

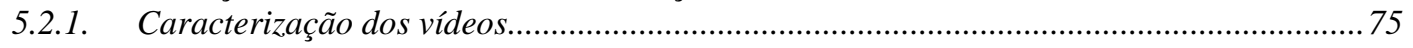

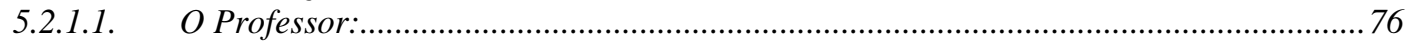

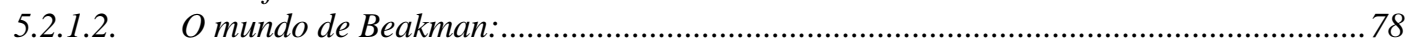

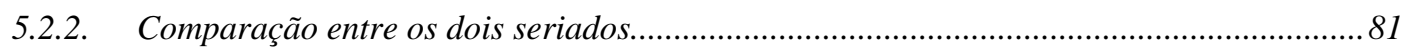

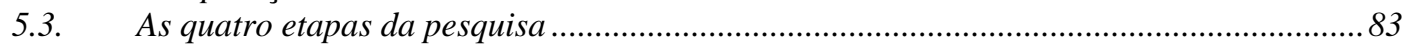

5.4. A primeira etapa: procurando os primeiros indícios ...........................................................8

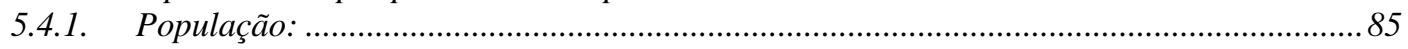

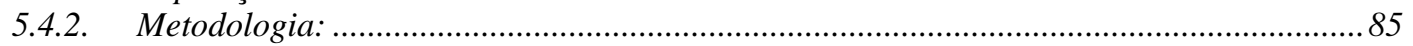

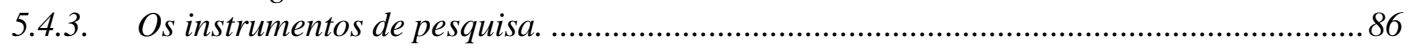

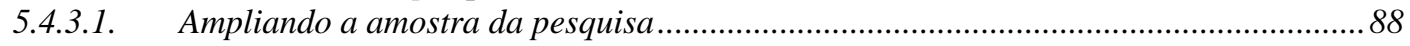

5.4.4. Resultados: análise das respostas dos Grupos I, II e III ................................................... 90

5.5. A segunda etapa: analisando a ordem das projeções dos vídeos.......................................101

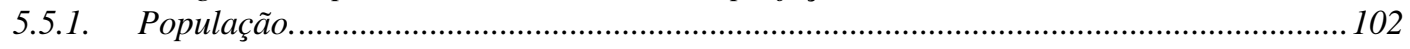

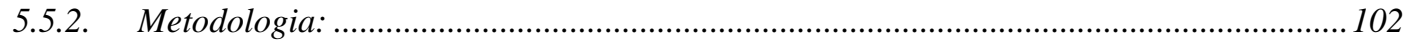

5.5.3. Os instrumentos de pesquisa. ....................................................................................103

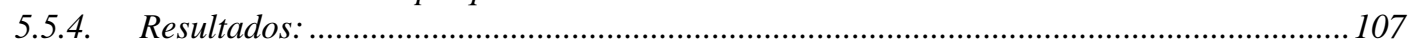

5.6. A terceira etapa: mudando a natureza dos vídeos e variando as amostras ......................116

5.6.1. População...............................................................................................................117

5.6.2. Metodologia: .....................................................................................................117

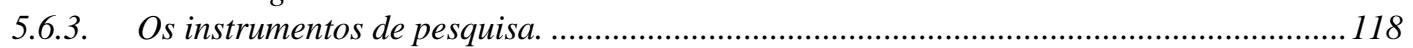

5.7. A quarta etapa: invertendo a aplicação dos pós-testes .......................................................121

5.7.1. População................................................................................................................121

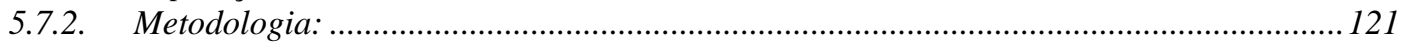

5.7.3. Os instrumentos de pesquisa. .......................................................................................122

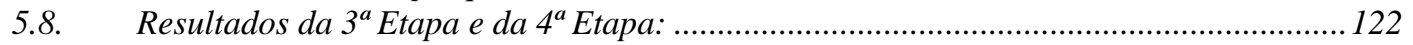

5.9. Considerações finais sobre a pesquisa realizada ..............................................................157

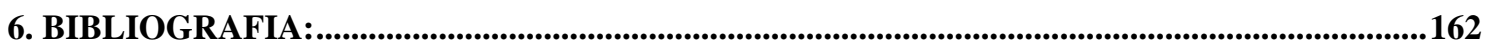

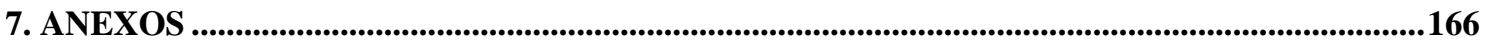

Anexo 1: Elementos da linguagem audiovisual.........................................................................167 


\section{Índice de tabelas:}

Tabela 1: Alavanca em que se aplica a menor força. ................................................... 90

Tabela 2: Exemplos de alavanca que os alunos reconhecem em seu cotidiano............. 91

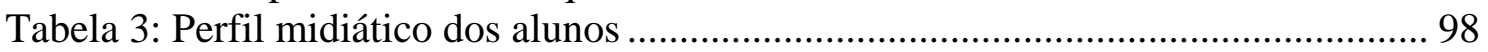

\section{Índice de gráficos:}

Gráfico 1: Avanços identificados no pós-teste e alterações das respostas do pré-teste. 93

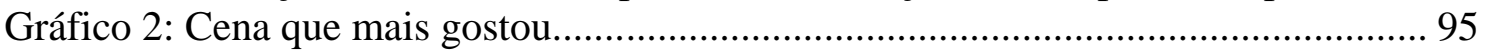

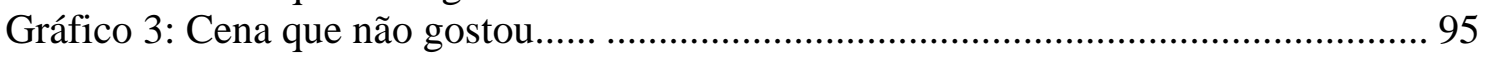

Gráfico 4: Vídeo que na opnião dos alunos ensina mais física. ................................. 97

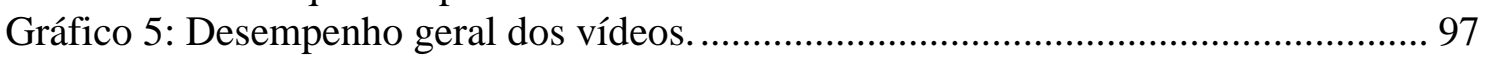

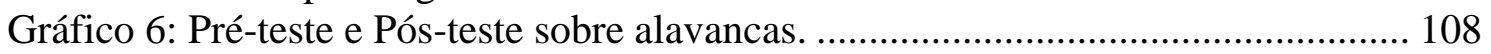

Gráfico 7: Identificar numa gangorra elementos de uma alavanca ............................. 109

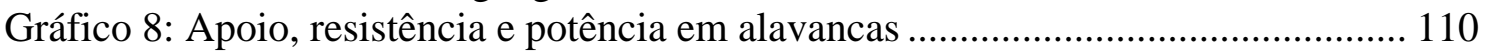

Gráfico 9: Como cortar um papelão com mais facilidade usando uma tesoura. ........... 112

Gráfico 10: As alavancas no cotidiano - portas e bandeiras......................................... 113

Gráfico 11: As alavancas no corpo humano - o braço .................................................... 114

Gráfico 12: O avião e o mundo vivencial do aluno - distribuição por categoria......... 125

Gráfico 13: O avião e o mundo vivencial do aluno - distribuição por grupo .............. 126

Gráfico 14: Coisas que voam, além do avião - distribuição por categoria. .................. 128

Gráfico 15: Coisas que voam, além do avião - distribuição por grupo......................... 129

Gráfico 16: Quais partes do avião permitem que ele fique no ar - distribuição por

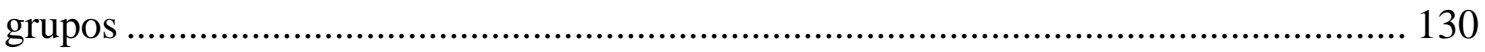

Gráfico 17: Quais partes do avião permitem que ele fique no ar - distribuição por

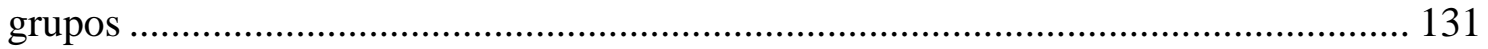

Gráfico 18: Quais partes do avião permitem que ele fique no ar - distribuição por

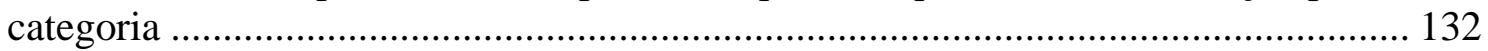

Gráfico 19: Voa sem ter motor - distribuição por categoria........................................ 133

Gráfico 20: Voa sem ter asas - distribuição por categoria .......................................... 134

Gráfico 21: Balões e dirigíveis voam sem ter asas..................................................... 135

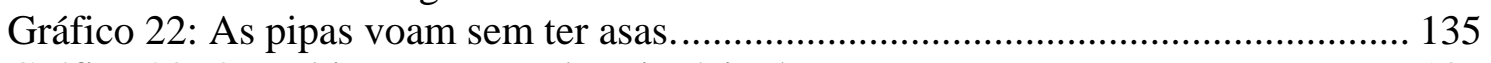

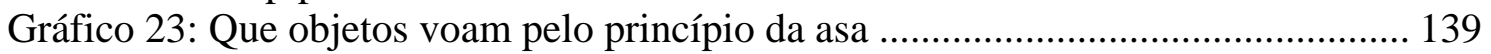

Gráfico 24: Identificar a semelhança entre o perfil da asa e de um carro ...................... 141

Gráfico 25: Como se pode melhorar o vôo de um avião de papel................................ 143

Gráfico 26: Principais componentes de um avião e suas funções no vôo ...................... 148

Gráfico 27: Principais componentes de um helicóptero e suas funções no vôo............ 150

Gráfico 28: Identificar a semelhança entre o perfil da asa e de um carro .................... 152

Gráfico 29: Comparar as trajetórias de um dirigível, um helicóptero e um avião após

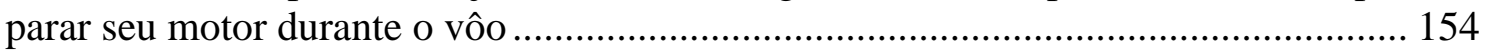




\section{A importância do audiovisual em nossa sociedade}

"Observar o comportamento dos jovens em idade escolar, já criados numa convivência íntima com os videogames, televisões e computadores, pode ser significativo para entender, por um lado, algumas das razões do fracasso da escola atual e, por outro, alguns elementos para uma possível superação desses fracassos." (Pretto, 1994, p. 92)

O mundo em que vivemos está repleto de imagens e sons, entre outros estímulos; é um mundo de comunicação, em que os sentidos, as emoções e a razão são estimulados e interagem criando a nossa cultura e humanidade.

As imagens e sons que guardamos dos acontecimentos são alguns exemplos que ilustram a força e a presença dos audiovisuais em nossa sociedade. Põem-se diante do mundo o assassinato de J. F. Kennedy, a chegada do Homem à Lua, as "Diretas Já!", o enterro de Tancredo Neves, as vitórias de Ayrton Senna e a comoção de sua morte, os "caras-pintadas" agitando o Brasil, o impeachment do presidente Fernando Collor de Mello, as torres do World Trade Center desabando, a conquista do pentacampeonato mundial de futebol pelo Brasil, o astronauta brasileiro na Estação Orbital Internacional. Hoje, essa avalanche de imagens e sons se amplia e se agiliza numa pista de mão dupla, na interatividade on line da Internet, criando uma nova perspectiva de "ação humana", num mundo em que realidade e ficção se confundem, o chamado mundo virtual, que já apresenta reflexos e interconexões com o mundo real.

O conhecimento da história dessa vertiginosa escalada, que levou à imersão do Homem num mundo virtual, está fortemente ligado ao 
desenvolvimento da linguagem audiovisual, e foi isso que nos incentivou a procurar entender como esse desenvolvimento se deu, especificamente no que se refere aos audiovisuais realizados para o ensino da Física, e quais as características dessa linguagem que podem favorecer o ensino da Física.

\section{A cultura e a criação do Homem}

O ser humano é singular entre os animais por ser capaz de criar a sua própria existência. O homem surge ao mesmo tempo em que surge a cultura humana. Sendo ambos indissociáveis, compõem um único processo: o de hominização ${ }^{1}$. A transformação do animal em ser humano baseia-se na cultura e no convívio social regido por leis socioeconômicas e não por leis biológicas.

O acúmulo da experiência na cultura, resultante da transmissão dos conhecimentos de uma geração para outra, distingue-nos dos animais. Criamos novas formas de comunicação, novas linguagens, instrumentos e equipamentos que são extensões de nossos sentidos e de nosso corpo, e até da realidade, os quais nos permitem transformar o meio que vivemos, como o homem no passado jamais poderia fazer ou mesmo sonhar.

“...inovar as operações que exerce sobre a natureza, e com isso praticar atos inéditos, desconhecidos no passado da espécie. Tais atos vão-se acumulando na consciência comunitária, graças à hereditariedade social dos conhecimentos adquiridos, porque em virtude de favoráveis resultados que propiciam, são recolhidos, conservados e transmitidos de uma geração a outra." (Pinto, 1985, p. 122)

\footnotetext{
${ }^{1}$ Pinto, 1985, p. 122.
} 
A capacidade de intervir no mundo manifesta-se na produção intencional de instrumentos, desde a pedra lascada até a construção de um mundo virtual paralelo ao real, na rede mundial de computadores.

"O homem, por definição, é o ser que se propõe por finalidade a criação da realidade em que deseja existir. ... O homem se define como o ser capaz de projetar o seu ser, de conceber por finalidade o que quer ser." (Pinto, 1985, p. 281)

A edificação do conhecimento é um processo histórico e progressivo, por um lado é construído na ação humana e por outro também a organiza. O conhecimento adquirido é premissa para os novos conhecimentos, seja para sua ampliação, seja para sua superação.

A realidade apreendida pelo homem também é transformada pelo conhecimento humano, de forma que novos fins podem ser propostos pela consciência humana, num processo histórico de evolução do que entendemos por real e que transmitimos às novas gerações.

Assim, o conhecimento apresenta-se como produto, sendo ele próprio "consumido" pelo homem na apropriação da cultura, o que ocorre, na sociedade escolarizada, principalmente por meio da educação.

Vemos, dessa forma, que o conhecimento apresenta uma característica importante ao se estabelecer como processo e produto, numa relação dialética. A cultura, interpretada como produto do processo produtivo, é um bem de consumo, e, ao mesmo tempo, interpretada como acervo de conhecimento e de instrumentos que permitem a exploração do mundo e sua transformação, caracteriza-se como bem de produção, expressando-se assim sua dupla natureza. 
O entendimento dessas duas facetas mostra-se especialmente importante porque, em sociedades que impõem uma desigualdade social discrepante, ocorre a cisão entre aqueles que têm acesso à cultura como processo de produção, e aqueles que têm acesso à cultura como bem de consumo. Os primeiros, denominados "cultos", são reconhecidos socialmente como os "produtores da cultura", enquanto os denominados "incultos" são reconhecidos apenas como meros consumidores da cultura.

Esse é um processo alienante, já que, nessa estrutura social, o homem, em vez de apropriar-se da cultura, de dominá-la, faz o inverso, aliena-se a ela, transformando-a numa entidade superior a ele, na contramão da hominização.

A diferenciação do papel existencial desempenhado pelos homens no processo produtivo de si mesmos e dos bens de que precisam para subsistir estabelece as classes sociais. Chega-se ao extremo de o próprio homem transformar-se em bem de consumo, no ápice da alienação cultural, num processo injusto e desumano que reifica o ser.

"A cultura é uma realização do homem coetânea à realização de si mesmo pela ação produtiva. Deveria ser apanágio da espécie, como tal, ou seja, não existir diferenciada entre classes de indivíduos." (Pinto, 1985, p. 127)

O homem pode utilizar os audiovisuais tanto para coibir a alienação cultural, quanto para produzi-la, e por isso entendemos que a educação escolar deva incorporar o estudo da linguagem audiovisual entre seus objetos de conhecimento, para que seu entendimento seja utilizado na apropriação da cultura, não permitindo a alienação cultural. 
O primeiro elemento que vamos analisar na linguagem audiovisual é seu caráter pré-lógico, porquanto ela mexe com os sentimentos antes de interagir com a razão, sendo isso fundamental para se entender a relação que pode ser estabelecida entre a comunicação com a linguagem audiovisual e a educação.

Os audiovisuais, no caso dos filmes, sejam eles dramas, suspenses ou de terror, explicitam como a emoção e a razão emergem e interagem nas situações em que a sensibilidade ou a emoção nos fazem chorar, a simpatia ou a injustiça imposta a um personagem alteram os valores pelos quais julgamos suas ações, o conhecimento da potencial ação do vilão promove palpitação no coração e nos impele a avisar alguém que se encontra em perigo, ainda que se tenha total consciência de se tratar da trama de um filme.

Sentir apreço e carinho por um personagem, admirar algumas de suas características, identificar-se com a trama, podem fazer muita diferença na relação que se estabelece com o conteúdo educacional ou com a trama apresentada num audiovisual.

É bom lembrar que o mesmo acontece na relação estabelecida entre alunos e professor na sala de aula: os sentimentos acompanham-nos em todas as situações, mesmo quando já não nos damos conta deles em nome de uma impessoalidade profissional.

Filmes, desenhos animados, propagandas, seriados, telejornais... As imagens e sons divulgam visões de ética, conceitos de moral, estilos de vida etc., ideologias que estão sempre presentes nas ações e situações enfrentadas pelos personagens da ficção ou pelos da vida real.

Nesse sentido, há muito tempo os governos têm-se valido da produção de filmes educativos ou promocionais para orientar os cidadãos, tanto em 
situações em que a coletividade deve proceder de forma homogênea, em caso de furacões e outras catástrofes naturais, guerras, pestes, como para manipular os cidadãos, de formas mais, ou menos, explicitamente ideológicas, nos regimes de exceção e nos impérios culturais.

As grandes potências culturais exportam seus produtos audiovisuais para promover uma colonização cultural, como se viu na Guerra Fria e como ocorre ainda hoje em filmes e seriados que discutem o terrorismo, o perigo da guerra nuclear, a produção e o tráfico de drogas, entre outros problemas enfrentados na modernidade. Esses seriados, filmes comerciais e programas de auditório disseminam valores, preceitos culturais, morais e ideológicos, promovendo a educação de suas colônias culturais.

É importante entender como a importação de audiovisuais contribui para promover mudanças em nossa cultura. Modificam-se os costumes, ditam-se as modas, insufla-se o consumo, inventam-se necessidades, modificam-se os padrões estéticos, sociais, culturais, através da exposição incessante à cultura dominadora. É bom nos perguntarmos de onde vieram hábitos como comer lanches com picles, usar calças jeans, tomar Coca-Cola, o que fazemos de forma tão natural, até mesmo podemos aprender a sentir falta das Torres Gêmeas em Nova lorque, sem nunca termos estado lá.

É relevante nesse momento relembrar que, ao consumirmos o cinema estrangeiro, principalmente quando se trata do audiovisual educativo, podemos correr o risco de promover a alienação cultural, aceitando um modelo de colonização cultural utilizado pelas metrópoles.

De maneira análoga, no Brasil, grandes centros urbanos que são pólos de produção cultural também exercem influência no restante do país. Redes 
nacionais de televisão como a Globo, a Record, a Bandeirantes, o Sistema Brasileiro de Televisão, com sede na região sudeste ditam padrões de comportamentos típicos do eixo Rio-São Paulo e também promovem uma forma de colonização cultural.

Os audiovisuais são expressões de modelos e formas culturais que podem ser considerados educativos em determinado contexto, porém em outra circunstância e cultura podem ser tidos como inaceitáveis.

Durante a Guerra Fria, foram inúmeros os filmes que no Ocidente enalteciam os assassinos mercenários, ou assassinos sob a égide militar, que defendiam a "democracia" americana, trazendo uma imagem negativa do "comunismo", veiculando determinados valores sociais. De forma similar, no Leste Europeu e na URSS, filmes enalteciam o regime comunista e traziam uma imagem negativa do Ocidente, veiculando outros valores sociais. Ambos são educativos, cada um a serviço de um modelo de sociedade.

\section{A relação entre a escola e os audiovisuais}

Tomemos esses aspectos da cultura para entender a inserção dos audiovisuais na educação. Na maioria das escolas, os audiovisuais ainda são tomados como bem de consumo, como material de ilustração para os conhecimentos discutidos em sala de aula. Nesse sentido, os audiovisuais estão sendo utilizados para a alienação cultural. $\mathrm{Na}$ interação com $\mathrm{o}$ espectador, o audiovisual está destituído de seu papel formativo, que pode ser alcançado com a utilização de metodologia adequada que promove seu potencial transformador, propiciando ao espectador a construção de si mesmo.

"(em pesquisa com professores) ...os momentos, objetivos principais e metodologias com que utilizam os audiovisuais (o 
videocassete principalmente) na sala de aula, podem ser resumidos assim: "para introduzir um assunto novo", "para ilustrar a aula", "para reforçar uma aula dada", ou mesmo "para relaxar", fazer a aula ficar mais leve." (Miléo, 1994, p. 109)

Esse emprego do audiovisual, baseado em seu conteúdo disciplinar, fragmentado e excessivamente racional, que na maioria dos casos busca apenas o reforço à aula expositiva ou experimental, acaba por tratar o aprendizado como um processo de persistência, baseado na "retenção" da informação por meio da repetição. Sem que o conhecimento seja elaborado pelo aluno, o processo de ensino-aprendizado não se traduz em transformação, o que leva à alienação cultural.

O aluno que não entende algo, não se apropria do conhecimento por simples repetição do mesmo procedimento; se o audiovisual reproduz da mesma forma aquilo que o aluno não entende na aula expositiva, o aluno continuará não entendendo, pois não é a repetição, muitas vezes de uma mesma forma, que dará condições de ele apreender esse conteúdo. É necessário que ele investigue o objeto de conhecimento de muitas formas, interagindo de maneiras distintas, sendo protagonista de seu conhecimento.

É justamente por isso que é importante explorar os elementos da linguagem audiovisual e o potencial que desempenham no aprendizado do aluno, já que Ihe propiciam novas formas de interação com o conhecimento, as quais estão fora do alcance do professor numa sala de aula.

Além de poder apresentar de formas diferentes um mesmo objeto, em seu papel formativo, explorando a linguagem audiovisual em todo o seu potencial, os audiovisuais trabalham ora com enfoques mais emotivos, ora 
mais racionais, ora apresentando o conhecimento, ora explorando as sensações e emoções trazidas ao espectador.

Assim, os audiovisuais podem auxiliar o professor, que mantém seu papel fundamental no ensino escolar, já que o professor é quem pode identificar as dificuldades dos alunos e propor estratégias distintas a fim de propiciar o aprendizado deles, inclusive ao utilizar adequadamente os audiovisuais, dando a oportunidade de os alunos comporem uma visão com muitas facetas do mesmo objeto, e assim poderem compreendê-lo.

As crianças, jovens e adolescentes, em idade escolar, e também os adultos, a todo tempo estão submetidos aos mais variados recursos audiovisuais, que de alguma forma estão educando-os, seja em casa, no cinema, nos meios de divulgação eletrônicos, na Internet etc.

É nesse sentido que as escolas precisam incorporar às suas estratégias de ensino essa linguagem amplamente difundida em nosso cotidiano, a qual tem colaborado para a formação dos indivíduos e da cultura no mundo contemporâneo. No entanto, as instituições de ensino ainda estão muito distantes dos ambientes audiovisuais que permeiam nossa vida.

"A modernidade é audiovisual. Essa é a premissa de que deve partir a educação hoje. Essa modernidade, no entanto, impregna a realidade social e psicológica dos indivíduos. A escola não precisa criá-la artificialmente no estrito contexto dos mecanismos formais de ensino/aprendizagem. O educador deve buscar a compreensão da natureza dos processos de realização e fruição da linguagem audiovisual." (Franco, 1987, p. 41) 
Para compreender mais completamente essa modernidade audiovisual, é necessário incorporar, além das tecnologias, os fazeres associados a elas, como realização, produção, roteirização, iluminação, dramaturgia, cenografia, figurino, e também promover a análise crítica e técnica das produções comerciais e da televisão a partir do conhecimento da linguagem audiovisual.

A história mostra que, apesar dos muitos percalços e do distanciamento que ainda estão presentes nas escolas, temos conseguido avançar e amadurecer nas relações que estabelecemos entre a educação e os ambientes e produtos audiovisuais.

Baseando-nos em valores morais, consideramos as ações certas ou erradas, e tendemos a afirmar que os comportamentos, palavras, histórias que julgamos imorais deseducam e não devem ser estimulados nem veiculados. Nessa concepção, os vídeos educativos são aqueles voltados ao ensino de conhecimentos escolares e aqueles voltados à ética, moral e bons costumes. Em 1910, quando o cinema se delineava como meio de comunicação de massa, nos grandes centros produtores, pensava-se no cinema escolar dessa forma, um cinema escolar moral que se mostrava como oposição ao cinema de entretenimento. Também foi constituída a censura, como uma possibilidade de evitar a exibição de filmes julgados inconvenientes, pois afinal já era conhecido o poder sugestivo da tela.

A oposição que se faz, ainda hoje, entre o cinema educativo e o cinema de entretenimento, a qual tem razões históricas, é um grande equívoco, pois a fruição - ato de aproveitar satisfatoriamente e prazerosamente - é uma característica da linguagem audiovisual. 
“... não se pode ter a ingenuidade, ou a pretensão, de querer 'enxugar' da linguagem audiovisual a sua essência emocional para que venha a servir à ação racional de instrução." (Franco, 1987, p. 166)

Muitos filmes do gênero educativo apresentam seqüências de imagens que ilustram uma narração verbal. Estas produções, além de apresentarem a característica "bancária" (Freire, 1974) indesejável à autonomia e criticidade do educando, também são monótonas e tediosas.

No Brasil, também se encontra em documentos oficiais, relatórios de diretorias de ensino e livros, o registro dessa oposição entre o que se chamou cinema recreativo e o cinema educativo ${ }^{2}$; porém, na produção nacional não houve esse conflito entre o cinema de entretenimento e o cinema educativo.

A criação do INCE - Instituto Nacional de Cinema Educativo, implantado por Roquette-Pinto, respaldado por Fernando de Azevedo, Anísio Teixeira, Gustavo Capanema, e contando com o diretor-técnico Humberto Mauro, traz ao cinema educativo uma proposta de produção pautada na linguagem cinematográfica, não como oposição ao cinema de entretenimento. É um cinema que se propôs a uma educação mais ampla e cultural, não à educação meramente escolar ${ }^{3}$.

Buscando evitar a sobreposição de significados ao cinema educativo, e realçando a natureza educativa dos audiovisuais, Roquette-Pinto fazia uma diferenciação entre o cinema educativo e o cinema instrutivo, e alertava que mesmo entre os mais esclarecidos muitas vezes se faz confusão entre eles, como podemos ver em suas palavras:

\footnotetext{
${ }^{2}$ Ver Saliba, Maria Eneida Fachini . Cinema contra cinema : o cinema educativo de Canuto Mendes", 2003.

${ }^{3}$ Ver Franco, Marília da Silva, 1987, p. 38.
} 
“...não é raro encontrar, mesmo no conceito de pessoas esclarecidas, certa confusão entre o cinema educativo e o cinema instrutivo. É certo que os dois andam sempre juntos e muitas vezes é difícil ou impossível dizer onde acaba um e começa o outro, distinção aliás que não tem de fato grande importância na maioria das vezes. No entanto é curioso notar que o chamado cinema educativo, em geral não passa de simples cinema de instrução. Porque o verdadeiro cinema educativo é outro, o grande cinema de espetáculo, o cinema da vida integral. Educação é principalmente ginástica do sentimento, aquisição de hábitos e costumes de moralidade, de higiene, de sociabilidade, de trabalho e até mesmo de validação... A instrução dirige-se principalmente à inteligência. O indivíduo pode instruir-se sozinho; mas não pode se educar senão em sociedade." (Roquette-Pinto, apud Franco, 1987, p. 27)

A produção do INCE (1936-1966) foi vasta e não apresentou uma linha pedagógica ou uma clara articulação entre a produção de filmes e os programas de ensino; foram produzidos filmes de Geografia, Música, Medicina, Educação Rural, Ciências, Indústria, História, embora não se identifique uniformidade nem quanto à proposta didática, nem quanto ao nível de ensino ${ }^{4}$.

Essa produção, que era realizada principalmente em películas de $16 \mathrm{~mm}$, necessitava, para seu uso, da exposição em uma sala de projeção com um aparelho projetor que era um equipamento complexo e de difícil operação. Para tanto, era necessário um técnico, e esse foi um dos motivos que dificultou

\footnotetext{
${ }^{4}$ Franco, 1987, p.36-37.
} 
o uso escolar da produção do INCE, bem como o uso de muitos outros audiovisuais também em películas realizados para o ensino nessa mesma época.

As escolas públicas não tinham técnicos com conhecimentos para operar os projetores, e por isso apenas mantiveram em seu patrimônio os projetores $16 \mathrm{~mm}$, os quais, sem uso algum, deterioraram-se ao longo dos $\operatorname{anos}^{5}$.

$\mathrm{Na}$ história recente também podemos identificar tentativas de inserção do audiovisual nas escolas, as quais freqüentemente ocorreram sem o investimento adequado no principal agente dessa transformação, que é o professor. O que se observa é o investimento tecnológico, com a compra de equipamentos e com a produção de filmes educativos, juntamente com o investimento nas formas de distribuição, sem a contrapartida de investimento na ação docente.

Mesmo em relação a outras tecnologias como o computador, ou Internet, esse padrão se repete, sendo possível, também, identificar investimentos em tecnologia, compra de equipamentos, estruturação de salas de informática, aquisição de softwares, programas educativos e multimídias em CD e DVD, mostrando-se uma forma recorrente de promover uma relação entre a educação e a tecnologia a qual busca transcender aqueles que efetivamente implementam os projetos: os professores. É dessa forma que a implementação das novas tecnologias acaba muitas vezes fadada ao insucesso, como também veio a ocorrer com a "primeira onda" de informatização das escolas.

\footnotetext{
${ }^{5}$ Franco, 1987, p. 24.
} 
Mesmo a TV Escola acaba exemplificando essa forma de atuação do governo na educação. Criada em 1995, iniciou-se com investimentos em equipamentos: foram compradas as antenas parabólicas, aparelhos de televisão e os videocassetes para cada escola. Investiu-se em direitos de transmissão para programas, seriados, filmes educativos, liberando-se também verbas para a realização de programas e de animações especificamente elaborados para a TV Escola, e já em 1996 iniciou-se sua transmissão aberta. A estrutura física e os recursos humanos para sua implementação ficavam a cargo dos estados e dos municípios.

Só em 2000 o Ministério da Educação ofereceu em âmbito nacional o curso de extensão "TV na Escola e os Desafios de Hoje". Novamente vemos que não houve um investimento sistemático na ação docente, o que pode ser constatado pela enorme demanda de professores da rede pública que se inscreveram para o curso.

"(o curso de extensão) tinha como meta inicial alcançar 30.000 educadores de todo o território brasileiro, porém o número de inscritos superou a expectativa da Secretaria de Educação a Distância, totalizando 254.318 inscrições enviadas. Deste total foram matriculados 34.740 educadores, o que nos permite analisar que a demanda por capacitação é algo urgente." (Berger e Nunes, 2004, p. 27)

Qualquer projeto de ensino que incorpore os audiovisuais torna-se inviável ao se deparar com um professor avesso ou acuado frente a essa tecnologia. Sem incentivo e subsídios técnicos, ele jamais utilizará esses equipamentos tecnológicos; é preciso encorajá-lo e estimulá-lo à aproximação 
com esses recursos. Ainda está por fazer um trabalho em dimensão nacional com o intuito de favorecer uma relação amigável entre os professores e as novas tecnologias.

$\mathrm{Na}$ formação inicial de nossos educadores, raramente vemos um trabalho sistemático que leve em consideração o uso pedagógico dos audiovisuais, das redes como a Internet, etc. Essa lacuna pode contribuir para um uso inadequado e até mesmo preconceituoso desses meios em sala de aula, como aqueles apresentados no início desta reflexão.

O uso do audiovisual é uma estratégia de ensino e tanto pode romper com o ensino tradicional, como pode também reforçá-lo, pois não é o audiovisual que irá mudar a postura do professor.

Um uso adequado dos audiovisuais e também das novas tecnologias, retira o professor do pedestal e o recoloca como espectador especializado; retirado da condição de "quem sabe", deixa de exercer o controle sobre o que será apresentado, passando a haver um novo eixo de aprendizado no qual ele não pode interferir, mas no qual sua contribuição é crucial para trazer ao diálogo elementos de aprofundamento, agindo como espectador especializado, trazendo novos conhecimentos que não foram abordados no audiovisual ou ainda traçando paralelos com outros conhecimentos escolares ou nãoescolares, presentes no debate em sala de aula.

Para um educador, o audiovisual é um forte aliado, pois além de ser estimulante para os alunos, ele pluraliza o processo educacional, apresentando-se como outra possibilidade de diálogo, trazendo diferentes olhares, com uma dinâmica e um tempo próprios do mundo moderno e da juventude, servindo também de estímulo ao professor. 
A fruição é um objetivo planejado num audiovisual e torna o aprendizado mais alegre e saboroso, não sendo preciso ver filmes monótonos e informativos para aprender; pelo contrário, é com prazer e com os sentimentos despertados pelos audiovisuais que se estimula o processo de aprendizado.

Em geral não nos damos conta da importância das emoções e dos sentimentos no processo de aprendizagem; tratamos o aprendizado como algo puramente cognitivo, racional e lógico. As salas de aula tradicionais normalmente são a mais completa tradução disso: silêncio é sinônimo de seriedade; criatividade e expressão durante a aula devem restringir-se às perguntas ao professor; os conhecimentos propedêuticos devem ser estudados e reproduzidos. Os audiovisuais podem trazer nossos medos, raivas, alegrias, prazeres, ansiedades, desejos, emoções e toda a vida à sala de aula.

Para entrar em consonância com um novo paradigma audiovisual, não basta apresentar um vídeo ou discutir um filme em sala de aula, muito menos apenas responder a algumas questões sobre os conteúdos específicos do audiovisual. As emoções, os sentimentos devem estar presentes em seu trabalho, são parte do novo paradigma, e é dessa forma que nos apropriarmos de todo potencial que a linguagem audiovisual nos traz.

É certo que há uma parcela significativa do aprendizado dos educandos associada à razão e que deve ser valorizada, mas não demasiadamente como na educação tradicional. A linguagem audiovisual nos ajuda a contemplar e ampliar essa fronteira, trazendo vida ao conhecimento, e nós, educadores, precisamos estar abertos a novas formas de avaliar e de interpretar esse processo educativo, que deve ser mensurado a partir da produção dos alunos: ele não pode ser mensurado com uma prova. 


\section{Os audiovisuais na Educação a Distância (EAD)}

A educação a distância (EAD) desempenhou um papel importante na produção de audiovisuais educativos; nela os audiovisuais sempre tiveram e ainda têm um papel de destaque, ao lado dos textos escritos e das mídias digitais atuais.

Conhecer a trajetória e a relação entre os audiovisuais e a EAD pode ajudar-nos a entender algumas causas da ausência dos audiovisuais nas salas de aula, principalmente os audiovisuais de entretenimento, em que a fruição fica evidenciada como objetivo almejado.

No Brasil, os audiovisuais estão presentes nessa modalidade de ensino desde 1960, e foram pensados e incorporados de muitas formas ${ }^{6}$ : em projetos de Alfabetização de Adultos, Educação Infantil, ensino de $5^{\mathrm{a}}$ a $8^{\mathrm{a}}$ séries do $1^{\circ}$ Grau, ensino de 2. ${ }^{\circ}$ Grau, Ensino Profissionalizante e também no Ensino Superior, inclusive na formação continuada. Além disso, foram utilizados na preparação de exames de certificação $^{7}$ e na preparação para processos seletivos, como os vestibulares.

Hoje o emprego de audiovisuais para capacitação docente é uma política pública de Estado, e o Estado os transmite principalmente por meio da TV Escola.

Em meados dos anos 60, ainda que a EAD fosse principalmente difundida por programas de rádio, iniciou-se a produção e transmissão de cursos de EAD televisionados, que foram impulsionados por iniciativa do

\footnotetext{
${ }^{6}$ Fontes: João Vianney et alii, 2003; Pretto, Nelson de Luca, 1994; Franco, Marília da Silva, 1987.

${ }^{7}$ Exame de Madureza, certificações pelas SEED e atualmente ENCCEJA.
} 
governo, principalmente pela criação, em todo o Brasil, das televisões educativas.

Em 1964, o MEC reservou 48 canais VHF e 50 canais UHF para implantação delas. No Rio Grande do Sul, em 1965, foi criado o SERTE (Serviço de Rádio e Televisão Educativos); já em 1967 foram criadas no Rio de Janeiro a FUNTEVÊ (Fundação Centro Brasileiro de Televisão Educativa que incorpora a atual TVE-RJ), e em São Paulo a TV Cultura, que só iniciou suas atividades em 1969. Também em 1969 surgiu a TVE-MA, oferecendo TV educativa em canal fechado, mas rapidamente migrando para sinal aberto em 1970. Em 1970, em São Paulo, a TV cultura iniciou suas atividades de transmissão lançando o Telecurso Madureza Ginasial, sendo essa a primeira série educativa criada pela Fundação Padre Anchieta. A TVE-MA, em 1970, ofereceu Teleducação para todas as séries do $1 .^{\circ}$ Grau em sinal aberto.

O projeto SACI (Satélite Avançado de Comunicações Interdisciplinares), um convênio entre MEC, CNPq e INPE, foi planejado entre 1967 e 1968, e teve início em 1972, atingindo o Nordeste do país, utilizando o sistema de transmissão por satélite, inicialmente capacitando supervisores e professores, e em 1973 com oferta de aulas pré-gravadas para alunos das séries iniciais e professores leigos do Ensino Primário do Rio Grande do Norte. A TVE-Ceará teve início em 1974 , veiculando as tele-aulas de $5^{\mathrm{a}}$ a $8^{\mathrm{a}}$ séries do $1 .^{\circ} \mathrm{Grau}$, atuando tanto com a EAD, quanto como apoio ao ensino presencial.

A partir dos anos 70, a iniciativa privada também passa a produzir audiovisuais para EAD, atendendo suas demandas particulares e seus interesses. O SENAC, em 1976, criou o Sistema Nacional de Teleducação, um núcleo do próprio SENAC de atividades EAD, com cursos em caráter 
experimental na área de aprendizagem comercial. Em 1995, a Rede Nacional de Tecnologia, constituída pela Confederação Nacional da Indústria e Serviço Nacional de Aprendizagem Industrial (CNI/SENAI), criou o projeto INFOVIA, que oferecia a seus integrantes serviço de Internet, videoconferência e TV corporativa, estruturados num sistema via satélite e por meio de cabos de fibras ópticas terrestres.

Em 1994, surgiu a TV SENAC, utilizando transmissão por satélite, privada e codificada, realizando teleconferências e videoconferências, posteriormente em associação com canais comunitários universitários. Com distribuição de programação cultural, reciclagem profissional, e de interesse de aprendizagem na área do comércio, também se utilizava a interatividade durante os programas televisionados, por meio de fax, telefone e e-mail para contatos.

Em setembro de 1997, foi criado o Canal Futura, canal educativo privado de iniciativa da fundação Roberto Marinho, que conta com o apoio e patrocínio da Rede Globo de Televisão (TV Globo), Confederação Nacional da Indústria (CNI), Confederação Nacional do Transporte (CNT), Federação das Indústrias do Estado de São Paulo (FIESP), Federação das Indústrias do Estado do Rio de Janeiro (FIRJAN), Serviço Brasileiro de apoio às Micro e Pequenas empresas (SEBRAE), Fundação Vale do Rio Doce (FRVD), Fundação Bradesco, Fundação Itaú Social, Grupo Gerdau, Grupo Votorantim, BayerSchering Pharma e Turner Broadcasting - CNN. O Canal Futura transmite programação educativa e profissionalizante; tendo iniciado sua transmissão por meio de TV por assinatura (Multicanal, Net e Sky, posteriormente também na GNT e DirecTV), já em 1998 passou a transmitir também em TV aberta, e hoje 
conta, ainda, com recepção digital aberta por meio de antenas parabólicas na banda $C^{8}$.

O Canal Futura propõe-se como uma resposta ao desafio de contribuir para a formação educacional da população, atuando na educação da criança, do jovem, do trabalhador e de toda a sua família.

\section{A criação das TV's Universitárias trouxe para os cursos superiores o} desafio de produzir audiovisuais e também de repensar os programas de EAD.

Em 2000, foi lançado o PUC-Virtual, programa de educação a distância da Pontifícia Universidade Católica, implementado por duas de suas unidades, uma em Minas Gerais (Belo Horizonte) e outra no Rio Grande do Sul (Porto Alegre), as quais lançaram programas próprios de educação a distância, com uso de multimídias, entre eles TV universitária, videoconferências e produção de material multimídia.

Ao longo desse período, por um lado vemos tanto a EAD como a utilização dos audiovisuais ampliar seu espectro de atuação, inicialmente restrito à alfabetização do público leigo analfabeto e adulto ${ }^{9}$; gradualmente, elas passam a atuar em capacitações específicas para um público já

\footnotetext{
${ }^{8}$ Sintonia digital por antena parabólica: polarização vertical 20 (Fonte: Sítio eletrônico oficial do Canal Futura).

${ }^{9}$ Em 1961, uma associação entre a TV-Rio e a Fundação João Batista do Amaral veiculou o curso à distância de "Alfabetização de Adultos". Em 1970 o projeto MINERVA, com ênfase na educação de adultos, reuniu cerca de 63 emissoras de TV, veiculando conteúdos para preparação para exames do Supletivo de Capacitação Ginasial e Madureza Ginasial. Em 1971 surgiu a primeira Telenovela Educativa, pela TVE-RJ, intitulada "João da Silva", para alfabetização de adultos, a qual foi ao ar entre 73 e 74 com cerca de 100 capítulos e ainda 25 aulas retrospectivas, 10 programas complementares e 5 livros de apoio. Perpassando os anos 70, 80, 90 e 2000, registram-se as diversas formatações do Telecurso 1. ${ }^{\circ}$ Grau da Fundação Roberto Marinho e Fundação Padre Anchieta.
} 
escolarizado, como os professores do $1 .^{\circ} \mathrm{Grau}^{10}$, passando ao ensino de $2 .^{\circ}$ Grau e Ensino Profissionalizante ${ }^{11}$, chegando por fim ao Ensino Superior ${ }^{12}$.

Apesar de os audiovisuais passarem a ser incorporados aos níveis mais elevados da educação, é importante observar que isso não significou um amadurecimento em relação ao emprego da linguagem audiovisual no ensino; pelo contrário, nesse mesmo período há um empobrecimento dos elementos da linguagem audiovisual presentes nos audiovisuais educativos. Enquanto, no início, buscava-se experimentar o potencial da linguagem audiovisual, por meio da gravação de aulas, criação de seriados educativos até a realização de telenovelas educativas, pensando os usos da linguagem audiovisual para a educação, hoje os audiovisuais estão, em sua maior parte, restritos à gravação de aulas e videoconferências; não exploram os elementos pré-lógicos dessa linguagem, tampouco são planejados para a fruição.

Esses audiovisuais tentam aproximar-se do discurso da razão em detrimento da emoção, e é por isso que apresentam menor rejeição, sendo aceitos até mesmo no Ensino Superior, enquanto os audiovisuais de entretenimento continuam sendo sub-utilizados e, na maioria das vezes, seu potencial educativo é desprezado.

Há exceções que merecem destaque, pois se apropriam do potencial da linguagem audiovisual para educar e têm sido utilizadas em sala de aula; por

\footnotetext{
${ }^{10}$ Em 1962 a associação entre a TV-Rio e a Fundação João Batista do Amaral veiculou o curso à distância de "Aperfeiçoamento de Professores Primários". Entre 1974 e 1976 a Telescola, projeto da TV Cultura e Fundação Padre Anchieta, em parceria com a Secretaria de Educação do Município de São Paulo, teve como finalidade apoiar as disciplinas de Ciências e Matemática do Curso Ginasial.

${ }^{11}$ Em 1994, juntamente com o Telecurso 2000, a Fundação Roberto Marinho, em convênio com a Federação da Indústrias do Estado de São Paulo, também lançou o Telecurso Profissionalizante de Mecânica. Esses dois projetos contavam com programas de televisão e coleções de fascículos para preparação de alunos candidatos à realização de exames supletivos e de certificação profissionalizante

${ }^{12}$ Em 1978, pela primeira vez, instituições de ensino superior constituíram um centro de teleducação, no Rio Grande do Sul, criando-se o Centro de Teleducação do Sul (CITES-MEC). Em 2000, PUC-Virtual, programa de educação a distância da Pontifícia Universidade Católica, utilizou a TV Universitária, videoconferências, entre outros recursos.
} 
exemplo, a série de animação "De onde vem" da TV Escola, mini-séries de caráter histórico, como "A casa das Sete Mulheres", e seriados de divulgação científica como "O mundo de Beakman".

O papel de destaque dado pelo Governo Federal aos audiovisuais na EAD reforça a premência de aprofundarmos as pesquisas sobre a linguagem audiovisual e o ensino, já que se tem incentivado a realização de produtos audiovisuais para os vários níveis de ensino ${ }^{13}$.

O mais abrangente programa brasileiro de inserção do audiovisual na educação já está vigorando há mais de uma década, a TV Escola, lançada pelo Governo Federal em setembro de 1995, visando equipar as escolas públicas de todo o Brasil com kits tecnológicos ${ }^{14}$ de recepção e gravação de programas televisionados via satélite, em sinal aberto, captado por antena parabólica ${ }^{15}$. 0 canal entrou em operação em março de 1996, aproveitando programações já existentes, como a série "Um Salto para o Futuro", no ar desde 1991, que ainda hoje faz parte de sua programação, entre outros. Para estimar a abrangência da TV Escola, em levantamento feito em 1999, constatou-se que 56 mil escolas públicas já tinham instalados seus kits tecnológicos.

Hoje a TV Escola é um programa da Secretaria de Educação a Distância, do Ministério da Educação, dirigido à capacitação, atualização e aperfeiçoamento de professores da Educação Básica. Ela transmite 24 horas de programação diária, com repetições, de forma a permitir às escolas diversas opções de horário para gravar os conteúdos audiovisuais. A programação

\footnotetext{
${ }^{13}$ A programação da TV Escola divide-se em cinco categorias: Educação Infantil, Ensino Fundamental, Ensino Médio, Salto Para o Futuro e Escola Aberta.

${ }^{14} \mathrm{O}$ kit tecnológico é composto por televisor, videocassete, antena parabólica e receptor de sinal.

${ }^{15}$ Sintonia Analógica: Polarização Horizontal; Número do Transponder: 3; Freqüência: $3.770 \mathrm{MHz}$. Sintonia digital: Polarização Vertical; Freqüência: Banda C; Transponder: 7B; E: 397175 L: 1178,25 FCE 2/3; Symbol Rate: 04028457 (Fonte: Sítio eletrônico da TV Escola, no portal do MEC).
} 
mensal e a veiculação dos programas estão disponíveis ao professor através de uma grade mensal, que é recebida de forma impressa nas escolas e também pode ser acessada pela Internet no sítio da TV Escola ${ }^{16}$.

Sua programação, bastante diversificada, destaca-se por veicular uma pluralidade de audiovisuais, que possibilitam explorar a linguagem de muitas maneiras, o que permite ao professor utilizar o potencial educativo dessa linguagem. A programação percorre animações, filmes, seriados, documentários, videoconferências, entre outros. Ela veicula produtos audiovisuais de produção nacional e também internacional. A multiplicidade de olhares que é propiciada pela programação veiculada pela TV Escola permite uma reflexão sobre o papel do audiovisual na educação de forma ampla e consistente.

A maior dificuldade que identificamos em utilizar o material está principalmente no fato de que muitos dos programas já veiculados no passado não são reapresentados, como é o caso de "O mundo de Beakman", que já esteve presente na grade e hoje não é mais veiculado pela TV Escola. Nesse sentido, a TV Escola apresentou duas soluções complementares que resolvem parcialmente o problema: em primeiro lugar, a produção especificamente realizada para a TV Escola está disponibilizada para os professores no sítio eletrônico da TV Escola. A segunda ação foi a criação do DVD Escola, uma coleção de DVD's com a programação realizada para a TV Escola, que é distribuída e incorporada ao acervo das escolas.

\footnotetext{
${ }^{16}$ Sítio oficial do MEC/SEED no endereço

http://portal.mec.gov.br/seed/index.php?option=content\&task=view\&id=66\&Itemid=
} 
Não houve solução para a programação veiculada pela TV Escola, que não foi realizada especificamente para ela, entre eles os filmes e vídeos produzidos no exterior.

Também há os projetos de iniciativa dos governos estaduais para a capacitação docente, os quais se utilizam da EAD e, atualmente, são apoiados principalmente na interatividade das mídias digitais e em videoconferências ou teleconferências. Nesses casos, o emprego do audiovisual é restrito e a linguagem audiovisual fica descaracterizada de sua essência emotiva. Vejamos, no âmbito do estado de São Paulo, alguns desses projetos que se destacam por sua abrangência.

Em 2001, surgiu o Programa de Educação Continuada (PEC) Formação Universitária, iniciativa da Secretaria de Estado da Educação, do Governo do Estado de São Paulo, em parceria com a USP (Universidade de São Paulo), UNESP (Universidade Estadual Paulista "Júlio de Mesquita Filho") e PUC-SP (Pontifícia Universidade Católica).

O projeto teve como principal objetivo oferecer aos professores da rede pública estadual, que possuam apenas o Ensino Médio (com habilitação em Magistério), um programa superior de licenciatura, com duração de dois anos. Eram realizadas teleconferências e videoconferências. As diversas videoconferências tinham o acompanhamento de trabalhos presenciais sob orientação de um professor tutor.

Em 2002, foi realizado o Programa de Educação Continuada (PEC) Construindo Sempre, programa de capacitação e aperfeiçoamento de professores PEB II (Professores de Educação Básica II) da Rede Estadual de Ensino de São Paulo, com o apoio de mídias interativas, promovido pela 
Secretaria de Estado da Educação, para atender a professores que atuam no Segundo Ciclo do Ensino Fundamental e no Ensino Médio. O programa, desenvolvido junto à USP, por intermédio da Fundação de Apoio à Faculdade de Educação - FAFE, possibilitou aos professores o conhecimento e a utilização de diversas modalidades de mídias interativas. Realizaram-se uma videoconferência e diversos trabalhos para capacitação nas mídias interativas, os quais tiveram o acompanhamento presencial de um tutor para cada turma e um professor orientador para cada duas turmas.

Em maio de 2003, foi inaugurada a Rede do Saber, uma rede pública de videoconferências com finalidade pedagógica, a qual visa a capacitação em serviço e acompanhamento do desenvolvimento dos profissionais da educação, de forma permanente. Foi baseada na ampliação da infra-estrutura criada para o PEC, estendendo-a a todos os profissionais que compõem os quadros da SEE-SP.

A Rede do Saber caracteriza-se por um conjunto articulado de dispositivos técnicos e metodologias capazes de criar um sistema de comunicação e de trabalho interativo de largo alcance, apoiada em recursos de teleconferência, videoconferência, ambientes de colaboração virtual pela Internet, ferramentas administrativas, de gestão e de educação, com suporte de tecnologias de informação e comunicação.

Em 2004, o programa de formação continuada "O Ensino Médio em Rede", destinado aos assistentes técnico-pedagógicos (ATP's), supervisores de ensino, professores coordenadores (PC's) e professores de Educação Básica nível II atuantes no Ensino Médio regular, contou com o uso dos ambientes de aprendizagem e os recursos virtuais da Rede do Saber: 
teleconferências, videoconferências e ferramentas da Web, além de materiais de apoio especialmente desenvolvidos para o programa. A segunda fase do Programa, desenvolvida em 2006, deu ênfase ao desenvolvimento curricular específico no Ensino Médio, incluindo a área de Ciências da Natureza, Matemática e suas Tecnologias. Segundo as estimativas, por estar apoiado em processos desenvolvidos pela Rede do Saber, promoveu uma formação em cadeia que atingiu cerca de 60 mil agentes educacionais ${ }^{17}$.

Destaca-se entre os projetos da SEE-SP o Educom.TV, realizado em 2002, pois buscou trazer à tona a reflexão sobre a linguagem audiovisual e seu potencial para o ensino. A parceria do Núcleo de Comunicação e Educação da Escola de Comunicação e Artes (ECA) da USP, GIP/FDE e Secretaria da Educação do Estado de São Paulo, promoveu um curso a distância de capacitação da utilização da linguagem audiovisual em sala de aula, para professores da rede estadual.

Participaram 2200 professores-cursistas da rede e 35 professorestutores da Universidade, além da equipe operacional e os docentes da Universidade responsáveis pela organização e implantação do projeto. Utilizando-se a mídia digital, houve atendimento on-line, correção de exercícios e de projetos educomunicativos de utilização de audiovisuais no ensino, além de quatro encontros presenciais, nos quais foram organizadas oficinas sobre linguagem audiovisual e educomunicação.

A programação da TV Escola foi utilizada nesse projeto, como base para as atividades relacionadas aos cursos de Ensino Fundamental e de Ensino Médio. Também foram discutidas e realizadas oficinas que buscavam

\footnotetext{
${ }^{17}$ Dados obtidos do GTE da Fundação Vanzolini, envolvida no projeto http://portal.vanzolini-ead.org.br/default.aspx?SITE_ID=167\&SECAO_ID=1082
} 
disseminar formas de se apropriar de filmes, telenovelas, programas de auditório, comerciais para televisão, na educação, juntamente com a proposta de desenvolver na escola a formação do espírito crítico sobre o emprego da linguagem audiovisual em nossa sociedade.

Essa iniciativa diminuiu o preconceito sobre a utilização da linguagem audiovisual em sala de aula, apresentando aos professores opções para utilizar a programação televisiva em suas aulas, e também realçou o potencial dos audiovisuais educativos realizados especificamente para o ensino disciplinar. Iniciativas como essa ainda estão por serem realizadas em escala nacional; é preciso tratar a formação docente com o mesmo empenho com que o governo tem tratado a aquisição de bens e de materiais.

Também é necessário resgatar a produção de audiovisuais para a divulgação da Ciência, os quais efetivamente se apropriem da linguagem audiovisual, desenvolvendo os argumentos de cunho científico por meio da emoção e do entretenimento, devolvendo o sabor e a emoção do conhecimento; é nesse sentido que a linguagem audiovisual tem muito a contribuir com a escola. 


\section{Os audiovisuais no ensino de Física}

No Brasil os primeiros audiovisuais realizados para o ensino de Física foram os filmes educativos do INCE, produzidos entre 1936 e 1961. No final dos anos 50 e nos anos 60 os filmes de entretenimento e de divulgação científica de Walt Disney ensinavam conceitos científicos e propiciavam fruição ao espectador, divertiam e educavam tratando de temas da Física, como a energia nuclear.

A partir da década de 60 , passaram a ser importados filmes educativos vinculados aos projetos de ensino de Física, os primeiros deles foram filmes do projeto norte-americano PSSC (Physical Science Study Committee). Posteriormente, nos anos 70 , os projetos brasileiros de ensino de física passaram a produzir filmes para inseri-los como estratégia de ensino. Nos anos 80 e 90, a produção de audiovisuais para a TV e as produções distribuídas em videocassete passaram a subsidiar os projetos de ensino, e no final dos anos 90, com as transmissões via satélite, as teleconferências e videoconferências passaram a ter grande destaque entre os audiovisuais utilizados na educação.

Nos anos 2000 a Internet de banda larga, com grande capacidade de transmissão de dados, o barateamento dos computadores potentes e as inovações tecnológicas trouxeram para os professores recursos equivalentes aos da videoconferência, como o MS Messenger ou mais complexos, como elearning - os ambientes virtuais de aprendizagem. Hoje a velocidade de transmissão de dados, os programas de edição de imagens e os instrumentos de captação de imagens tornaram-se tão acessíveis, que muitos vídeos 
amadores com argumentos relacionados à Física podem ser encontrados em sítios eletrônicos como YouTube, LifeVideo ou DailyMotion.

\section{Um breve histórico}

Começaremos essa história nos anos 30, com a produção dos filmes de curta-metragem produzidos no Brasil pelo INCE. Trata-se de uma produção pautada pela exploração do conteúdo científico por meio da linguagem cinematográfica, produzindo-se filmes nos quais a fruição se apresenta como um elemento fundamental, sendo possível identificar nessas realizações consistência na linguagem do cinema. Trata-se de um cinema educativo que não é monótono e, por isso, é mais educativo ainda.

"Em 1936 dá-se o grande e histórico encontro do cinema brasileiro com a educação. Humberto Mauro realiza em seis meses, 28 filmes, totalizando 150 minutos sobre temas que vão de taxidermia a passos de dança.... quando completa 78 anos e comemora 50 de dedicação ao cinema Brasileiro, Mauro termina seu filme educativo de número 228." (Franco, 1987, p. 29)

No período de 1936 a 1947 foram produzidos pelo INCE cerca de 38 filmes de divulgação técnica e científica e 34 filmes de pesquisa científica nacional, 23 filmes preventivo-sanitários, 16 filmes sobre atividades econômicas, 5 filmes escolares, 16 filmes-reportagens, 4 filmes sobre o meio rural, muitos dos quais abordando temas científicos ${ }^{18}$.

Entre os filmes que discutem Ciência, a encenação é recorrente e obedece em geral a uma estrutura que tem uma linha de continuidade pontuada por peças musicais clássicas - essa estrutura pode ser resumida em

\footnotetext{
${ }^{18}$ Fonte: Catálogo de filmes produzidos pelo INCE in: Schvarzman S., Humberto Mauro e as imagens do Brasil , 2004 e Franco, Marilia da Silva, Escola audiovisual, 1987.
} 
uma introdução com narração didática de cunho histórico e locução grandiloqüente, seguida do desenvolvimento do argumento com enfoque prioritário do assunto, sem presença do técnico ou do cientista que se faça notar; o sujeito do filme é o argumento, seja ele uma alavanca, uma balança etc.; a conclusão, em muitos desses filmes, tem como apelo a esperança, tanto na trilha musical como em sua narração, finalizando-se com imagens bucólicas, como o céu com nuvens, ou de esperança, como crianças sorrindo (Schvarzman, 2004, p. 250-259). Dentre esses filmes, "O Céu do Brasil no Rio de Janeiro" buscava reproduzir por meio da animação de um planisfério ${ }^{19}$ os "efeitos de um planetário" no cinema e chegou a participar do Festival de Veneza de $1938^{20}$.

"... o filme introduz o espectador às estrelas por meio de mapas concebidos por Manuel Pereira Reis, professor da Escola Politécnica, e a enumeração de constelações que a câmera não particulariza, até que aparece o Cruzeiro do Sul, estrela descoberta e assim denominada, segundo o filme, pelos navegantes portugueses por conta de sua luminosidade invulgar. Essa excepcionalidade da constelação que brilha e orienta $o$ firmamento nacional introduz a descrição do céu no dia da Independência e da Proclamação da República. O trajeto do Cruzeiro do Sul, que configura a 'Hora da Pátria' no dia 7 de Setembro e 'o céu da bandeira nacional' no dia 15 de Novembro, termina impresso nas imagens de estrelas de uma bandeira

\footnotetext{
${ }^{19}$ Equipamento constituído por dois discos concêntricos, um com o mapa celeste anual para uma latitude, sobreposto por outro cuja janela permite que ao ajustar a data e o horário se identifique a configuração das estrelas no céu em determinada longitude, como na carta celeste. O movimento da carta celeste corresponde ao das estrelas no céu, mas não espacialmente como faz o planetário.

${ }^{20}$ Schvarzman S., Humberto Mauro e as imagens do Brasil , 2004, p. 254.
} 
nacional tremulando ao som do Hino à Bandeira." (Schvarzman, 2004, p. 253-254)

A experimentação proposta ao tentar representar por meio do filme o movimento das estrelas, buscava reproduzir o que faz um planetário, dava ao céu o papel central no filme, mostra como o cinema de Humberto Mauro tratava os argumentos científicos pelo olhar da câmera, pela linguagem audiovisual.

Entre os filmes produzidos pelo INCE $^{21}$ destacamos aqueles cujo argumento está diretamente ligado à Física. Em 1936: "A medida do tempo", "Máquinas simples - Alavancas", "Máquinas simples - Roldanas, plano inclinado e cunha", "Um parafuso", "Medida de massas - Balanças", "O telégrafo no Brasil", "Barômetros", "Manômetros", "Ar atmosférico", "Microscópio composto" e "O Céu do Brasil na Capital da República". Em 1937: "O Céu do Brasil no Rio de Janeiro", "Hidrostática - Propriedades e equilíbrio de líquidos", "Medida de comprimento", "Magnetismo", "Planetário" e "Eletrificação da Estrada de Ferro Central do Brasil". Em 1938: "Laboratório de Física na escola Primária" e "Talha". Em 1939: "Serviços de Esgoto do Rio de Janeiro - Fundição", "Propriedades elétricas do Puraquê" e "O Puraquê - peixeelétrico - Prof. Carlos Chagas Filho". Em 1940: "Da força hidráulica à Energia elétrica". Em 1942: "Mecânica geral", "Montagem de motor”, “Trefilação", "Fabricação de pregos, parafusos e porcas" e "O coração físico de Ostwald". Em 1944: "Motor elétrico", "Penetração de rádio-iodo na tireóide pelo Prof. Carlos Chagas F. e Dr. Eduardo de Robertis", "Eletrômetro Capilar", "Pulso Capilar" e "O segredo das asas - FAB - poema de Maria Eugênio Celso". Em 1946: "Princípios fundamentais do microscópio eletrônico", "Fabricação de

\footnotetext{
${ }^{21}$ Não tivemos aceso aos filmes, utilizamos a filmografia e os relatos presentes em Schvarzman S., Humberto Mauro e as imagens do Brasil, 2004 e de Franco, Marilia da Silva, Escola audiovisual, 1987.
} 
ampolas" e "Farol". Em 1947: "Heliotipia - processo Roquette-Pinto" e "Cristal oscilador - Industrialização do quartzo no Brasil". Em 1948: "O mundo eletrônico" e "Salinas - Cabo Frio". Em 1950: "Eclipse". Em 1953: "Lentes oftálmicas - Indústria" e "Refração ocular - Correção Visual - fabricação de lentes". Em 1954: "Nem tudo é aço". Em 1961: "O Papel - História e fabricação".

Por se tratar de curtas-metragens, os filmes restringem seu argumento a poucos ou apenas um conceito, tratando de temas fundamentais na Física, como a massa, o tempo, o espaço, o magnetismo, a eletrificação; também discutem aplicações científicas e tecnológicas como alavancas, talhas, telégrafos, motores, lentes ópticas; processos e transformações são retratados em temas mais abrangentes como a usina hidrelétrica, as salinas, a heliotipia etc. A preocupação com instrumentos de medidas está presente mesmo quando se discutem os temas fundamentais como a massa (balança), a medida do tempo, além dos filmes cujo argumento é o equipamento de medida, como barômetro, manômetro, microscópio. O interesse pela Astronomia é destacado e desenvolvido em temas como eclipse, o céu e planetário.

Embora muitos desses filmes pudessem ser utilizados no ensino da Física, e alguns deles diretamente relacionados ao ensino da Física, como "Laboratório de Física na escola Primária" de 1938, não foram encontrados, em nossa pesquisa, indícios ou registros de que tenham sido utilizados com essa finalidade nos projetos de ensino de Física no Brasil.

\section{Década de 1960}

A partir da década de 60 passaram a ser importados filmes educativos, vinculados aos projetos de ensino de Física, o que pode ser observado 
analisando os diversos projetos de ensino de Física traduzidos para o português e a inserção dos audiovisuais neles. No Brasil, o primeiro projeto a utilizar o audiovisual como estratégia de ensino foi o projeto norte-americano PSSC (Physical Science Study Committee), traduzido na década de 60. Os filmes apresentavam diversas funções dentro da proposta: havia filmes para introdução de um assunto, filmes para auxiliar, resumir e integrar alguns conhecimentos e filmes que demonstram experimentos de difícil execução num laboratório.

Em cada filme produzido, um pesquisador realiza uma atividade associada à Física, seja ela num laboratório experimental, seja ela teórica na construção e interpretação de equações e gráficos, seja ela histórica.

Os filmes produzidos em película e em preto e branco são bastante diferentes dos filmes do INCE. Têm maior duração, entre vinte e trinta minutos, trazem maior quantidade de conceitos e muitas informações, a fala do pesquisador é dirigida ao espectador e as imagens ilustram as falas. Esses filmes não trazem emoção, são lineares e monótonos e não há trilha sonora, também não há uma preocupação com a contextualização nem com a problematização do argumento desenvolvido; em alguns filmes como "Energia e trabalho" há uma pequena introdução nesse sentido. Alguns deles com versão em português são: "A velocidade da luz no ar e na água", "Pressão da luz", "Momento angular", "Energia e trabalho", "Conservação de energia", "Eventos aleatórios”, “A experiência de Millikan”, "Energia mecânica e térmica”, "A dilatação do tempo", "A massa do elétron"22.

\footnotetext{
${ }^{22}$ Exemplares desses filmes, telecinados e armazenados em fitas de videocassete podem ser encontrados no Instituto de Física da Universidade de São Paulo.
} 
Na mesma época em que o PSSC era traduzido, foi produzido no Brasil, por um grupo internacional de professores, organizado pela UNESCO, o Projeto Piloto para o Ensino da Física, cujo primeiro tema, e único desenvolvido, foi "Física da Luz", que teve uma versão em português e uma versão em espanhol. Esse foi um projeto de ensino auto-instrutivo, baseado em tecnologia da educação, e produziu e utilizou, além de um filme sonoro ${ }^{23}$ de 16 $\mathrm{mm}$, onze loops ${ }^{24}$ de $8 \mathrm{~mm}$ e também uma série de oito programas para TV aberta $^{25}$, incorporando-a como um meio instrucional ${ }^{26}$.

O filme em película, em preto e branco (um média-metragem), problematiza e busca responder à questão "Luz é onda?". O cientista, professor Paulus A. Pompéia, da Universidade, leva duas crianças em idade escolar para os laboratórios da Universidade e juntamente com eles faz experimentos de difração para mostrar o efeito com ondas na água, ondas sonoras, ondas de rádio e ondas de luz.

O filme inicia-se com dois ciclistas colidindo numa esquina, pelo motivo de um não ver o outro a tempo de evitar a colisão; depois, o filme mostra a mesma situação, com os ciclistas usando o som de da buzina antes de chegar à esquina e conseguindo, com isso, prevenir a colisão. A partir daí o professor leva os dois ciclistas (um menino e uma menina em idade escolar) para o laboratório da Universidade para entender porque o som pode ser escutado mesmo sem que se consiga enxergar sua fonte. Os diálogos estão restritos às

\footnotetext{
${ }^{23}$ O filme sonoro "Luz é onda?” do projeto piloto Física da Luz , foi telecinado e armazenado em fita de videocassete e pode ser encontrado no acervo do Instituto de Física da Universidade de São Paulo.

${ }^{24} \mathrm{O}$ filme-loop trata-se de um filme em película com as extremidades unidas. Ele roda dentro de um cartucho e pode ser exibido continuamente sem a necessidade de trocar a posição do rolo de filme, daí o nome filme-loop, que retorna ao início e recomeça.

${ }^{25}$ Não encontramos registros de que a série para TV tenha sido veiculada no Brasil.

${ }^{26}$ Ver Dib, Cláudio Zaki, 1972.
} 
falas entre os personagens e não são dirigidos em momento algum ao espectador.

\section{Década de 1970}

Em oposição à tradução e adaptação de propostas internacionais de ensino de Física, surgiram na década de 70 os projetos nacionais de ensino de Física. Um deles é o projeto Física Auto-Instrutiva (FAl), que também utiliza a tecnologia da educação associada à auto-instrução e propõe a utilização de audiovisuais com fins "eminentemente motivacionais", tendo produzido dois filmes com essa finalidade: "O pêndulo" e "Laboratório sem fronteiras - sem paredes", tendo também incentivado a utilização de outros audiovisuais, já existentes, com a mesma finalidade ${ }^{27}$.

Nesse mesmo período, o Projeto de Ensino de Física (PEF) propôs um ensino experimental da Física e, segundo seus autores ${ }^{28}$, opôs-se à produção e utilização de recursos audiovisuais, uma vez que os audiovisuais disponíveis do PSSC não eram utilizados por falta de equipamentos nas escolas e por não ter sido dublados, existindo, além disso, poucas películas disponíveis. Esse projeto tinha como base a elaboração de um material que fosse de fácil aquisição; o audiovisual foi renegado devido às dificuldades técnicas presentes à época.

O Projeto Brasileiro para o Ensino de Física (PBEF) encontrou outra solução para o problema descrito pelos autores do PEF, e incorporou audiovisuais com a utilização de diafilmes, uma simplificação do filme; exibe-se uma coleção de 20 a 40 diapositivos associada a um texto, que pode ser gravado e reproduzido, ou mesmo lido em voz alta pelo professor durante a

\footnotetext{
${ }^{27}$ Ver Daher, Fuad Saad, 1977.

${ }^{28}$ Ver Bittencourt, Diomar da Rocha Santos, 1977.
} 
exibição das imagens. A equipe do PBEF produziu um diafilme como alternativa ao cinema didático sob o tema "A energia que recebemos do Sol". Um dos autores desse projeto também produziu alguns filmes, que não tinham relação direta com o projeto, mas que foram utilizados intencionalmente nele ${ }^{29}$.

No Instituto de Física da USP, na década de 70, surge um grupo de filmes didáticos, que realiza filmes educativos não associados a projetos de ensino de Física. Para a produção desses filmes foi firmado um convênio entre duas instituições: Instituto de Física (IF-USP) e Escola de Comunicação e Artes (ECA-USP), e por meio desse convênio participaram dessa produção professores de Física e professores de Cinema, sendo utilizado para essa produção o equipamento cinematográfico da ECA-USP ${ }^{30}$.

Foram produzidos dezesseis filmes em película, coloridos e mudos, com pequena duração (3 minutos, aproximadamente), destinados ao ensino no $1 .^{\circ}$ ano básico da Universidade ${ }^{31}$. Neles, tanto o encadeamento linear de imagens, como a trucagem para inserção de efeitos especiais e a inserção de legendas, tornam o desenvolvimento do argumento claro e possibilitam o entendimento de conceitos abstratos, como o movimento do centro de massa (CM), mesmo sem utilizar o recurso de áudio.

A série "Centro de massa" estuda o movimento do centro de massa de um sistema material, sendo composta por oito filmes: "Sistemas Rígidos Movimento quando a resultante das forças externas é nula", "Sistemas Rígidos - Relação entre a matemática e o experimento", "Movimento do CM de

\footnotetext{
${ }^{29}$ Ver Caniato, Rodolpho, 1973.

${ }^{30}$ Ver Muramatsu, Mikiya, 1976.

${ }^{31}$ Exemplares desses filmes, telecinados e armazenados em fitas de videocassete podem ser encontrados no Instituto de Física da Universidade de São Paulo.
} 
sistemas não rígidos", "Explosão", "Choque", "Centro de massa de sistemas deformáveis (A)", e "Centro de massa de sistemas deformáveis (B)".

A série "Colisões" estuda a conservação do momento e da energia nas colisões, sendo composta por cinco filmes: "Colisões elásticas unidimensionais", "Colisões elásticas bidimensionais", "Colisões inelásticas unidimensionais", "Colisões inelásticas bidimensionais" e "Energia interna nas colisões".

A série "Energiômetro" apresenta a construção e calibração de um medidor de energia através de dois filmes: "Energiômetro 1 - Projeto" e "Energiômetro 2 - Calibração". Foi realizado ainda o filme "Impulsão"32.

Na década de 70 , os filmes de um só conceito, como os realizados nesse convênio, foram bastante difundidos no ensino de Física, impulsionados pela tecnologia de películas de $8 \mathrm{~mm}$, com o barateamento da produção de filmes e a simplificação no manuseio dos equipamentos (Muramatsu, 1976, p. 7).

\section{Década de 1980}

Nos anos de 1980, a inovação tecnológica trouxe uma nova "epidemia audiovisual" às escolas. Dessa vez os videocassetes e as televisões eram introduzidos no ensino; "todas as escolas" foram equipadas com esses aparelhos.

Essa tecnologia não precisava de um técnico especializado, mas também não apresentava tanta facilidade quanto se imaginava no início, porquanto hoje já temos 20 anos dessa tecnologia e ainda há muitos

\footnotetext{
${ }^{32}$ Não foram localizados nos acervos de audiovisuais da Universidade de São Paulo exemplares da série "Energiômetro” e do filme “Impulsão”.
} 
professores que não sabem operar esses equipamentos, muito menos instalálos e conectá-los corretamente.

Os projetos de ensino à distância, como o "Telecurso $1 .^{\circ}$ Grau" e o "Telecurso 2. ${ }^{\circ}$ Grau", da Fundação Roberto Marinho, veiculados até 1994, o “Telecurso 2000" (Ensino Fundamental e Ensino Médio), veiculado até 2006, e o "Novo Telecurso" (Ensino Fundamental e Ensino Médio) veiculado atualmente, utilizam amplamente os recursos audiovisuais no ensino da Física.

Os vídeos (tele-aulas) apresentam uma visão geral da Física, em seus campos de estudo clássico e moderno, com títulos como: "O mundo da física", "Acelera Brasil!", "Tudo que sobe, desce", "Empurra e puxa", "Eu tenho a força! Será?", "Por que não flutuamos?", "Chocolate, energia que alimenta", "O trabalho cansa?", "Conservação, o "x" da questão", "Estou com febre?", "Águas passadas não movem moinho!", "Dá um tempo, motor!", "Como uma onda no mar...", " Um papinho, um violão e a bendita construção", "Assim caminha a luz", "Eu não nasci de óculos", "Alta voltagem", "Deu curto!", "Hoje não tem vitamina, o liquidificador quebrou!", "O mundo do átomo", "Mergulhando no núcleo do átomo", "Tudo é relativo".

Os vídeos (tele-aulas) do telecurso $2000^{33}$ buscam introduzir o conhecimento físico por meio de diálogos entre personagens em diversos ambientes urbanos, como uma banca de jornal, a cozinha de um restaurante, o interior de um apartamento, a saída de um shopping center etc. Também há personagens que representam os "cientistas": os monitores da Estação Ciência trazem explicações mais específicas sobre o argumento e vestem jalecos, o que reforça a diferenciação dos demais personagens. Os vídeos fazem

\footnotetext{
${ }^{33}$ Ao todo em Física foram realizados 49 tele-aulas, com cerca de 30 minutos de duração cada.
} 
referência ao material escrito, os livros do telecurso, que devem ser consultados para mais esclarecimentos sobre o tema que está sendo desenvolvido no vídeo.

Também houve projetos que, ao proporem discutir o ensino em geral, discutiram em específico o ensino da Física, como o projeto IPÊ (1985), cujo enfoque formativo de promoção de cursos de aperfeiçoamento de professores de $1 .^{\circ}$ e $2 .^{\circ}$ Graus contava com programação regular na TV Cultura, e após 1990 passou a ter também um foco nos conteúdos disciplinares.

A Física foi contemplada pelo projeto IPÊ, imersa na área de Ciências, e contou com três episódios: "Do fogo às reações Nucleares", "A energia num Mundo em Crise", "A dinâmica do Universo". Os audiovisuais são ricos em sons e neles há inserção de animações, trechos de filmes, entrevistas, explorando de forma plural os elementos da linguagem audiovisual. Posteriormente o projeto IPÊ deu origem ao canal TV Escola ${ }^{34}$.

Nos anos 90, o projeto de ensino de Física do Grupo de Reelaboração do Ensino de Física (GREF), com mais de uma década de existência, também incorporou a utilização de recursos audiovisuais e produziu programas para TV aberta em cooperação com a TV Cultura $^{35}$. Os temas abordados: "Movimentos", "Controle de calor", "Luz e cores", "Energia elétrica e sua geração", "Ondas eletromagnéticas" e "Ferramentas", correspondem a conjuntos de conhecimentos desenvolvidos nos materiais didáticos formulados pelo GREF. Os programas televisionados, em cores, foram veiculados pela TV Cultura de São Paulo e pela TV Escola e tinham formato jornalístico. Iniciavamse com uma reportagem que contextualizava o argumento desenvolvido no

\footnotetext{
${ }^{34}$ Ver Vianney et al, 2003.

35 Programas realizados pela SEED-SP e Fundação Padre Anchieta/RTC-SP para veiculação na programação ligada à TV Escola, veiculada pela RTC-SP.
} 
audiovisual, passando em seguida ao desenvolvimento por meio de entrevista com um professor do GREF. Cada programa discutiu situações cotidianas em que os princípios físicos eram explorados e também realizaram demonstrações das atividades experimentais propostas nos textos do GREF. Foram incorporados neles alguns trechos de audiovisuais produzidos em 1991 para o projeto IPÊ.

\section{Década de 1990}

Outro programa que, ao propor a discussão do ensino em geral, discutiu em específico o ensino da Física, surgiu em 1991: o "Salto para o Futuro", que desde 1996 faz parte da grade diária da TV Escola. Com proposta de formação continuada de professores de Ensino Fundamental e Médio, veicula também séries de interesse para a Educação Infantil. É um programa ao vivo, on-line e interativo, e tornou-se referência formativa para professores e educadores de todo o país, utilizando diferentes mídias como TV, Internet, fax, telefone e material impresso, no debate de questões relacionadas à prática pedagógica e à pesquisa no campo da educação.

O programa conta hoje com orientadores educacionais que coordenam os trabalhos em aproximadamente 800 telepostos, distribuídos em todo 0 território brasileiro, e tem momentos interativos que possibilitam aos professores, reunidos nesses espaços, um contato "ao vivo" com os debatedores dos temas em análise. Assim, como no projeto IPÊ, a Física comparece no ensino de Ciências; por exemplo, na série "Iniciação científica: um salto para a ciência", foram realizados cinco programas com foco no desenvolvimento continuado de atividades de iniciação à Ciência nas escolas, 
a fim de debater e provocar mudanças na prática pedagógica do ensino de Ciências na educação básica.

Por fim, por volta do ano 2000, tivemos uma nova "epidemia audiovisual" nas escolas, associada a outra inovação tecnológica: o uso das antenas parabólicas e dos receptores de satélite, associado aos videocassetes e TV cujo embrião foi gerado em 1987 - já estava presente na idealização do $1 .^{\circ}$ Encontro Brasileiro de Educação e Televisão ${ }^{36}$.

Foram criados canais de TV específicos para a divulgação de programas educativos, voltados às escolas. Os programas televisionados são transmitidos via satélite para todo o País e podem ser gravados e guardados no acervo da escola para utilização em sala de aula. Projetos da iniciativa pública, como a TV Escola (1995), e da iniciativa privada, como o Canal Futura (1997), são dessa natureza e apresentam produção e veiculação de programas educativos, entre outros, programas ligados ao ensino de Ciências e também especificamente ao ensino da Física.

A TV Escola veiculou muitos audiovisuais cujo argumento se relaciona à Física. Dentre animações, seriados, filmes, videoconferências, realçamos a série de animação "De onde vem?" da TV Escola ${ }^{37}$, que abordou temas como energia elétrica, raio e trovão, onda, arco-íris, o dia e a noite, princípios de funcionamento do avião, da televisão, da produção do sal, papel, plástico e vidro. Com linguagem apropriada para o público infantil, as curiosidades da menina Kika despertam o interesse também de adolescentes e de forma

\footnotetext{
${ }^{36}$ Em 1986 a comissão interministerial entre Ministério da Educação e Ministério da Comunicação, portaria 390/86, foi contrária à proposta do INEP/MEC de elaborar um encontro para ampla discussão sobre o uso de satélites para fins educacionais. Então em 1987 o INEP e a FUNTEVÊ realizaram um encontro amplo discutindo Televisão, rádio e educação. Ver Pretto, 1994, p. 112-113.

37 Toda a série (20 animações) pode ser encontrada para download no sítio http://www.dominiopublico.gov.br
} 
divertida os educa. Após uma introdução contextualizada no cotidiano, a menina levanta questionamento sobre o argumento da animação; por exemplo, em "De onde vem o avião", num aeroporto, ela, aguardando o tio que chega de viagem, pergunta de onde vem o avião. A utilidade dos aviões na sociedade é seguida por um breve histórico sobre a criação do avião por Santos Dummont, seguido pelo princípio do funcionamento da turbina, e por fim é explicada a função da asa no vôo do avião. São mescladas à animação filmagens que ajudam a desenvolver o argumento. A animação encerra-se com a menina Kika recapitulando os principais conceitos, geralmente numa fala rimada e ritmada. Esse audiovisual tem duração de quatro a cinco minutos, é rico em sons e possui trilha sonora.

A TV Escola também veicula os programas realizados para o projeto IPÊ e para o "Salto para o Futuro", já mencionados; além disso, os programas da série "Sala de Professor" apresentam debates e uma proposta de utilização de um audiovisual da TV Escola por uma equipe de três docentes, realizando-se um trabalho contextualizado e interdisciplinar a partir do audiovisual. Episódios de séries importadas, como "Ciência Nua e Crua 2" da BBC da Grã-Bretanha, são utilizados para trabalhos interdisciplinares entre Física, Matemática e Química ${ }^{38}$; os da série “As conseqüências da Revolução Industrial”, também da BBC, para interdisciplinaridade entre Física, Sociologia e História ${ }^{39}$; os de produção nacional, como a série "O Mundo da Fotografia", são usados para um trabalho interdisciplinar entre Física, Matemática e Biologia ${ }^{40}$.

\footnotetext{
38 Título: A Ciência da comemoração. Série: Ciência Nua e Crua 2, BBC. Grã-Bretanha, 2002.

39 Título: Criando maravilhas. Série: As consequencias da revolução industrial, BBC. Grã-Bretanha, 2003.

${ }^{40}$ Título: Macrofotografia. Série: O mundo da Fotografia, STV. Brasil, 2000/2002.
} 
A TV Escola também veiculou a série educativa "O mundo de Beakman", que é utilizado em nossa pesquisa por apresentar a Ciência de forma prazerosa, por se apropriar dos elementos da linguagem audiovisual de forma a promover um vídeo educativo em que se valoriza a fruição.

A programação mensal e os títulos dos programas ficam disponíveis para o professor através de uma grade mensal que é recebida previamente na forma impressa nas escolas e também pode ser acessada pela Internet no sítio eletrônico da TV Escola.

\section{Década de 2000}

A fim de ampliar a atuação da TV Escola, em 2004 o Governo Federal investiu no projeto DVD Escola, que passa a usar uma mídia física como o DVD para gravar os programas da TV Escola e enviá-los às escolas que não possuem o kit tecnológico da TV Escola. O programa já atendeu a cerca de 80 mil escolas no país ${ }^{41}$.

“O Projeto DVD Escola integra um conjunto de políticas e ações do Ministério da Educação cujo foco é garantir a universalização, o elevado padrão de qualidade e a eqüidade da educação básica no Brasil. O Projeto sinaliza, também, o compromisso com a atualização tecnológica e democratização da TV Escola, uma vez que o acervo e os modernos aparelhos de DVD alcançarão escolas públicas ainda não atendidas. ...."

“... Foram adquiridos e serão enviados a 50 mil escolas públicas de ensino básico um aparelho de reprodução de DVD e

\footnotetext{
${ }^{41}$ Fonte SIGETEC - no endereço eletrônico - http://sip.proinfo.mec.gov.br/relatorios/pub_resultados.php
} 
uma caixa com 50 mídias DVD, contendo, aproximadamente, 150 horas de programação produzida pela TV Escola." 42

A distribuição do acervo da TV Escola é uma iniciativa importante para que ele seja utilizado nas escolas, pois supera o problema de formar o acervo, já que em muitas escolas ainda não é possível realizar um acervo completo, por falta de material e de pessoas qualificadas que realizem a seleção por meio da grade de programação, tenham disponibilidade de horário para estar na escola no dia e hora em que seja exibida a programação, além de ter de desempenhar todas as atividades para as quais foi contratado para atuar na escola.

O acervo atual conta com 100 mídias DVD com cerca de 300 horas de programação. Em Física podemos realçar, além dos temas já apresentados ao discutir a TV Escola, a série "Mundo da Ciência", realizada pelo Canal Futura, com 600 minutos de programação, com destaque para temas como "Lâmpada e Espelho", "Efeito Eletro-Estático e Lâmpada Fluorescente", "CCO - Metrô de São Paulo e Raio Laser", dentre os 60 programas, cada um com 10 minutos de duração, sempre abordando dois temas. Também realçamos o programa "Com Ciência - Ensino Médio" ${ }^{43}$, produzido pela TV Escola, que apresenta soluções implementadas em escolas que buscaram inovar seu currículo, destacando-se os temas "Física Moderna" e "Radio Escola", específicos do ensino da Física.

Com o barateamento dos aparelhos de DVD e das técnicas de gravação para essa mídia, muitos outros produtos audiovisuais estão sendo remasterizados e distribuídos em DVD, inclusive os mais antigos: por exemplo,

\footnotetext{
42 Trechos extraídos do sítio eletrônico oficial do DVD Escola, no portal do MEC.

43 Toda a série "Com Ciência" (12 temas) pode ser encontrada para download no sítio http://www.dominiopublico.gov.br
} 
a série "Cosmos" (1980-1981), de Carl Sagan, lançada em DVD pela revista Super-Interessante no ano de 2005.

Com o avanço da rede mundial de computadores e do acesso à Internet por banda larga com maior velocidade, programas e arquivos que antes só podíamos imaginar em grandes servidores, hoje trafegam entre computadores pessoais. Compactadores cada vez mais potentes promovem a redução dos tamanhos dos arquivos de imagens e sons, o que determinou um avanço significativo na distribuição, assim como a circulação de audiovisuais na rede se tornou mais intensa.

Com o uso de listas e fóruns de discussão, de plataformas de aprendizagem, de sítios eletrônicos de relacionamentos, de programas de mensagens em tempo real, da conectividade on-line da Internet, a interatividade tomou um papel importante na sociedade virtual moderna.

No caminho da interatividade, o uso de audiovisuais das mais diversas naturezas teve presença marcante, principalmente na educação a distância; inúmeros programas que descrevemos anteriormente abordaram especificamente conteúdos disciplinares da Física, como o Programa de Educação Continuada (PEC) - Formação Universitária (2001), o projeto Educom.TV (2002) do Núcleo de Comunicação e Educação da Escola de Comunicação e Artes (ECA) - USP, o Programa de Educação Continuada (PEC) - Construindo Sempre (2002), o Ensino Médio em Rede (2006).

Mesmo em projetos comerciais, como o Vestibulando Digital, a interatividade está fortemente presente: após a programação diária da série, ficam à disposição do estudante professores on-line para tirar dúvidas e ajudar 
no entendimento de aspectos do material nos quais o estudante sinta dificuldade.

A programação da TV Escola também utiliza bastante a interatividade, principalmente nas videoconferências e nos programas da série "Salto para o Futuro", em que os professores assistem ao programa e podem fazer perguntas aos debatedores, tecer comentários, tudo via Internet, telefone e fax.

A Rede do Saber também se caracteriza pela interatividade, sendo um conjunto articulado de dispositivos técnicos e metodologias capazes de criar um sistema de comunicação e de trabalho interativos de largo alcance, com o apoio de recursos de teleconferência, videoconferência, ambientes de colaboração virtual pela Internet, ferramentas administrativas integradas de gestão e educação, com suporte de tecnologias de informação e comunicação.

Dessa forma, temos possibilitado ao produto audiovisual estabelecer um novo grau de interatividade entre os protagonistas e os espectadores, o que passa a ter a maior relevância, neste momento em que chega ao Brasil a nova geração de televisores digitais, que traz entre seus avanços a interatividade, numa comunicação de duas vias.

As inovações na área de informática, como a Internet de banda larga, os programas de edição de imagens, e os recursos de captação de imagens por webcam ou por câmeras fotográficas digitais, disponibilizaram aos professores novos recursos audiovisuais.

Há recursos equivalentes aos da videoconferência, como o MS Messenger, ou mais complexos, como o e-learning - os ambientes virtuais de aprendizagem, que podem ser utilizados em tempo real (on-line). A produção amadora de vídeos para a Internet com baixa resolução veicula na maioria das 
vezes o material bruto capturado por imagens de câmeras paradas, por isso destituídas de uma estrutura que explore a linguagem audiovisual, principalmente por desconhecimento dessa linguagem.

Essa produção, ao mesmo tempo que democratiza a produção de uma cultura audiovisual popular, torna emergente a necessidade de discutir os elementos dessa linguagem, explorando-a em seu potencial educativo. Muitos vídeos amadores com argumentos relacionados à Física podem ser encontrados em sítios eletrônicos como YouTube, LifeVideo ou DailyMotion.

Dada a variedade de audiovisuais à disposição dos educadores que trabalham com o ensino da Física, bem como as múltiplas formas de expressão que podem ser encontradas pelo uso dessa linguagem, que percorre desde filmes mudos, passando por animações e filmes comerciais, audiovisuais educativos e de entretenimento, audiovisuais amadores, além de novas formas de interatividade das mídias digitais, das videoconferências e da internet, tornase mais importante identificar na prática pedagógica da escola, nas salas de aula, quais audiovisuais estão presentes e como eles estão colaborando para uma educação imersa no novo paradigma, em que a linguagem audiovisual não é mero coadjuvante da expressão verbal, assumindo ela seu papel na construção de novas formas de pensar, sobretudo com sentimento e emoção.

Hoje, na sala de aula, quais são os audiovisuais utilizados pelos professores? Quais as formas de interatividade que a escola tem oferecido aos alunos? Que estímulo a escola dá à realização de audiovisuais pelos alunos?

Quais contribuições os professores têm dado às escolas para que elas se insiram no novo paradigma? Quais contribuições as escolas têm dado a 
seus professores para que eles possam imergir no novo paradigma? Qual a participação dos alunos em todo esse processo?

Estas são algumas perguntas em aberto que merecem a atenção dos agentes educacionais em seus diversos níveis hierárquicos, as quais sem dúvida precisam de respostas; mas não basta apenas às escolas e aos professores buscar maior familiaridade com essa linguagem e explorar o potencial educativo em suas aulas, reconhecendo-se na diversidade de audiovisuais à sua disposição aqueles que contemplam seus anseios ou aqueles que Ihes propõem desafios. É preciso também que o Estado implemente novos programas de desenvolvimento da Educação, pautados no novo paradigma, e que contribuam para sua evolução. 


\section{Os audiovisuais na pesquisa em ensino de Física}

Está provado que só é possível filosofar em alemão Se você tem uma idéia incrível

É melhor fazer uma canção

Está provado que só é possível

Filosofar em alemão

Blitz quer dizer corisco

Hollywood quer dizer Azevedo

E o recôncavo, e o recôncavo, e o recôncavo

Meu medo!

(Caetano Veloso, 1984, Língua)

Nos versos de Caetano não há deboche de nossa língua materna, e tampouco a desqualificação da importância da música como forma de expressão cultural. Neles se expressa de forma irreverente a relação entre pensamento e linguagem, a qual é retratada em referenciais teóricos como os de Vygotsky ou de Pierce.

Essa imbricada relação entre pensamento e linguagem tem sido investigada nas pesquisas em ensino de Física e tem posição de destaque no entendimento do papel do audiovisual no ensino.

\section{A construção de significado: um processo dinâmico}

Buscando uma visão crítica para o uso do audiovisual na educação, na literatura encontramos pesquisas cuja finalidade foi identificar e conhecer algumas leituras que os alunos realizam de um vídeo didático de Física.

As características específicas da linguagem audiovisual, como seus signos - que em parte são a fusão de signos de outras linguagens, 
transformados numa nova estrutura mais complexa, híbrida, plural, em que simultaneamente diferentes estímulos dos sentidos promovem a produção de significado - permitem que ao mesmo tempo sejam recebidos múltiplos estímulos que podem se reforçar ou mesmo se contrapor uns aos outros.

Essa linguagem cria uma nova forma de pensamento na qual as leituras realizadas permitem um enorme leque de interpretações, contrapondo-se à visão ingênua de que ler corresponde a extrair do texto algo pronto, acabado e único (Lopes, 1995).

A leitura, entendida como a produção de significado para o texto, num processo contínuo e plural, contribui para o entendimento das transformações potencializadas pela relação simbiótica entre pensamento e linguagem, em seu aspecto mediador entre o homem e a realidade natural e social. Dessa forma explicita-se que o sentido não existe em si, ele é ideológico e determinado por relações sociais e históricas (Lopes, 1995).

As relações que produzem sentido podem ser criadas e transformadas a partir de diferentes relações estabelecidas entre signo, significante e significado, num processo dinâmico e de construção de sentido (Miléo, 1994).

Em pesquisa sobre a leitura que se faz do vídeo, realizada por Lopes, identificou-se essa pluralidade de significados construídos nas leituras dos alunos, e mostrou-se que há diferença entre a leitura que o aluno faz do vídeo e a leitura feita pelo professor. A pesquisa mostra que os alunos se apropriaram dos conhecimentos trazidos pelo audiovisual, elaborando suas leituras por caminhos diferentes dos propostos pelo vídeo didático. A descrição de que o vídeo tem como argumento a luz e utiliza análogos mecânicos para explicar os fenômenos que ocorrem com ela, corresponde à leitura do 
professor, mas difere da leitura realizada pelos alunos, registrada no instrumento de pesquisa. Para os alunos, os fenômenos luminosos eram os análogos utilizados para explicar os fenômenos mecânicos, construindo uma trajetória oposta àquela intencionada pelo professor e proposta pelo audiovisual (Lopes, 1995).

Como vemos, o aprendizado é dinâmico e é um processo de construção de significado, por isso não é possível pensar em "recepção passiva", quando se discute o emprego de audiovisuais no ensino; não existe o conhecimento em si, pois é na apropriação do conhecimento e em sua transformação que ele adquire significado. Esse entendimento é corroborado hoje por referenciais teóricos da comunicação, como Martín-Barbero, os quais identificam que a comunicação não é algo pronto emitido pelo emissor, ela depende do receptor e trata-se de um processo de construção.

$\mathrm{Na}$ sala de aula isso se traduz na relação que se estabelece com o aluno, pois ele não faz mera decodificação da informação: ele transforma a mensagem a partir de sua interação com ela, de seus mecanismos de produção de significado. É necessário conhecer o repertório dos alunos, suas concepções alternativas, daí a importância de atuar na vertente de pesquisa em conhecimentos espontâneos (Lopes, 1995). Também é preciso se contrapor à forma "ingênua" de utilizar audiovisuais em sala de aula, a qual aliena o audiovisual de seu potencial transformador e educativo, restringindo-o a uma atividade que não é integrada ao currículo escolar (Franco,1987).

Devemos buscar incorporar os audiovisuais às salas de aula explorando seu papel educativo e transformador, com a finalidade de promover a diversidade de leituras, estimular a construção dinâmica de conhecimento, 
social, que ocorre coletivamente, revelando que o conhecimento é ao mesmo tempo processo e produto da cultura humana; se por um lado a cultura pode ser materializada num produto audiovisual, por outro lado, o audiovisual é um instrumento cultural que permite a exploração do mundo e sua transformação, caracterizando-se dessa forma como bem de produção; assim se expressa sua dupla natureza, em seu potencial educativo e transformador.

\section{As funções do audiovisual no ensino da Física}

Uma questão importante para o ensino da Física é determinar as funções que os audiovisuais podem desempenhar nele. Nesse sentido são igualmente importantes os papéis que historicamente foram desempenhados e a proposição de novos papéis que venham a ser desempenhados.

É possível constatar que não são muitos os professores que utilizam sistematicamente audiovisuais em sala de aula (Pretto, 1994; Miléo, 1994), e seu uso pode ser resumido em quatro finalidades: para introduzir um assunto; para ilustrar; como reforço ou revisão; e para relaxar, sendo utilizado em lugar da aula (Miléo, 1994). Esses empregos dados aos audiovisuais acabam apenas por redundar o conhecimento e não correspondem à formação de novos conceitos num processo interativo. Eles divergem da proposta de um novo paradigma da educação o qual incorpore os meios audiovisuais em seu potencial transformador.

Para que se explore adequadamente seu potencial transformador, podemos recorrer ao emprego do audiovisual numa prática dialética da educação, a qual consiste na apresentação de um problema para que os 
alunos busquem soluções, partindo dos conceitos cotidianos dos alunos, passando por conceitos trazidos por meios como os audiovisuais, textos, o professor etc. (Miléo, 1994); e, após contrastar os diversos conceitos, elaborar conclusões que deverão ser apresentadas aos demais alunos, demonstrandose a codificação. Assim, os alunos podem construir ativamente o conhecimento na interação com os audiovisuais.

É possível identificar em pesquisas realizadas no ensino de Física alguns problemas que dificultam o uso do audiovisual, como a falta de divulgação e distribuição dos filmes didáticos e a falta de espaços físicos adequados (Muramatsu, 1976), os quais até hoje ainda não foram superados; mesmo com a implementação da TV Escola, que difunde diversos filmes, não se estabeleceu uma divulgação eficiente e tampouco se adotou um mecanismo de distribuição que incentive o uso desse recurso; assim, a afirmação de que "é ainda remota a possibilidade de utilizar filmes em educação em larga escala no Brasil" (Muramatsu, 1976, p.38) permanece válida até hoje.

Para superarmos esses problemas, será necessária a implementação de uma política audiovisual pautada numa prática articuladora entre produção, distribuição, utilização, avaliação e pesquisa (Pretto, 1994), que seja alicerçada nas Universidades e centros formadores de agentes educacionais, para que esteja presente no ensino, na pesquisa e na extensão, de modo que a produção audiovisual seja inserida como instrumento de transformação na formação dos agentes educacionais, e que os centros formadores e Universidades atuem descentralizando a produção (Pretto, 1994) e a distribuição. Os audiovisuais incorporados à formação do professor chegarão 
às salas de aula e poderão ser utilizados numa prática educativa dialógica (Freire, 1974).

Nesse sentido, a produção audiovisual na Universidade passará a desempenhar uma nova função e representar um novo paradigma, que insere a Universidade e os centros formadores no mundo moderno - de imagens, comunicação e informação - e ressignifica o papel do audiovisual didático nela, "uma vez que didático passará a ser seu uso e não o produto em si" (Pretto, 1994, p. 220).

Na Universidade de São Paulo, na década de 1970, estruturou-se um grupo de produção de audiovisuais para o ensino da Física, o qual atuou na realização de filmes no período de 1971 a 1974.

Uma confluência de fatores, como disponibilidade de verbas para produção de material didático no Instituto de Física, o interesse do Departamento de Cinema da Escola de Comunicação e Artes em participar da produção de filmes educativos juntamente com o Instituto de Física, a participação do Prof. Albert V. Baez na orientação inicial desse grupo — permitiu a realização de diversos audiovisuais, em sua maior parte filmes, e entre eles sete filmes didáticos mudos de um só conceito (Muramatsu, 1976).

A produção desse grupo ficou restrita aos anos de 1971 a 1974; nova produção em convênio com a ECA ocorreu em 1998, com a realização do vídeo didático "Fenômenos da óptica geométrica". De forma semelhante, outros núcleos de produção audiovisual nas Universidades realizaram pequenas produções, mas quase não havia vínculo entre eles, nem mesmo entre núcleos de uma mesma Universidade, pois os núcleos normalmente estavam vinculados aos departamentos (Pretto, 1994). 
No Ensino Médio já se configurou um novo papel para a produção de vídeos, em que a participação ativa dos alunos e seu protagonismo se evidenciam. Em geral são ações individuais, mas também ocorrem em cooperação com as Universidades.

Ela começa a ser explorada no ensino da Física como elemento motivador para o aprendizado de conhecimentos científicos na realização de filmes amadores. Ela propicia o aprendizado dos conhecimentos físicos que decorrem da escolha do argumento, da roteirização, do detalhamento dos experimentos montados para serem filmados, da escolha adequada de enquadramentos e da captura das imagens que reforcem características do fenômeno capturado pela câmera (Muramatsu, 1976); assim, os estudantes necessitam aprofundar os conhecimentos físicos relacionados ao argumento.

Há relatos de resultados positivos em trabalhos apresentados pelo grupo de pesquisa do Núcleo de Tecnologia Educacional para a Saúde (NUTES) ${ }^{44}-$ UFRJ, com a produção vídeos por alunos do Ensino Médio.

Essa produção amadora, presente nas escolas ainda de forma incipiente, também está presente na Internet e pode ser encontrada em sítios eletrônicos como YouTube, LifeVideo, DailyMotion entre outros. São vídeos realizados para trabalhos escolares ${ }^{45}$, demonstrações de experimentos ${ }^{46}$, registros pessoais ${ }^{47}$, divulgação de curiosidades $^{48}$ etc. Há também, nesses sítios, audiovisuais elaborados para a divulgação de experimentos científicos

\footnotetext{
${ }^{44}$ Anais do XVI SNEF- Rio de Janeiro, 2005http://www.sbf1.sbfisica.org.br/eventos/snef/xvi/sys/resumos/T0598-1.pdf

${ }^{45} \mathrm{Um}$ exemplo pode ser encontrado em http://www.youtube.com/watch?v=z87hby5XjNQ

${ }^{46} \mathrm{Um}$ exemplo pode ser encontrado em http://www.youtube.com/watch?v=nq3ZjY0Uf-g

${ }^{47} \mathrm{Um}$ exemplo pode ser encontrado em http://www.youtube.com/watch?v=A9p7FGhSPBU

${ }^{48} \mathrm{Um}$ exemplo pode ser encontrado em http://www.youtube.com/watch?v=f2XQ97XHjVw
} 
como aqueles realizados na Estação Orbital Internacional ${ }^{49}$, vídeos institucionais de empresas e de divulgação de tecnologias ${ }^{50}$, entre tantos outros; são audiovisuais que enfocam os princípios físicos. Não encontramos pesquisas sobre esse tipo de produção e suas influências no ensino, mas é um campo promissor para a investigação na área de ensino de Física.

Muitas vezes a produção de audiovisuais educativos visa substituir a atividade experimental em sua finalidade de demonstração (Muramatsu, 1976). Mostrar um fenômeno ou uma experiência, do ponto de vista da linguagem audiovisual, trata-se de um uso restritivo e ingênuo, mas é uma função que se mostra ainda necessária no ensino da Física no Brasil. Muitas são as instituições que não recebem recursos suficientes para aquisição de novos equipamentos de laboratório ou mesmo os recursos necessários para manter em funcionamento seus laboratórios e determinados experimentos. Assim, por meio da realização de filmes que registrem o experimento, os estudantes podem identificar características relacionadas aos fenômenos explorados no experimento, que de outra forma não teriam como conhecer.

Argumentação semelhante a essa pode ser encontrada na literatura para substituir experimentos em muitos outros casos (Miller apud Muramatsu, 1976): como no caso de um experimento que é muito pequeno (câmera de bolhas), ou ao contrário, se o equipamento é muito grande (como num lançamento de foguete); se a experiência é muito lenta (registro do movimento dos planetas em relação às estrelas), ou se ela é muito rápida (ignição de um palito de fósforo); ou ainda se o audiovisual mostrar um evento raro (um eclipse anular) ou se a experiência é perigosa (contém produtos tóxicos, radioativos,

\footnotetext{
${ }^{49} \mathrm{Um}$ exemplo pode ser encontrado em http://www.youtube.com/watch?v=cXsvy2tBJlU

${ }^{50} \mathrm{Um}$ exemplo pode ser encontrado em http://www.youtube.com/watch?v=HjGhxGcKXN0
} 
cancerígenos etc.); e também em experimentos cujos resultados sejam fortemente influenciados por condições locais como temperatura, umidade, quantidade de partículas em suspensão no ar, como é o caso de experimentos controlados em "salas limpas".

Na produção de audiovisuais com essa finalidade, é preciso cuidar para que a captura de imagens e os registros que elas vão apresentar não retratem situações irreais, principalmente no caso de produções amadoras, em que não se fazem presentes os especialistas em Ciência e os especialistas em audiovisuais. Isso se deve ao fato de que a captura não é feita de forma contínua, ela é realizada em quadros ou mosaicos que são coletados de forma discreta, um após o outro, numa determinada freqüência.

Fenômenos ou eventos que ocorram entre um quadro e outro não são registrados, e é por isso que a reprodução da imagem de um helicóptero em vôo pode apresentar as hélices quase estáticas ou com uma freqüência muito menor do que a real ${ }^{51}$, o que não permitiria que ele permanecesse no ar. Nesses casos em que a captura e o registro não retratam o fato com fidelidade, não se pode substituir o experimento, e se faz necessário que os especialistas encontrem soluções que possam permitir a captura e o registro de forma adequada.

É curioso perceber o fato de a captura de imagens ocorrer de forma discreta; se por um lado apresentou-se como um problema num tipo específico de situação, por outro lado tem servido como um instrumento de análise, oferecendo uma nova forma de coleta de dados a partir dos registros presentes em cada quadro capturado (Schiel, 2002).

\footnotetext{
${ }^{51}$ A freqüência que será exibida nos registros depende da relação entre a freqüência de rotação da hélice e a freqüência de captura dos quadros. Fenômeno equivalente a esse ocorre ao filmar a tela de uma TV ou de um monitor de computador.
} 
Essa proposta de utilizar os frames capturados para análise de fenômenos físicos é equivalente à antiga proposta do uso de fotografias estroboscópicas, mas a nova solução ganhou o reforço da capacidade de tratamento computacional ${ }^{52}$.

É possível reconhecer na literatura que recorrentemente as inovações tecnológicas são tomadas como soluções modernizadoras para os problemas da educação (Pretto, 1994). Na década de 1970 o filme-loop era considerado um grande avanço tecnológico, pois se tratava de um único cartucho a ser encaixado no projetor, o que, nesse sentido, facilitava muito a operação, que ainda funcionava com projetores ópticos e com filmes em película dentro do cartucho, mas já disponibilizava o recurso de pausar uma cena, e oferecia-se como recurso para a utilização individual pelo aluno numa filmoteca ${ }^{53}$ (Muramatsu, 1976).

Pode ser difícil entender o que isso representava naquela época, já que isso pode parecer simples para uma geração habituada ao uso pessoal de aparelhos domésticos de reprodução de audiovisuais, os quais têm recursos como avanço rápido, retorno rápido, avanço cena a cena, pausa, busca de capítulos, múltiplos ângulos etc. O filme-loop tem suas duas extremidades unidas, por isso ele se reinicia imediatamente após o seu término, sem necessitar da troca de rolos. O filme dentro do cartucho roda sem parar sendo exibido tantas vezes quantas seja desejado, ininterruptamente, daí o nome de filme-loop, que retorna ao início e recomeça. Hoje a inovação é o DVD, mas até

\footnotetext{
${ }^{52}$ Por exemplo, O CDCC-USP/SC produziu um software para fins educacionais "Sistema Digital para Análise de Movimentos (SAM)" em 1998, gratuito, disponível em http://educar.sc.usp.br/sam/

${ }^{53}$ Segundo Muramatsu, em 1970, no IFUSP a filmoteca tinha cerca de 300 filmes em cartuchos e quase uma centena de filmes $16 \mathrm{~mm}$ sonoro. O catálogo com os filmes está disponível na secretaria do Departamento de Física Experimental (p. 28-29; 44).
} 
uma década atrás era a transmissão via satélite, e antes disso fora o videocassete.

Importante perceber que as inovações tecnológicas não são soluções em si, é preciso superar o mito de que meios instrucionais são capazes, por si sós, de resolver problemas de conteúdos e de metodologia numa sala de aula.

É preciso também superar a rejeição do professor à utilização dos recursos audiovisuais, pois ele também precisa fruir o audiovisual educativo. Nesse sentido, ao divulgar a atuação de Humberto Mauro no INCE, na trajetória do cinema educativo brasileiro (Franco, 1987; Pretto, 1994), podemos ajudar o professor a ver a poesia e a estética da Ciência, o tratamento que traduz o argumento físico em ator do conhecimento, o protagonista de um audiovisual. Também é importante experimentar a irreverência, as emoções que um vídeo didático de entretenimento pode oferecer ao estabelecer um diálogo saudável entre razão e emoção, diálogo que não deveria, jamais, ter-se ausentado da escola.

Ainda estamos por construir o novo paradigma para a Educação que se aproprie das linguagens audiovisuais, e que alimente a necessidade da fruição estética e da motivação afetiva (Franco, 1987), que são elementos motivadores do consumo de linguagens audiovisuais e devem permear todo o ambiente escolar, estabelecendo-se alguns pilares como aqueles propostos por Marília Franco:

"Criar um espaço, na relação mais informal entre professores e alunos, para desenvolver o hábito de debater livremente a matéria audiovisual veiculada no cotidiano. Trazer para a sala de aula as mensagens audiovisuais de veiculação cotidiana, atribuindo-Ihes uma função dentro do conteúdo 
programático das disciplinas. Trazer para a sala de aula produtos audiovisuais produzidos com objetivos culturais, ou mesmo comerciais, projetando-os no espaço de atividade pedagógica, através de filmes ou vídeos. Trazer para a sala de aula produtos audiovisuais realizados com o fim educacional e/ou didático específico" (Franco 1987).

E também propondo novos pilares da atualidade, como trazer para a sala de aula a produção de audiovisuais dentro do conteúdo programático da disciplina; trazer para a sala de aula audiovisuais amadores e debater livremente seus aspectos.

Rever os desafios do passado, perceber que alguns deles foram superados, com o desenvolvimento de novas tecnologias como o DVD ou o videocassete, que possibilitaram superar problemas como a difícil montagem e operação dos equipamentos de projeção de filmes. A facilidade de encontrar audiovisuais em videotecas, vídeolocadoras ou mesmo adquiri-los pela Internet, promoveu a superação da difícil tarefa de identificar as fontes onde se pudesse obter filmes (distribuidoras).

Identificar que novos desafios estão surgindo, como a difícil tarefa de diferenciar realidade e simulação (realidade e ficção). Foi através do desenvolvimento da linguagem audiovisual que criamos o universo virtual, que curiosamente cria oportunidade de empregos reais, lucros e problemas que afetam também a vida real de seus usuários.

Isso pode ser traduzido em fatos quando relutamos em acreditar que não se tratava de ficção a queda das Torres Gêmeas em Nova lorque, ou quando chega a nossa casa a encomenda feita por nosso avatar no Second Life. Na Física isso também transparece quando são utilizados em seu ensino 
os simuladores de experimentos, ou quando os programas espaciais treinam seus astronautas em potentes simuladores. A relevância social dessa questão pode ser revelada no sucesso do filme "Matrix".

Ao utilizar os recursos audiovisuais, é importante que haja um preparo (Muramatsu, 1976; Franco, 1987): é necessário assistir a eles antes de mostrar aos alunos, conhecer guias ou roteiros disponíveis para filmes, estabelecer pontos específicos de interesse, decidir sobre a forma de incorporação deles na aula, verificar elementos que se devam acrescentar na sala de aula como outras informações, propor atividades antes ou após utilizar o audiovisual etc. — estes são alguns procedimentos que permitem explorar melhor os recursos audiovisuais. 


\section{A pesquisa realizada}

A produção de audiovisuais educativos no Brasil cresceu com a implementação da TV Escola, que ainda ocupa papel de destaque na política pública de capacitação docente, por meio da educação a distância. A produção também foi estimulada pela implementação do Canal Futura - o "Canal do Conhecimento", de iniciativa privada, o qual transmite sua programação em sinal aberto.

Essa ampliação da produção de audiovisuais educativos também ocorreu com aqueles destinados ao ensino de Ciências, e em particular ao ensino da Física, o que realçou a importância da pesquisa sobre os materiais audiovisuais no ensino da Física.

A nossa pesquisa procurou investigar, através de vídeos educativos, as características dos meios de comunicação e da linguagem audiovisual que poderiam propiciar um aprendizado da Ciência com melhor qualidade.

\subsection{Delimitando a pesquisa}

Ao analisarmos produtos audiovisuais ligados ao ensino da Física, identificamos uma grande diversidade de materiais desenvolvidos ao longo dos anos e tomamos como parâmetro, para a escolha do objeto de nossa pesquisa, os vídeos educativos veiculados pela TV aberta, fora do ambiente escolar, levando o conhecimento físico às pessoas que tiveram acesso ao produto em sua casa. 
Na mídia televisiva, em canais abertos ao público, no período entre a década de 90 e os anos 2000, no Brasil, inúmeros programas educativos voltados ao ensino de conhecimentos físicos estiveram presentes, entre eles, as séries feitas para a TV, como "Cosmos", "Show da Ciência", "Minuto da Ciência", "Olhando para o céu", "Vestibulando", "Vestibulando Digital", “Telecurso", "Telecurso 2000", "O Professor", "O mundo de Beakman", "Ver Ciência" e "De Onde Vêm?".

Entre os audiovisuais citados, identificamos aqueles que apresentavam conteúdos físicos tradicionais do Ensino Médio, com características instrucionais: "Vestibulando", "Vestibulando Digital", "Telecurso", "Telecurso 2000", além dos que também apresentavam conteúdos instrucionais, porém de forma mais lúdica e prazerosa, como os seriados "O Professor" e "O mundo de Beakman", de grande destaque entre as crianças e os adolescentes na época em que foram veiculados.

Para a pesquisa em sala de aula uma variável relevante foi o recurso material necessário em seu desenvolvimento. Por isso, delimitamos a pesquisa aos vídeos, pois eles ofereciam fácil manuseio e os equipamentos necessários para sua reprodução estavam presentes na maioria das escolas, na sala de audiovisuais ou em carrinhos móveis que podiam ser transportados até as salas de aula, ou permaneciam fixos nas salas de aula.

Entre os audiovisuais com conteúdos físicos tradicionais do Ensino Médio, optamos por realizar a pesquisa com os que abordavam os conceitos científicos com motivação instrucional, mas o faziam de forma lúdica e buscavam trazer uma narrativa e um contexto que fundamentassem as ações. Esses audiovisuais exploravam de forma mais adequada o potencial da 
linguagem audiovisual. Selecionamos para essa pesquisa vídeos das séries "O Professor" e "O mundo de Beakman".

A escolha dos temas abordados na pesquisa ocorreu em duas fases. $\mathrm{Na}$ primeira fase buscamos encontrar, nos dois seriados, episódios que abordassem um tema presente no Ensino Médio regular. Selecionamos o tema "Máquinas simples (alavancas)", tipicamente desenvolvido no Ensino Médio, e que dificilmente acaba sendo tratado no Ensino Fundamental.

Na segunda fase da escolha, ao optarmos por buscar um tema que não fosse usualmente discutido na educação escolar, selecionamos "O princípio de vôo do avião". Nossa intenção ao utilizá-lo na pesquisa era avaliar o potencial desses vídeos fora do ambiente de sala de aula.

Dessa forma, também pretendíamos identificar qual a natureza dos conhecimentos que os vídeos poderiam promover fora do ambiente escolar, como ocorre quando assistem ao episódio televisionado em casa, em espaços não formais de aprendizado, avaliando quanto os espectadores caminhavam na direção do conhecimento científico dos conteúdos abordados, e caracterizando os elementos da linguagem audiovisual que interferiam no aprendizado de Física.

Entre os diversos níveis e modalidades de ensino, optamos por restringir a pesquisa à série inicial do Ensino Médio regular, por entender que os alunos, ao ingressarem no Ensino Médio, estariam mais receptivos a novas experiências, como participar da amostragem da pesquisa.

A opção por instrumentos de pesquisa no formato de pré-teste e pósteste, formulados com questões abertas e situações-problemas, visaram possibilitar ao estudante expressar seu entendimento sobre os conhecimentos 
desenvolvidos no vídeo. As respostas apresentadas pelos alunos aos problemas propostos permitiram inferir o desenvolvimento do conhecimento científico na interação com o vídeo.

Nossa investigação foi pautada inicialmente pelas seguintes hipóteses:

Os quatro vídeos selecionados para a pesquisa tinham elementos diferenciadores tanto em relação à proposta educativa quanto a elementos específicos da produção audiovisual.

Cada episódio adotava soluções diferenciadas para a contextualização do argumento - apenas um deles apresentava uma situação-problema; foi possível, também, diferenciar os seriados que optaram por recorrer a diferentes formas do discurso de áudio, principalmente no que tange à trilha sonora, e diferentes escolhas para o enquadramento.

Era possível desenvolver o conhecimento científico utilizando audiovisuais lúdicos, nos quais a fruição levaria os espectadores ao aprimoramento do conhecimento por meio da linguagem audiovisual.

Por utilizar vídeos que trataram os elementos da linguagem de forma diferenciada, acreditávamos que aquele de que os alunos mais gostassem, e que mais os divertisse, apresentaria melhores resultados no desenvolvimento do conhecimento científico.

O vídeo que contextualizasse o conhecimento e apresentasse uma situação-problema permitiria ao espectador um melhor entendimento do conhecimento científico.

O contexto em que o conhecimento era desenvolvido seria um parâmetro essencial para a construção de significado. Vídeos em que houvesse a proposta de solução de uma situação-problema trariam um melhor 
entendimento dos conhecimentos científicos, por determinarem soluções para problemas reais.

Ao longo da pesquisa, novas hipóteses surgiram em função da análise dos resultados iniciais:

Uma seqüência com dois vídeos de naturezas distintas, que se completam, deveria ter na ordem da apresentação influência sobre a aprendizagem. Nossa hipótese era de que os melhores resultados seriam obtidos pela seqüência que em primeiro lugar apresentasse o vídeo que contextualizasse o conhecimento, e em seguida o vídeo que o sistematizasse, e a inversão da ordem deveria prejudicar o aprendizado.

Os dois pós-testes elaborados para avaliar o desempenho dos alunos depois que eles assistissem aos vídeos eram equivalentes. Como foram elaborados dois pós-testes, um para aplicação após a apresentação de um vídeo, e outro para aplicação após os dois vídeos, os melhores resultados obtidos após a exibição dos dois vídeos poderiam caracterizar-se por diferenças nos pós-testes. Nossa hipótese era que a diferença obtida deveria ser resultado da cooperação entre os dois vídeos, e que os pós-testes eram equivalentes; assim, os melhores resultados obtidos pelos alunos no segundo pós-teste, após a apresentação dos dois vídeos, não se configuravam como vício no instrumento de pesquisa.

\subsection{A seleção dos vídeos e sua caracterização}

Entre os diversos audiovisuais educativos que conhecemos em nossas pesquisas, nos projetos de ensino e na programação de Ciências veiculada nos diversos canais de TV, dois seriados se destacaram no estado São Paulo, nos 
anos 90, por tratar de conteúdos educativos instrucionais de forma lúdica e prazerosa, e por terem participado da grade diária de exibição na TV Cultura.

"O Professor", série realizada para a TV pela Fundação Padre Anchieta, foi exibida na grade diária da TV Cultura (1994), com episódios sobre conhecimentos científicos para a educação básica, muitos deles sobre conhecimentos físicos.

Também veiculado na década de 90 na grade diária da TV Cultura (1995 e 1996), e posteriormente em rede nacional pela TV Record (1997) e pela TV Escola (2001 e 2002), o seriado "O mundo de Beakman", destinado à TV, realizado pela Columbia Tristar Entertainment - USA, dublado em português, apresentava episódios sobre conhecimentos científicos para a educação básica, entre eles os de conhecimentos físicos.

Buscamos nos dois seriados episódios que discutissem o mesmo argumento; assim, escolhemos para o primeiro conjunto de vídeos utilizados na pesquisa o tema "Máquinas simples", com o foco em alavancas, presentes em ambos os seriados; e para o segundo conjunto o tema foi "O princípio de vôo do avião", escolhido buscando-se verificar o aprendizado de conceitos científicos usualmente não abordados no Ensino Médio, como a aerodinâmica.

\subsubsection{Caracterização dos vídeos}

Os quatro vídeos escolhidos para a realização da pesquisa apresentavam diferentes tratamentos para os elementos da linguagem audiovisual $^{54}$ e para a proposta educativa. Eles foram analisados tanto em

\footnotetext{
${ }^{54}$ No anexo 1 são apresentados elementos da linguagem audiovisual e suas características, o que pode contribuir para um melhor entendimento da caracterização realizada para os vídeos selecionados.
} 
relação às características comuns de cada seriado, como às características específicas de cada episódio.

\subsubsection{O Professor}

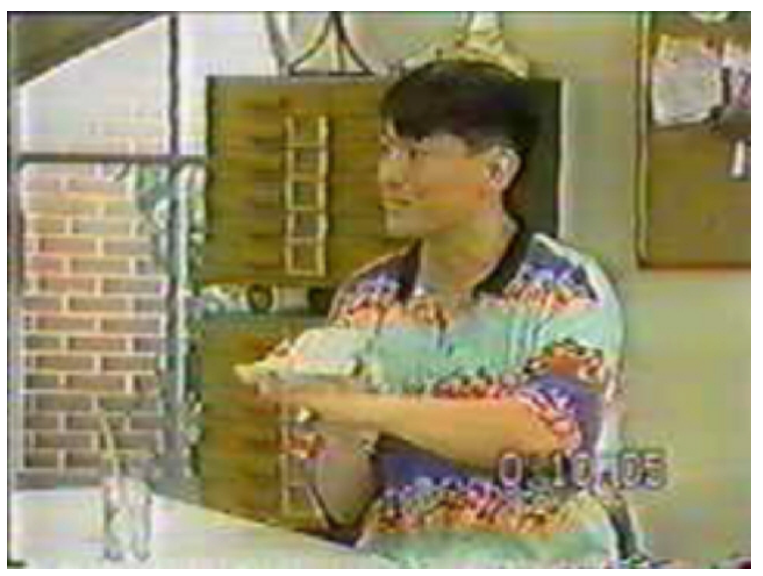

Os vídeos de "O Professor" eram ambientados no interior da casa de um professor, que tinha amigos em idade escolar, adolescentes, que buscavam o amigo para conversar e elucidar perguntas sobre temas de

Ciências usualmente ligados ao cotidiano escolar. O espectador apenas acompanha a conversa e as demonstrações experimentais realizadas pelos protagonistas dos episódios. Não havia muitos sons, o discurso do áudio era basicamente restrito ao diálogo dos protagonistas, havia apenas alguns sons de alerta para chamar atenção para um pensamento ou lembrança, ou para a inserção de um trecho de outro vídeo, ou ainda para o teste final. Quase não havia movimento, a

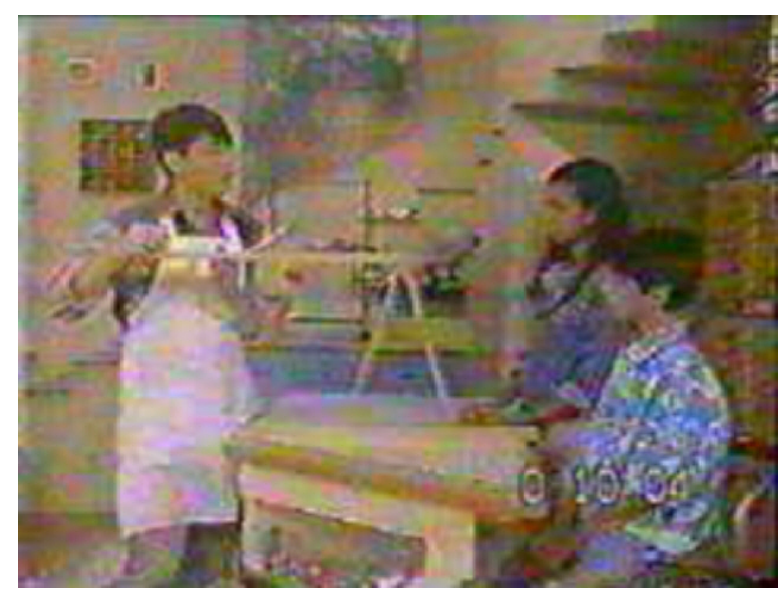
não ser quando ele era necessário para as demonstrações, e na maior parte do tempo os personagens estavam sentados ou parados numa mesma posição em volta de uma bancada.

No episódio sobre alavancas, dois adolescentes buscam a casa do amigo professor, onde iriam almoçar; a conversa deles encaminha-se para que ele explicasse o que são as alavancas. O vídeo tem como argumento as 
alavancas, classificando-as e mostrando vários exemplos do cotidiano, e aborda a questão das relações entre as medidas de distância, entre o apoio e a resistência e entre o apoio e a potência, embora o faça de forma incipiente. Ao final do episódio, no preparo do almoço, o Professor (de origem oriental) faz um almoço típico da culinária japonesa e sugere que eles comam com hashi; então finaliza sua exposição identificando junto aos adolescentes os elementos de uma alavanca presentes na forma de utilizar o hashi para comer. Esse vídeo tem duração de dezesseis minutos e quarenta segundos, com duzentos e vinte e oito planos e duração média de 4,4 segundos/plano. Há o uso sistemático de plano médio e primeiro plano e close; a maioria das mudanças de plano ocorrem em função do diálogo em plano médio e primeiro plano, sendo que closes e planos detalhados são empregados no detalhamento de uma explicação. Nesse episódio foram identificados quarenta e sete planos médios abertos (20\% dos planos), trinta e nove closes (17\% dos planos) e quinze planos detalhados (6\% dos planos).

No episódio sobre o princípio de vôo do avião, uma adolescente que iria viajar de avião para ver sua avó passa na casa do Professor para despedirse dele, e lá encontra aeromodelos montados pelo Professor, que estava utilizando uma bomba spray para repelir insetos. Esses elementos são utilizados no decorrer do vídeo para explicações sobre o princípio de vôo do avião. O vídeo inicia a seqüência de conteúdos com o conceito de pressão atmosférica, seguido pela equação de Bernoulli (fenômeno de Venturi) e explica o funcionamento da asa do avião. Para exemplificar, utiliza o experimento de soprar uma folha de papel e observar que ela se levanta. Em relação à propulsão do avião (hélice e jato), o conceito de ação e reação foi 
utilizado, mas não foi aprofundado. Exemplificou-se o funcionamento da hélice com um ventilador. Utilizou-se também o ventilador para explicar o funcionamento do rotor do helicóptero. Ao final do episódio a menina volta da viagem sem ter andado de avião, pois apesar de entender o princípio de vôo, ela não sabia que era necessário reservar passagens e acabou tendo de ir de ônibus mesmo. Esse vídeo tem duração de vinte e quatro minutos e dez segundos, com trezentos e cinqüenta e dois planos e duração média de 4,1 segundos/plano. A maioria das mudanças de plano ocorre em função do diálogo, principalmente em plano médio. Há o uso sistemático de plano médio e primeiro plano, o close é utilizado no detalhamento das explicações. Nesse episódio são utilizados quarenta e oito planos médios abertos (14\% dos planos), quarenta e sete closes (14\% dos planos) e doze planos detalhados (4\% dos planos).

\subsubsection{2. $\mathrm{O}$ mundo de Beakman}

Os vídeos de "O mundo de Beakman" eram ambientados no interior de

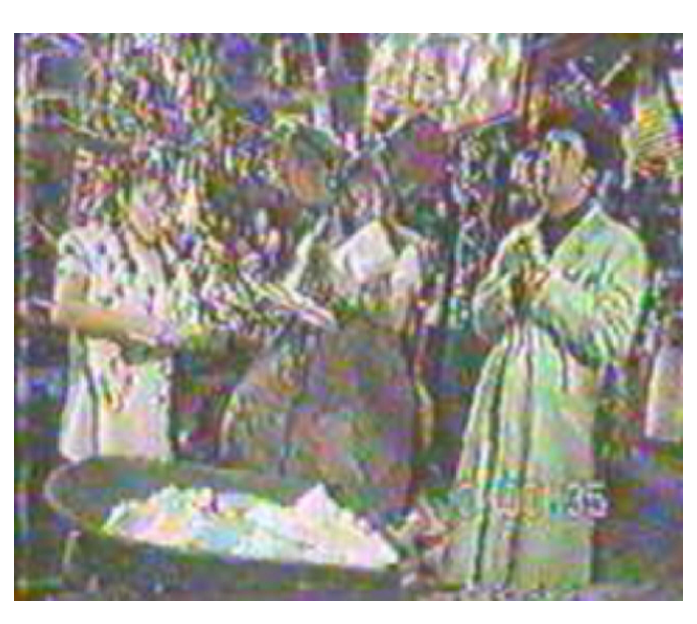
um laboratório, num espaço que era o centro de um depósito de materiais experimentais. Há três personagens principais, o cientista (Beakman), a ajudante e o "Rato de Laboratório", os quais dialogavam ente si e também com o espectador. 
O cientista recebe cartas com pedidos de ajuda para elucidar perguntas sobre temas de Ciências.

O discurso em áudio era rico em música, sons de alerta, chamando a atenção para algum elemento presente no audiovisual, como uma explicação ou a inserção de um personagem, ou de um trecho de outro vídeo, além do discurso verbal dos protagonistas.

Há muito movimento, os personagens movem-se constantemente no cenário e utilizam-se movimentos de câmera como travelling e zoom.

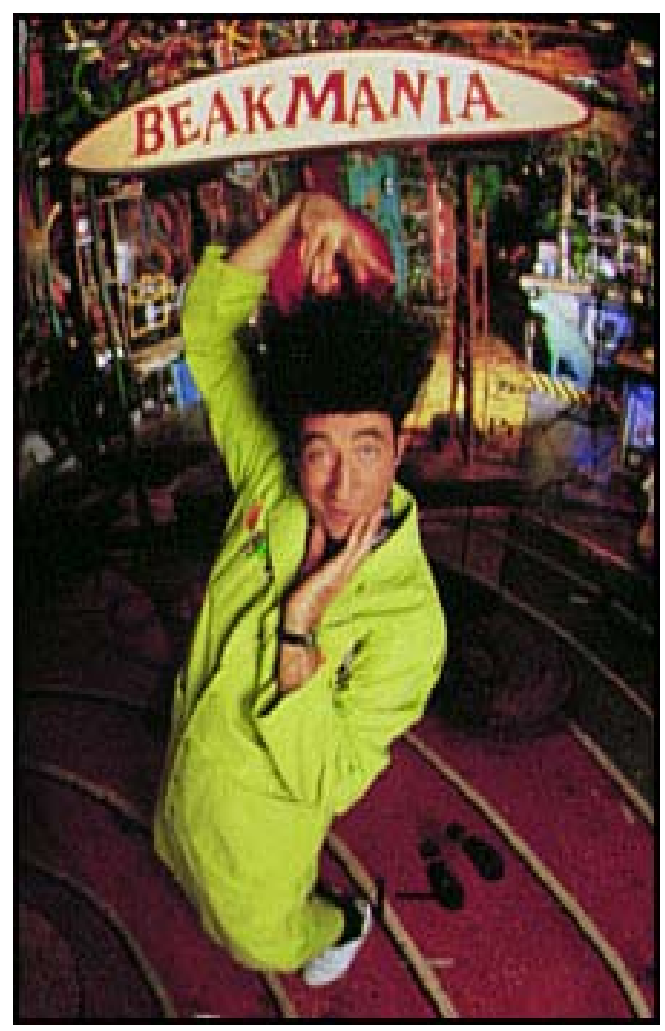

O episódio sobre alavancas inicia-se com a ajudante e o cientista brincando numa gangorra, quando o Rato traz a correspondência. Eles param de brincar para ler a carta, com uma pergunta sobre as alavancas, assunto que uma pessoa estava estudando na escola. O cientista passa a tentar explicar as alavancas de forma simples, quando uma grande pedra cai sobre a gangorra, dentro do laboratório. Eles aproveitam o fato de ter de remover a pedra do laboratório para identificar os elementos das alavancas e utilizá-las para retirar a pedra. Em primeiro lugar usam a gangorra (alavanca de primeiro tipo) para levantar a pedra e colocá-la sobre um carrinho de mão (alavanca de segundo 
tipo), e por fim eles usam uma marreta (alavanca de terceiro tipo) para fragmentar a pedra. Esse vídeo tem duração de oito minutos e um segundo, com sessenta e sete planos e duração média de 7 segundos/plano. Há o uso sistemático de planos de conjunto, plano médio e primeiro plano e close, quase sem uso de plano detalhado. Nesse episódio utilizam-se vinte e seis planos de conjunto (38\% dos planos), nove closes (16\% dos planos) e dois planos detalhados (3\% dos planos). Identificam-se em vinte e três planos (34\% dos planos) cenas em que a fala do cientista foi dirigida diretamente ao espectador.

No episódio sobre o princípio de vôo do avião, o cientista recebe uma carta perguntando por que o avião levanta vôo. O vídeo inicia-se com uma demonstração de que um avião de brinquedo não voa sem as asas. Nesse episódio há a participação do "Homem-Equilíbrio"; esse personagem é um dos disfarces do cientista para ajudar a sua auxiliar, mas ela não o reconhece. A seqüência de conteúdos abordados inicia-se com o conceito de pressão atmosférica, seguindo para a equação de Bernoulli (fenômeno de Venturi), associando-se a força resultante com o gradiente de pressão (que ele chama de "desequilíbrio de pressão") explicando a sustentação promovida pela asa do avião como a "busca" de um equilíbrio. Para exemplificar, utiliza o experimento de soprar uma folha de papel e observar que ela se levanta. A respeito do helicóptero, o vídeo inicia-se com a noção de rotor (asas rotatórias), retomando o princípio de vôo do avião; na seqüência, aborda-se a questão da conservação do momento angular, discutindo-se o papel da hélice na cauda do helicóptero. Esse vídeo tem duração de doze minutos e cinqüenta e seis segundos, com cento e vinte e oito planos e duração média de 6 segundos/plano. Há o uso sistemático de plano de conjunto, plano médio, 
primeiro plano e close. Nesse episódio utilizam-se sessenta e quatro planos de conjunto ( $50 \%$ dos planos), sete closes ( $5 \%$ dos planos) e um plano detalhado (1\% dos planos). Identificam-se vinte e quatro planos (18\% dos planos) correspondentes a cenas em que a fala do cientista é dirigida diretamente ao espectador.

\subsubsection{Comparação entre os dois seriados}

Os dois seriados apresentam uma narrativa linear em que os conceitos são encadeados para construir o conhecimento científico. A interação com o espectador é diferenciada no seriado "O mundo de Beakman", em que há intencionalmente falas dirigidas ao espectador, as quais tentam estabelecer um diálogo com ele, buscam aproximá-lo à trama.

Dos quatro vídeos utilizados na pesquisa, apenas um deles apresenta seu conteúdo disciplinar de forma contextualizada: o vídeo sobre alavancas do seriado "O mundo de Beakman", que se diferencia por apresentar uma situação-problema, na qual uma grande pedra precisa ser retirada do laboratório, utilizando-se alavancas. Os outros três vídeos apresentam respostas a problemas trazidos pelos estudantes e amigos do Professor, ou por cartas, às quais o cientista responde.

O seriado "O Professor" tem uma estrutura bastante parecida com uma aula tradicional; o diálogo, entre os estudantes que fazem as perguntas e o Professor que dá as explicações, dita o ritmo das seqüências de imagens que ilustram as falas, e apresenta uma forma de educação bancária (Freire, 1974). O cotidiano é explorado em exemplos apresentados para ilustrar os conceitos físicos discutidos. 
O seriado "O mundo de Beakman" não se parece com uma aula, apresentando, pelo contrário, a mesma estrutura das séries realizadas para a televisão. O enquadramento em plano de conjunto destaca o constante movimento dos três atores, que quase não ficam parados na tela, andam de um lado para o outro do cenário, dialogam entre si e tecem comentários sobre as falas. O enquadramento privilegia as relações estabelecidas entre os personagens e dá destaque aos conceitos científicos e sua construção. Nesse seriado, o cotidiano pode estar presente como contexto (alavancas) e nos exemplos apresentados. Os personagens tratam com humor o argumento, muitas vezes contrapondo o senso comum ao conhecimento científico.

Em relação aos conteúdos científicos abordados nos dois seriados, é pequena a diferença identificada. Os dois seriados utilizam os mesmos conceitos, e as diferenças presentes estão ligadas ao enfoque dado. Por exemplo, em relação ao princípio de vôo do avião, "O Professor" aborda o princípio de ação e reação na propulsão a jato; já no "O mundo de Beakman" explora-se a conservação do momento angular por meio da função da hélice de cauda no controle do movimento de rotação do corpo do helicóptero.

A maior diferença identificada está no áudio. No seriado "O Professor" o áudio é basicamente restrito aos diálogos, com pequenas inserções de sons de alerta para chamar atenção para a apresentação de um pensamento ou lembrança, para a inserção de um trecho de outro vídeo, ou ainda para o teste final. No seriado "O mundo de Beakman" os sons são explorados de muitas formas, os episódios são ricos em música, sons de alerta, chamando a atenção para algum elemento presente no audiovisual, como uma explicação ou a inserção de um personagem, ou de um trecho de outro vídeo. 


\subsection{As quatro etapas da pesquisa}

$\mathrm{Na}$ primeira etapa da pesquisa, escolhemos um tema relacionado ao Ensino Médio, as alavancas, a fim de investigar e comparar as contribuições que cada um dos vídeos proporciona. Analisamos qualitativamente o conceito físico de alavanca, estabelecendo de quais elementos dos vídeos os alunos gostaram e de quais não gostaram, e delineamos o perfil midiático. Ampliamos a investigação na primeira etapa para verificar que influência poderia ocorrer com a apresentação dos dois vídeos para um mesmo grupo. Para isso foi utilizado o conjunto de dois vídeos sobre máquinas simples, com alunos do $1 .^{\circ}$ ano do Ensino Médio, totalizando 83 alunos, distribuídos em três grupos.

Na segunda etapa foram explorados mais sistematicamente os conceitos físicos, tanto em relação aos conhecimentos espontâneos trazidos pelos alunos quanto aos conhecimentos científicos adquiridos por meio dos audiovisuais; nessa etapa optamos por não aprofundar nossa pesquisa sobre os aspectos da linguagem audiovisual. Reformulamos os instrumentos de pesquisa, passando a utilizar três instrumentos independentes, um pré-teste e dois pós-testes distintos, todos com questões dissertativas. Apresentamos o mesmo conjunto de vídeos sobre máquinas simples para alunos do $1 .^{\circ}$ ano do Ensino Médio, totalizando 64 alunos, distribuídos em dois grupos, classificados em função da ordem em que foram apresentados os dois vídeos.

Na terceira etapa, também elaboramos três instrumentos de pesquisa, mas desta vez sobre os conceitos físicos ligados ao princípio de vôo do avião, um pré-teste e dois pós-testes distintos. Apresentamos um conjunto de dois vídeos sobre o princípio físico de vôo do avião (Aerodinâmica), um do seriado "O Professor" e o outro do seriado "O mundo de Beakman". 
Participaram dessa etapa da pesquisa estudantes do $1 .^{\circ}$ ano do Ensino Médio, sendo 60 alunos da escola pública e 66 da escola particular, num total de 126 alunos. Em cada escola os grupos de alunos foram classificados em função da ordem em que foram apresentados os dois vídeos.

$\mathrm{Na}$ quarta etapa, a fim de verificar a equivalência entre as questões apresentadas nos dois pós-testes, apresentamos o mesmo conjunto de vídeos sobre Aerodinâmica e invertemos a ordem dos dois pós-testes. O segundo pósteste foi apresentado após a exibição do primeiro vídeo, e após o segundo vídeo usamos o primeiro pós-teste, o que possibilitou verificar se havia diferenças nos padrões das respostas dos testes. Participaram dessa etapa estudantes do $1 .^{\circ}$ ano do Ensino Médio da escola pública, totalizando 105 alunos.

\subsection{A primeira etapa: procurando os primeiros indícios}

Utilizando os dois vídeos que discutiam os princípios físicos das máquinas simples, especificamente os sistemas de alavancas, buscávamos trazer indícios de:

i) qual vídeo isoladamente contribuía para o melhor desempenho dos alunos.

ii) quais cenas em cada vídeo se destacavam na opinião dos alunos, a melhor e a pior.

iii) os alunos conseguiam identificar o argumento do vídeo e sabiam expressar o enredo.

iv) qual o perfil midiático dos alunos em relação à TV e em relação aos vídeos educativos de Ciências. 
Em função da nossa hipótese de que os dois vídeos tinham elementos diferenciadores, seja em relação à proposta educativa, seja quanto a elementos específicos da produção audiovisual, foram escolhidos dois grupos de pesquisa para que cada um deles assistisse a um dos vídeos. Uma análise das modificações ocorridas, em relação ao tema alavancas, pela interação com um dos audiovisuais nos forneceria elementos para uma avaliação comparativa dos vídeos.

\subsubsection{População}

Os alunos que participaram da primeira etapa da pesquisa eram 49 estudantes distribuídos em duas salas de aula do 1. $^{\circ}$ ano do Ensino Médio de São Paulo, de escola particular, cursando o período matutino, com idade entre 14 e 17 anos. Do Grupo I participaram 25 alunos e do Grupo II, 24 alunos. Os alunos pertenciam à classe social média, tinham acesso a televisão, videocassete e computador.

\subsubsection{Metodologia}

Cada grupo de pesquisa foi formado com os alunos que compunham uma sala de aula. Os grupos I e II realizaram as atividades propostas num único dia, durante duas aulas seguidas. Os alunos receberam um instrumento de pesquisa com onze questões dissertativas.

As primeiras três questões foram respondidas antes da exibição do vídeo na forma de pré-teste, e foram propostas com o objetivo de fazer um mapeamento dos conhecimentos dos alunos sobre alavancas, antes da 
exposição ao audiovisual, através de uma situação em que se propunha ao aluno levantar uma pedra utilizando-se uma tábua e um cavalete de apoio.

As questões de números quatro a oito, na forma de um pós-teste, foram respondidas após a exibição do vídeo, com intuito de fazer uma avaliação sobre a compreensão dos conceitos envolvidos na utilização de alavancas; as questões nove até onze diagnosticavam o perfil midiático do aluno por meio de perguntas que revelavam a relação do aluno com a televisão.

Os alunos do grupo I assistiram o episódio da série "O Professor", os alunos do grupo II assistiram o episódio da série "O mundo de Beakman".

\subsubsection{Os instrumentos de pesquisa}

Foi elaborado um instrumento de pesquisa composto de 11 questões, o qual por meio de perguntas abertas procurou identificar os conhecimentos prévios dos alunos sobre o tema alavancas e revelar que modificações ocorrem nesses conhecimentos por meio da interação com o audiovisual.

O pré-teste (perguntas 1, 2 e 3) tratou da análise qualitativa de três situações de alavancas, uma inter-resistente, outra interfixa e outra interpotente, apresentadas por meio de figuras constituídas por uma mesma tábua, mesma pedra e mesmo apoio, em posições distintas. No caso interresistente, a pedra fica no meio e nos outros casos a pedra fica no extremo da tábua. Pergunta-se em qual situação é mais fácil manter a pedra levantada, e pede-se que, em cada situação, seja feita relação com objetos/coisas/brinquedos/etc.

Os pós-testes utilizados para os grupos I e II (perguntas 4 a 8) permitiam que as respostas anteriores fossem modificadas ou complementadas pelo 
aluno. Através destas alterações nas respostas, a interpretação que o aluno teve sobre o argumento do vídeo apresentado, e o levantamento de cenas de que o aluno gostou e não gostou, buscou identificar os conhecimentos prévios dos alunos sobre o tema alavancas e as modificações que ocorreram nesses conhecimentos por meio da interação com o audiovisual.

O levantamento do perfil midiático dos alunos foi obtido das respostas às perguntas 9 a 11, as quais trataram de conhecer os seus programas preferidos e a freqüência com que assistiam aos programas de caráter científico.

A seguir, o instrumento utilizado na $1 .^{\mathrm{a}}$ etapa da pesquisa com os grupos I e II.

1) Onde você aplicaria a força para conseguir manter a pedra levantada? Justifique.

a)

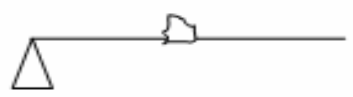

b)

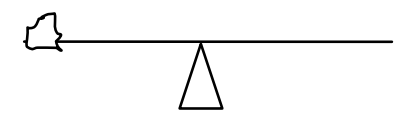

c) pedra

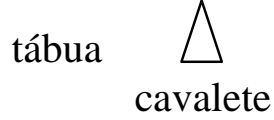

2) Em qual desses casos é mais fácil manter a pedra levantada? Justifique.

3) Relacione em cada um dos casos a, b e c objetos/coisas/sistemas/brinquedos/etc... que você já viu ou usa.

4) Após ver o vídeo se você for alterar alguma das respostas das questões anteriores responda novamente no verso, não mude a resposta na frente.

5) Qual a cena desse vídeo que você mais gostou? Por quê? Descreva a cena. 
6) Qual a cena desse vídeo que você detestou? Por quê? Descreva a cena.

7) Esse vídeo tem uma história? Qual é o enredo dele? Por que estão falando de alavancas?

8) Você entendeu para que serve uma alavanca? Escreva para que ela serve.

9) Você costuma assistir a esse programa em casa? Com qual freqüência?

10) Você conhece outros programas de TV que falem de Ciências? Quais são?

11) De todos os programas da TV brasileira, jornais, entrevistas, ciências, auditório, etc..., qual é o que você mais assiste? Por quê?

\subsubsection{Ampliando a amostra da pesquisa}

Os resultados não esperados desta fase, como a pouca diferenciação entre as respostas apresentadas pelos dois grupos, levaram-nos a uma nova pesquisa, ampliando nossa amostra com um novo grupo III, ao qual foram exibidas as duas séries do vídeo, primeiro "O mundo de Beakman", seguido de "O Professor".

As seguintes questões fizeram parte do estudo do terceiro grupo:

a) qual o tipo de influência trazida pela apresentação consecutiva dos dois vídeos para um mesmo grupo de alunos.

b) de qual dos dois vídeos os alunos gostam mais.

c) qual dos dois vídeos os alunos julgaram ensinar mais física.

O grupo III, formado por 24 alunos e com o mesmo perfil dos grupos I e II, realizou a atividade com a mesma duração (duas aulas), mas em dois dias de uma mesma semana, em cada dia uma aula. $\mathrm{O}$ instrumento de pesquisa foi modificado para estabelecer comparações entre os dois vídeos. 
No primeiro dia, os alunos receberam as mesmas quatro primeiras questões do instrumento utilizado para os grupos I e II, respondendo às três primeiras perguntas antes da exibição do vídeo e à quarta questão após a exibição do episódio de "O mundo de Beakman". No segundo dia receberam um segundo questionário, que foi respondido após a apresentação de um episódio de "O Professor". Esse novo instrumento apresentava questões a fim de estabelecer comparações entre os vídeos. Assim, apenas os alunos do grupo III assistiram aos dois vídeos na seguinte ordem: "O mundo de Beakman" e "O Professor".

O instrumento de pesquisa utilizado na segunda aula, para avaliação dos dois vídeos, é apresentado abaixo.

1) Dos dois vídeos, qual a cena de que você mais gostou? Por quê? Descreva a cena.

2) Qual a cena que você detestou? Por quê? Descreva a cena.

3) Do vídeo do qual você gostou: Esse vídeo tem uma história? Qual é o enredo dele? Por que estão falando de alavancas?

4) Você entendeu para que serve uma alavanca? Escreva para que ela serve.

5) Você costuma assistir a algum desses programas em casa? Qual? Com qual freqüência?

6) Entre os dois seriados "O mundo de Beakman" e "O Professor" qual você prefere ver nas próximas aulas na sala de vídeo? Justifique.

7) Você conhece outros programas de TV que falem sobre Ciência (Física, Química, Astronomia, Biologia)? Quais são?

8) Entre todos os programas de TV que falam sobre Ciência qual você prefere? Por quê?

9) De todos os programas da TV brasileira, jornais, entrevistas, Ciências, auditório, etc..., qual é o que você mais assiste? Por quê?

10) Em qual dos dois vídeos você aprendeu mais Física? 


\subsubsection{Resultados: análise das respostas dos Grupos I, II e III}

\section{Pré-teste}

A primeira pergunta do pré-teste possibilitou identificar que os alunos dos três grupos tinham conhecimento sobre as alavancas, identificando corretamente onde se aplicam forças, de forma que as alavancas apresentadas permaneçam em equilíbrio. Apenas nos grupos II e III foram identificadas situações em que não ocorreria o equilíbrio, sendo a força aplicada no apoio; mesmo assim, no grupo III isso ocorreu apenas em $8 \%$ das respostas e no grupo II apenas em 4\% das respostas.

A tabela 1 resume os dados da segunda pergunta e indica que no préteste os alunos conseguiram comparar as diversas alavancas, mas a maioria dos alunos identificou a alavanca interfixa como aquela à qual eles aplicariam a menor força; como em nenhuma resposta houve menção ao peso da tábua, isso não estava correto. Um número significativo deles conseguiu identificar que, para o problema apresentado, a alavanca inter-resistente era aquela à qual a pessoa aplicaria a menor força para manter o sistema em equilíbrio.

\begin{tabular}{|c|c|c|c|}
\hline Tipo de alavancas: & Grupo I & Grupo II & Grupo III \\
\hline inter-resistente & $22 \%$ & $36 \%$ & $30 \%$ \\
\hline interfixa & $52 \%$ & $60 \%$ & $41 \%$ \\
\hline interpotente & $0 \%$ & $0 \%$ & $3 \%$ \\
\hline Todas são iguais & $26 \%$ & $4 \%$ & $26 \%$ \\
\hline
\end{tabular}

Tabela 1: Alavanca a que se aplica a menor força. 
A terceira pergunta indicava o grau de reconhecimento das alavancas no cotidiano do aluno; a tabela 2 resume os principais elementos apresentados.

\begin{tabular}{|c|c|c|c|}
\hline $\begin{array}{c}\text { Exemplos de alavancas reconhecidas pelos alunos em } \\
\text { seu cotidiano: }\end{array}$ & Grupo I & Grupo II & Grupo III \\
\hline inter-resistente & & & \\
Não sabe & $32 \%$ & $29 \%$ & $87 \%$ \\
Carrinho de mão & $56 \%$ & $8 \%$ & $0 \%$ \\
Pontes, mesas, banco (apoio dos dois lados) & $12 \%$ & $45 \%$ & $12 \%$ \\
\hline interfixa & & & \\
Não sabe & $12 \%$ & $4 \%$ & $16 \%$ \\
Balança e gangorra & $88 \%$ & $96 \%$ & $66 \%$ \\
Alicate e tesoura & $4 \%$ & $0 \%$ & $4 \%$ \\
\hline interpotente & & & \\
Não sabe & $52 \%$ & $42 \%$ & $37 \%$ \\
\hline Trampolim, grua, lápis, marreta, martelo, raquete & $20 \%$ & $45 \%$ & $20 \%$ \\
\hline
\end{tabular}

Tabela 2: Exemplos de alavanca que os alunos reconhecem em seu cotidiano.

Em relação ao pré-teste, em todos os grupos foi identificado o conceito científico de alavanca devidamente empregado nos casos qualitativos apresentados. O grupo II se destacou porque teve o menor índice de alunos que desconhecem exemplos dos três tipos de alavanca: apenas 29\% desconhecem alavancas inter-resistentes, 4\% desconhecem alavancas interfixas e $42 \%$ desconhecem alavancas interpotentes, os menores índices entre os três grupos. Também foi o grupo II que apresentou o maior índice de exemplos de alavancas interfixas (96\%) e interpotentes (45\%). 


\section{Pós-teste}

Em seguida à apresentação do primeiro vídeo, foi respondido o $1 .^{\circ}$ pósteste. No caso do grupo I o vídeo utilizado foi "O Professor"; no caso do grupo II, "O mundo de Beakman". O grupo II apresentou desempenho pouco melhor que o grupo I, mas ambos os grupos se destacaram por apresentar maior clareza em elementos de mesma natureza das que foram mais exploradas no vídeo: a utilização de uma alavanca no grupo II ("Beakman") e a classificação e identificação dos elementos de uma alavanca no grupo I ("O Professor”).

O grupo III teve o melhor desempenho entre os três grupos: ainda que não tenha alcançado maior índice de acertos, teve melhor desenvolvimento e realizou maior número de alterações nas respostas, maiores modificações em suas justificativas e ampliou o número de exemplos, como podemos ver no gráfico 1, que relaciona o número de modificações nas respostas do pré-teste. 


\section{Gráfico 1: Avanços do pós-teste}

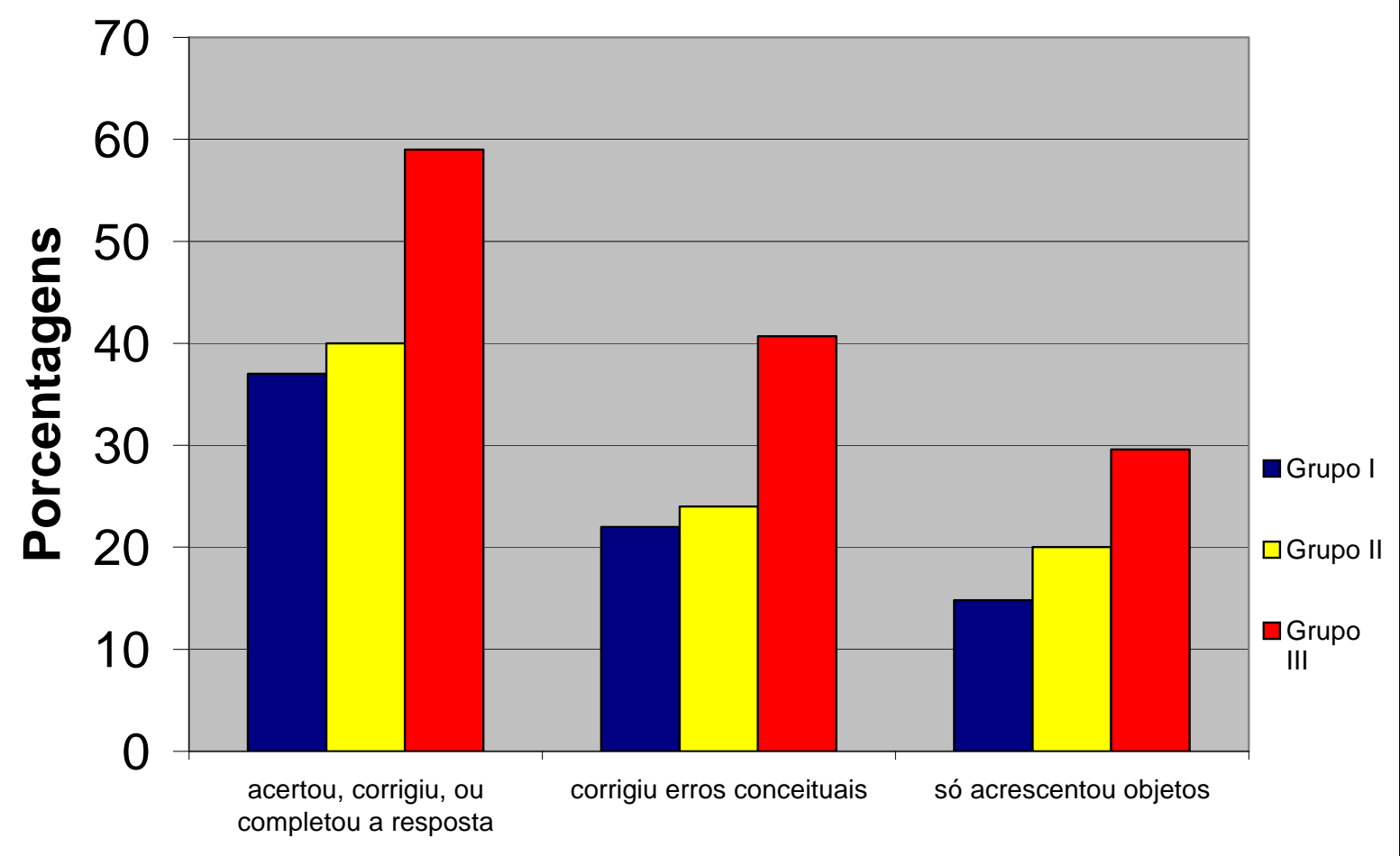

Gráfico 1: Avanços identificados no pós-teste e alterações das respostas do pré-teste.

Em relação às cenas de que os alunos mais gostaram, identificamos que em "O Professor" os alunos gostaram dos exemplos apresentados, como demonstra a resposta do aluno sobre a cena que mais gostou: " $A$ parte do filme que eu mais gostei foi a que ele dá exemplos para as alavancas pois eu tive dificuldade em achar exemplos", e de forma mais específica: "A cena do espremedor de batata, porque são coisas que usamos e não sabíamos. Uma mão espremendo batata". Já em "Beakman" os alunos gostaram mais das explicações, como demonstra a resposta: " $A$ cena que eu mais gostei foi quando a pedra caiu. Beakman mostrou que a pedra era a resistência, a "gangorra" era 0 
ponto de apoio e a nossa força é a potência"; e um número significativo gostou de tudo, como podemos ver no gráfico 2. É interessante notar que no grupo III, se dividido em III-A (alunos do grupo III que gostaram de cenas de "O Professor") e III-B (os que gostaram de cenas de "Beakman"), identificamos os mesmos padrões que nos grupos I e II.

Em relação às cenas das quais os alunos mais gostaram, em ambos os vídeos, são relatadas cenas em que eram apresentadas alavancas que "surpreenderam" os alunos: em "O Professor", o espremedor, os pauzinhos (hashi), a vara de pescar e as locomotivas; em "Beakman", a marreta e o carrinho de mão; neste vídeo os alunos também ressaltaram que gostaram das cenas iniciais que trazem o contexto e a situação-problema "a cena que a pedra cain e mostra as partes da gangorra".

Em relação às cenas das quais os alunos não gostaram, o gráfico 3 mostra que os alunos não gostam principalmente de cenas "forçadas", que eles identificaram principalmente em "O Professor", como mostra a resposta de um aluno: "o que detestei foi a parte da comida, pois eles fazem toda aquela cena patética, tipo "vamos comer de mentirinha" para apenas mostrar um exemplo". Quase não foram encontradas cenas de que os alunos não gostaram em "Beakman", mas uma cena foi identificada como uma cena "forçada": "a cena em que o Lester sacudiu o refrigerante. Porque foi muito fraco. Beakman abriu a garrafa e se molhou todo".

Nos gráficos abaixo o grupo III foi dividido em III-A (alunos do grupo III que só escolheram cenas de "O Professor") e III-B (só escolheram "Beakman"). 


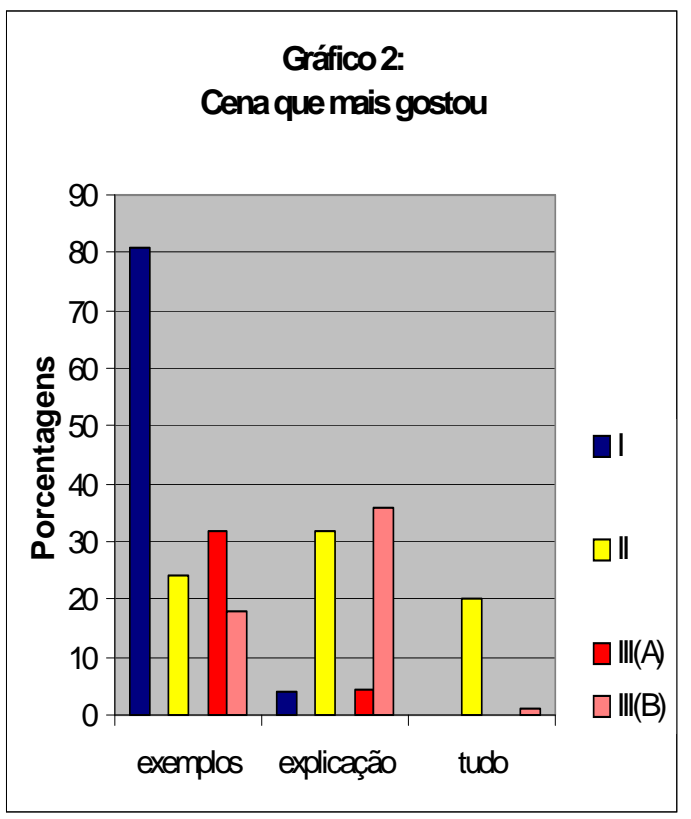

Gráfico 2: Cenas de que mais gostou

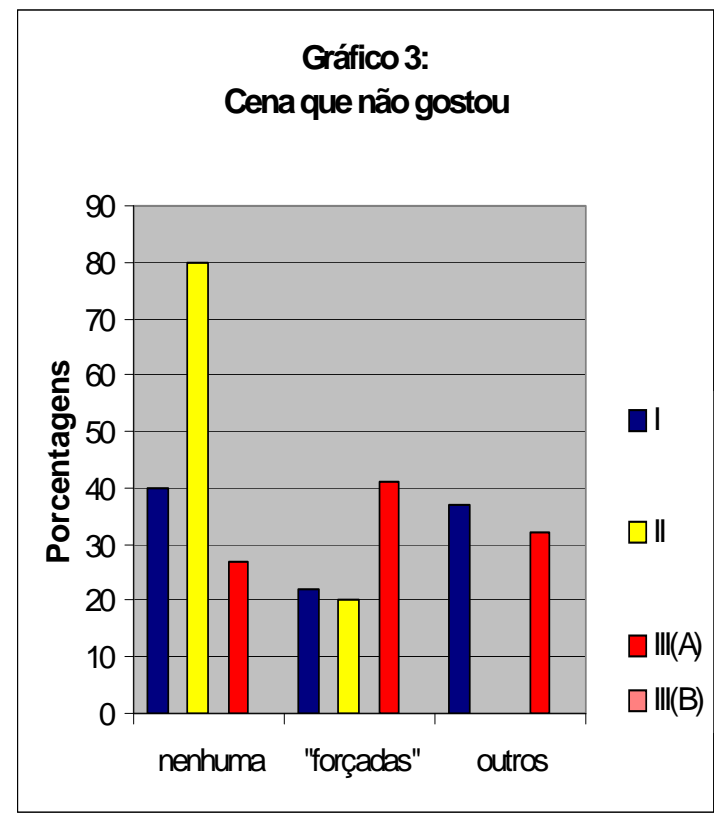

Gráfico 3: Cenas de que não gostou

Em relação ao argumento e ao enredo, os alunos não tiveram dificuldades em identificar como argumento as alavancas. Eles descreveram como enredo de "O Professor" que "Alguém está aprendendo sobre alavancas e vão na casa do professor tirar dúvidas", "uma conversa sobre alavancas pois as usamos em tudo" e "eles vão almoçar usando alavancas e o professor ensina sobre alavancas". Já em "Beakman" eles descreveram como enredo principalmente que "Ele recebeu uma carta sobre alavancas e explicou, há uma pedra que cai e eles têm que retirar"e "A pedra cai e eles têm que retirá-la". No tocante a ambos os seriados, houve alunos que também se referiram ao enredo como sendo o tema do vídeo: as alavancas, em "O Professor" foram cerca de 20\%; já em "Beakman" foram 12\%.

Já com relação ao entendimento de para que serve uma alavanca, a maioria se refere à redução da força que era necessária para realizar algo: "para facilitar a força" ou "para facilitar o trabalho, fazer menor força", ou ainda "aumentar a força”. 
O vídeo "Beakman" foi aquele em que os alunos explicitaram sua fruição e afirmaram que esse é um elemento motivador e desejável, ao mesmo tempo em que os alunos identificaram que "O Professor" foi o que melhor sistematizou o conhecimento, apesar de ser "mais chato".

Sobre qual dos vídeos prefeririam ver nas próximas aulas, os alunos afirmaram: "O mundo de Beakman, pois entretêm mais do que o outro vídeo (que não consegue entreter nada)"; "O mundo de Beakman pois você se diverte $e$ aprende ao mesmo tempo"; "O Beakman é mais divertido e o Professor mais explicativo, dá mais exemplos... O do beakman é mais exemplificado, mais rápido, dinâmico e divertido, tudo maior".

Foi possível identificar que os alunos puderam reconhecer a cooperação entre os dois vídeos: "Acho que ambos me ajudaram a entender, não sei qual foi mais útil, por isso acho que um completa o outro".

A percepção dos alunos de que "O Professor" ensinava mais Física, indicada no gráfico 4, acreditamos estar relacionada com o fato de que a estrutura desse vídeo era mais parecida com as aulas das escolas, como indicou a resposta de um aluno: "Eu acho que os dois programas falam de física, só que o "Professor" fala de um jeito mais técnico, parece uma aula". 


\section{Gráfico 4:}

Vídeo que ensina mais física, na percepção dos alunos que assistiram os dois vídeos (grupollI)

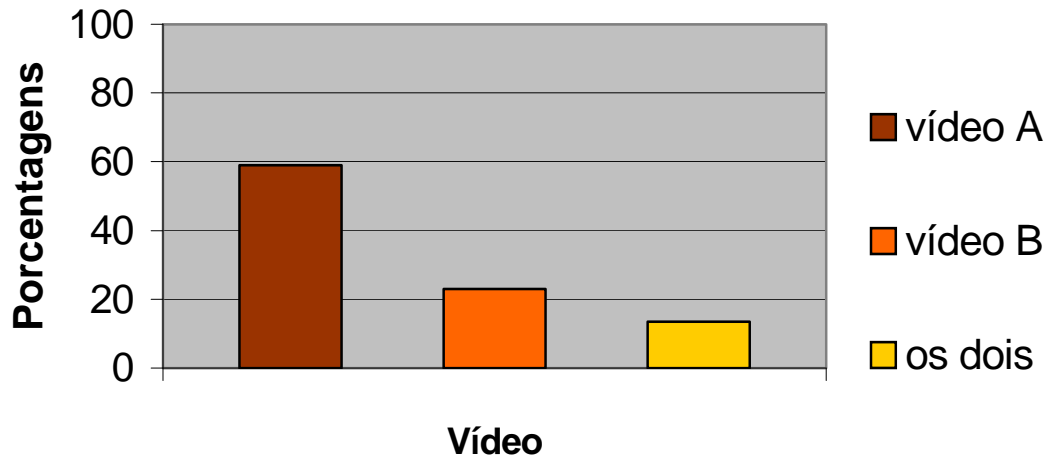

Gráfico 4: Vídeo que na opinião dos alunos ensina mais Física

No entanto, essa percepção mostra-se equivocada, sendo negada pelos resultados apresentados no gráfico 5, obtidos com o grupos I e II, para os quais houve a apresentação de apenas um dos vídeos, "Beakman" (vídeo B) e "O Professor" (vídeo A). Esses resultados são levemente favoráveis a "Beakman" (vídeo B), mas apresentam a mesma ordem de grandeza. Só houve melhora significativa no grupo III (vídeos B, A) com a apresentação dos dois vídeos, indicando que a cooperação entre eles pode ser um fator relevante no emprego dos audiovisuais em sala de aula.

Gráfico 5:

Desempenho geral dos vídeos

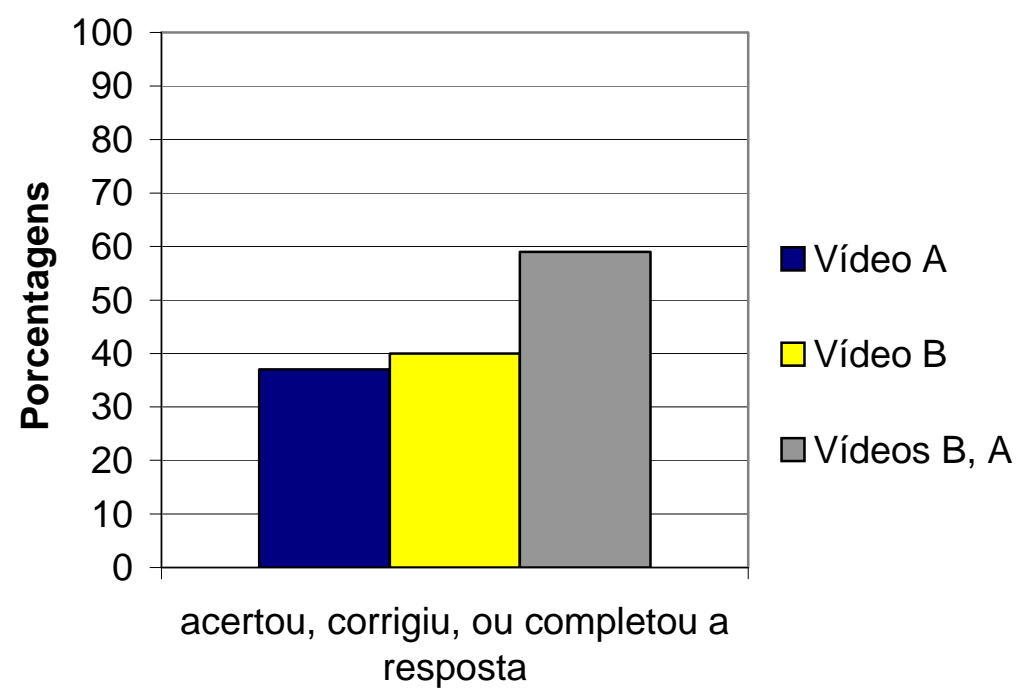

Gráfico 5: Desempenho geral dos vídeos 
O perfil midiático dos alunos foi identificado por meio de duas perguntas do pós-teste: "Você conhece outros programas de TV que falam sobre Ciência (Física, Química, Astronomia, Biologia)? Quais são?" e "De todos os programas da TV brasileira, jornais, entrevistas, ciências, auditório, etc... qual é o que você mais assiste? Por quê?". A tabela 3 apresenta os dados obtidos :

\begin{tabular}{|c|c|c|c|}
\hline & Grupo I & Grupo II & Grupo III \\
\hline Costuma a assistir "Beakman" & $70 \%$ & $81 \%$ & $45 \%$ \\
\hline Costuma assistir "O Professor" & $36 \%$ & $8 \%$ & $5 \%$ \\
\hline Globo Ciência, Discovery, NatGeo & $32 \%$ & $32 \%$ & $25 \%$ \\
\hline Futura, GNT & $15 \%$ & $4 \%$ & $10 \%$ \\
\hline Filmes & $15 \%$ & $16 \%$ & $10 \%$ \\
\hline Séries & $11 \%$ & $12 \%$ & $15 \%$ \\
\hline Programas de auditório & $8 \%$ & $16 \%$ & $25 \%$ \\
\hline Entrevistas & $8 \%$ & $16 \%$ & $15 \%$ \\
\hline Telejornais & $48 \%$ & $40 \%$ & $45 \%$ \\
\hline MTV & $11 \%$ & $20 \%$ & $15 \%$ \\
\hline Dovelas & $8 \%$ & $4 \%$ & $5 \%$ \\
\hline
\end{tabular}

Tabela 3: Perfil midiático dos alunos 
Podemos identificar nos três grupos um perfil que privilegia a busca por informações, principalmente a divulgação científica. Os programas de entretenimento como filmes, telenovelas, seriados etc. também estão presentes de forma expressiva, mas se mostram em segundo plano no interesse dos alunos. O seriado "O mundo de Beakman" é o programa que tem a maior penetração nessa amostragem, reforçando a hipótese de que os audiovisuais lúdicos e que propiciam o entretenimento podem colaborar para o ensino, já que é possível observar que alunos fruem desse audiovisual em suas casas para seu entretenimento e formação científica.

\section{Resultados gerais da $1 .^{a}$ etapa}

Em relação ao conceito físico de alavancas, houve avanços que puderam ser identificados pela ampliação do repertório científico do aluno, o que indicou a atuação na zona de desenvolvimento proximal (Vygotsky, 1984), ainda que isso não tenha significado alteração da resposta inicial; o gráfico 1 apresentou indícios de que individualmente os vídeos apresentam resultados equivalentes, ainda que possa ser observado que o grupo II teve o melhor desempenho em ambos os casos.

Em relação a acrescentar objetos, o gráfico 1 mostrou 20\% de melhoria com "Beakman", enquanto houve somente 15\% de melhoria com "O Professor"; esse fato foi bastante relevante, já que o gráfico 2 mostra que os alunos que assistiram ao vídeo tinham maior interesse pela explicação (32\%), enquanto que os alunos que assistiram a "O Professor" tinham maior interesse pelo conjunto de exemplos utilizados para ilustrar o assunto (81\%). 
Os resultados observados no grupo III acompanharam as estatísticas sobre o principal interesse para os alunos que gostaram mais de "Beakman" (III-B) e para os que gostaram mais de "O Professor" (III-A) respectivamente, como também se observa no gráfico 2.

A composição dos dois vídeos no grupo III apresentou resultados significativamente melhores, ao acrescentar objetos e completar a resposta; além disso teve a menor porcentagem de alunos que não alteraram nenhum conhecimento (30\%).

O seriado "O Professor" foi aquele que provocou maior incômodo aos alunos: $60 \%$ deles não gostaram de alguma cena, somente $40 \%$ não tiveram queixas dele, enquanto que apenas $20 \%$ dos alunos tiveram queixas de "Beakman" (gráfico 3).

Apesar de não ser o vídeo do qual mais gostaram, os alunos classificaram "O Professor" como aquele que ensina mais Física (gráfico 4), já que é mais parecido com a aula. O gráfico 5 mostra que a percepção de que ele ensina mais é falsa, pois quase não há diferença entre os desempenhos obtidos, e "Beakman" apresentou um melhor desempenho geral.

\section{Considerações sobre a $1^{\mathrm{a}}$ etapa}

Os resultados mostraram que o vídeo mais estimulante para os alunos foi "Beakman" e que ele teve um desempenho didático melhor. Entretanto, "O Professor" foi aquele classificado pela maioria dos alunos como o vídeo que ensina mais Física. Essa percepção é falsa e pode estar ligada à semelhança de "O Professor" com a prática da sala de aula, a qual, utilizando uma 
linguagem "didática", acaba por impor uma maior "veracidade" ao vídeo. Individualmente, nenhum deles apresenta desempenho significativamente melhor do que o outro, mas com a combinação deles, como foi realizado com o grupo III, houve uma melhora significativa.

"Beakman" foi o que teve menor rejeição e os alunos se interessaram mais pelas explicações, enquanto que "O Professor" apresentou a maior rejeição. Entre as qualidades explicitadas pelos alunos em "O Professor", foi ressaltado o conjunto de exemplos utilizados para ilustrar o assunto; já em "Beakman" os alunos ressaltam as explicações apresentadas. No entanto, o grupo II ("Beakman"), acrescentou mais objetos no pós-teste que o grupo I (“O Professor"). A contextualização de "Beakman", baseada na necessidade de utilizar alavancas, pode ser apontada como o fator que propiciou o interesse por parte dos alunos nas explicações, o que deve ter levado a um melhor desempenho.

Os melhores resultados foram obtidos com a apresentação dos dois vídeos e isto nos permitiu levantar a hipótese de que eles sejam complementares, um contextualizando e o outro sistematizando. Isso nos levou a indagar se a ordem em que os vídeos são projetados é relevante; assim, essa questão foi incorporada à nossa investigação nas etapas posteriores.

\subsection{A segunda etapa: analisando a ordem das projeções dos}

\section{vídeos}

Nessa etapa da investigação usamos o mesmo conjunto de vídeos sobre o tema alavanca, utilizado na primeira etapa, sendo reformulados os 
instrumentos de pesquisa para avaliar a influência da ordem da apresentação dos vídeos.

A divisão dos participantes, nessa etapa, em dois grupos de pesquisa, buscava trazer indícios de:

i) qual o tipo de influência trazida pela apresentação consecutiva dos dois vídeos para um mesmo grupo de alunos.

ii) qual a ordem de apresentação que trazia melhor desempenho dos alunos.

iii) qual dos dois vídeos os alunos julgaram ensinar mais Física.

iv) qual dos dois vídeos os alunos gostaram mais.

\subsubsection{População}

Os alunos que participaram da segunda etapa da pesquisa são 64 estudantes de duas salas de aula do $1 .^{\circ}$ ano do Ensino Médio, da mesma escola dos grupos I, II e III da primeira etapa.

\subsubsection{Metodologia}

Os alunos de uma mesma sala de aula formavam um grupo de pesquisa. Os grupos A e B realizaram as atividades propostas num único dia, durante duas aulas seguidas. Inicialmente os alunos receberam um instrumento de pesquisa com quatro questões dissertativas, o pré-teste sobre 
alavancas. Após ver o primeiro vídeo, os alunos receberam o primeiro pósteste, com três questões dissertativas. Por fim eles assistiram ao segundo vídeo do conjunto e responderam o segundo pós-teste, com três questões dissertativas.

Os alunos do grupo A primeiro assistiram ao vídeo de "O Mundo de Beakman", e em seguida a "O Professor". Os alunos do grupo B assistiram primeiro a "O Professor", e posteriormente a "O mundo de Beakman".

\subsubsection{Os instrumentos de pesquisa}

Para avaliar a influência da seqüência de apresentação dos vídeos, reformulamos os instrumentos de pesquisa, elaborando, além de um pré-teste, outros dois pós-testes. A reformulação visou a aprofundar a investigação sobre os aspectos conceituais das alavancas e a generalização desses conceitos em situações cotidianas, e principalmente identificar se a seqüência de apresentação dos vídeos promove diferenças no desempenho dos alunos. Retiramos a análise de perfil midiático, que julgamos estar bem delineada na primeira etapa, e também retiramos a avaliação das cenas das quais os alunos mais gostavam e aquelas das quais não gostavam.

As três primeiras perguntas do pré-teste buscavam avaliar em situações do cotidiano do aluno o conhecimento da relação entre a distância, o apoio e a resistência, e entre o apoio e a potência nos três tipos de alavanca, no primeiro caso a interfixa, no segundo a inter-resistente e no terceiro a interpotente. A 
quarta questão buscava levantar as alavancas que o aluno identificava em seu corpo ou em seu cotidiano; ela foi motivada pelas respostas obtidas na primeira etapa da pesquisa, na qual os alunos se mostraram surpresos ao descobrir as alavancas no corpo, e também mencionaram ter dificuldades em encontrar exemplos de alavancas.

Instrumento utilizado como pré-teste

1) Se quisermos cortar uma caixa de papelão bem dura, qual das duas tesouras você usaria? Explique por que não usaria a outra.
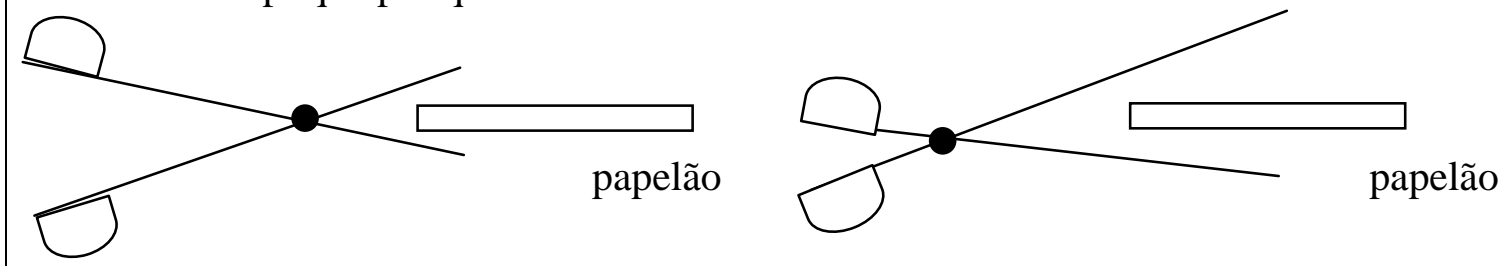

2) Para grampear um trabalho muito grande, com mais de 40 folhas, é preciso um grampeador especial, com um grampo mais forte e um cabo bem maior que os grampeadores normais. Por que o cabo deve ser tão grande?

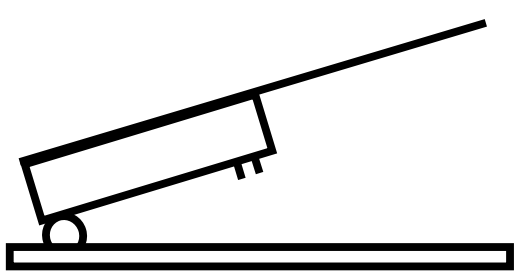

3) Num churrasco uma pessoa está com dificuldade de pegar o gelo no balde de gelo porque está segurando bem no meio do pegador de gelo. Em que lugar ele deve segurar o pegador para fazer mais força e segurar o gelo? Dê uma explicação.

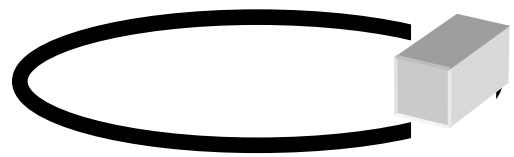

4) Se um colega perguntasse se você tem uma alavanca, o que você responderia? 
O primeiro pós-teste foi elaborado com a finalidade de permitir que se modifiquem as respostas do pré-teste (questão 5); para avaliar o aprendizado dos principais elementos de uma alavanca - ponto de apoio, resistência e potência (questão 6); e a capacidade de extrapolar esses conceitos para solucionar uma situação-problema baseada no cotidiano (questão 7).

Instrumento utilizado como primeiro pós-teste

5) Após assistir ao vídeo, faça as modificações que você achar necessárias em suas respostas das questões 1, 2, 3 e 4 .

1)

2)

3)

4)

6) Nos 3 casos (tesoura, grampeador e pegador de gelo) indique em que lugar estão o apoio, a resistência e a potência

7) Um pai quer brincar com seu filho de 4 anos numa gangorra. Ele coloca o filho na cadeirinha de um lado da gangorra e senta na outra cadeirinha, mas desse jeito ele não consegue brincar pois o filho nunca desce, só fica em cima. Onde o pai deve sentar para brincar com seu filho na gangorra? Dê uma explicação. 
O segundo pós-teste foi elaborado com a finalidade de avaliar a

capacidade de utilizar o conceito de alavanca para explicar o funcionamento de uma tesoura (questão 8); para identificar os elementos das alavancas no corpo (questão 9), e para avaliar a capacidade de explorar as alavancas presentes em situações cotidianas que não foram abordadas nos vídeos (questão 10).

\section{Instrumento utilizado como segundo pós-teste}

8) Se quisermos cortar um pedaço de cartolina com uma tesoura, em que parte da tesoura devemos colocar a cartolina para ficar mais fácil cortá-la, na região 1, 2 ou 3? Explique.

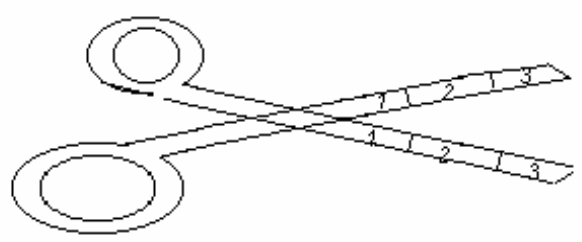

9) O nosso braço é uma alavanca? Nesse sistema, onde estaria o apoio, a resistência e a potência?

10) Você acha que existe alguma alavanca nas figuras abaixo? Explique por que. Onde estaria a resistência, a potência e o apoio? Qual seria a finalidade da alavanca em cada figura?

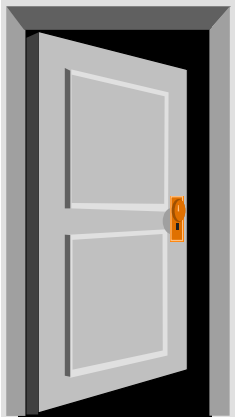

a)

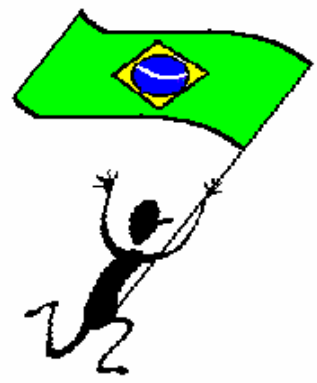

b) 


\subsubsection{Resultados}

O pré-teste avaliou o conhecimento prévio dos alunos sobre alavancas, utilizando a tesoura como uma alavanca interfixa, um grampeador como alavanca inter-resistente e um pegador de gelo como alavanca interpotente. Os alunos foram questionados sobre em qual posição deveriam empregar a força para melhor realizar as tarefas para as quais esses equipamentos foram projetados, respectivamente cortar, grampear e pegar. Os alunos mostraram ter conhecimento sobre alavancas interfixas e inter-resistentes, e apresentaram dificuldades apenas com a alavanca interpotente, o pegador de gelo. A última pergunta do pré-teste questionava se o aluno tinha alguma alavanca. Essa questão foi inserida porque nas etapas anteriores identificamos dificuldade em reconhecê-las. Os resultados mostraram que nessa etapa os alunos identificaram que possuíam alavancas, com destaque para os braços que foram reconhecidos como alavancas. O gráfico 6 apresenta resultados do préteste da segunda etapa, com a porcentagem de respostas em que se identifica a aplicação da força na região em que se faz uma força menor, para realizar a função planejada para cada tipo de alavanca apresentada. A última questão do pré-teste procurou identificar se os alunos reconheciam que tinham alavancas. 


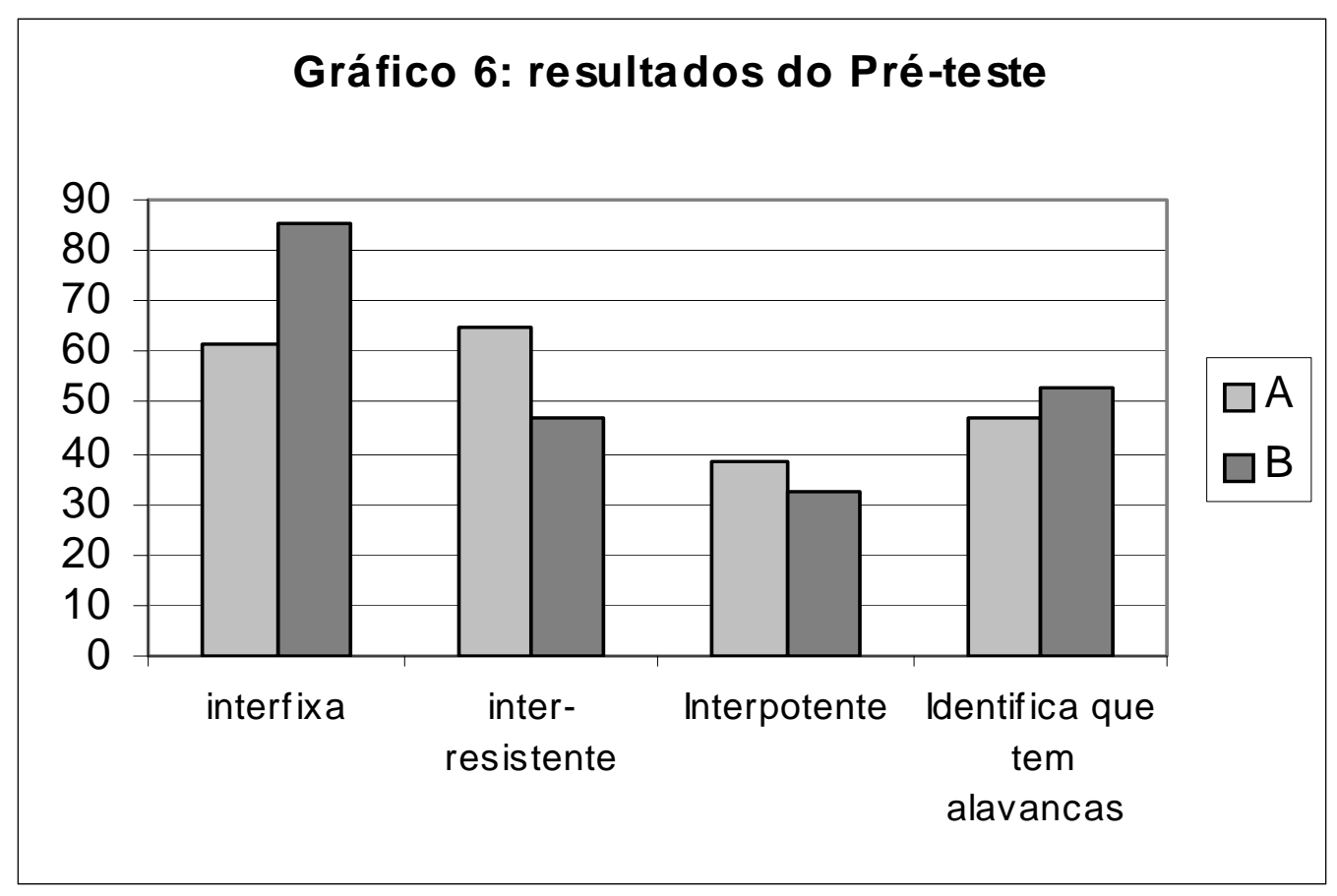

Gráfico 6: Pré-teste sobre alavancas.

O gráfico 6 mostra que os alunos detém conhecimento sobre o funcionamento das alavancas, principalmente a interfixa; mostra também que esses grupos não tiveram dificuldade em reconhecer que têm alavancas, e houve muitas referências às partes do corpo, principalmente o braço.

Após responder ao pré-teste, o grupo A assistiu a "Beakman", e o grupo B assistiu a "O Professor", respondendo, em seguida, ao $1 .^{\circ}$ pós-teste. As questões formuladas buscavam identificar o apoio, resistência e potência nos três tipos de alavancas, e aplicá-los para resolver uma situação-problema ambientada numa cena cotidiana de gangorra.

Os gráficos 7 e 8 , referentes ao $1 .^{\circ}$ pós-teste, mostram as características individuais dos vídeos e apresentam os dados obtidos com o instrumento utilizado como primeiro pós-teste. 
O gráfico 7 apresenta as respostas para uma cena do cotidiano em que um pai e seu filho brincam numa gangorra. Para solucionar essa situaçãoproblema, os alunos deveriam utilizar os conceitos e os elementos de uma alavanca interfixa.

O acerto com justificativa não-científica: havia indicação correta na figura da posição que o pai deveria assumir, mas a explicação não é a científica. "Ele tem que sentar mais perto do apoio para que o filho não precise fazer tanta força".

O acerto com justificativa científica: havia indicação correta na figura da posição que o pai deveria assumir, e a explicação é a científica. "Como não conseguimos deixar o filho mais longe do ponto de apoio, colocamos o pai perto do ponto de apoio".

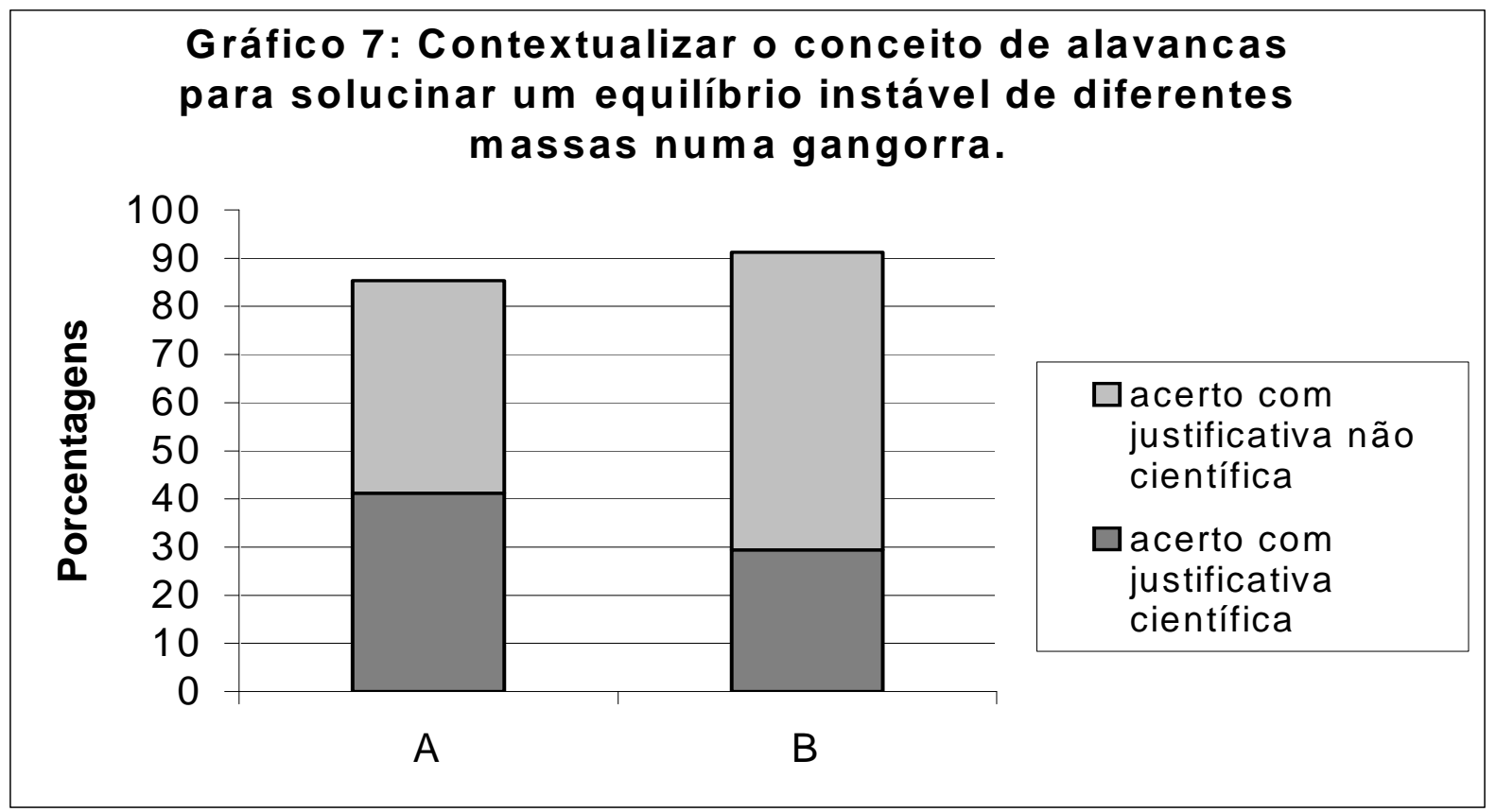

Gráfico 7: Identificar numa gangorra elementos de uma alavanca

O gráfico 7 indica que, apesar de ambos os grupos apontarem corretamente a posição em que o pai deveria sentar-se, houve um 
desempenho melhor do grupo A para solucionar o problema de acordo com o conhecimento científico (40\%).

O gráfico 8 apresenta os resultados sobre a identificação dos pontos de apoio, resistência e potência em alavancas interfixas, inter-resistentes e interpotentes, respectivamente em uma tesoura, um grampeador e um pegador de gelo.

Foram consideradas acertos com justificativa científica as respostas que apresentaram os três tipos de alavancas e identificaram corretamente seus elementos, como em: "Tesoura: alavanca interfixa, o apoio está no centro, a resistência numa das extremidades e a potência na outra; Grampeador: alavanca inter-resistente, o apoio está numa extremidade, a potência na outra e a resistência no centro; Pegador de gelo: alavanca interpotente, o apoio numa das extremidades, a resistência na outra e a potência no centro".

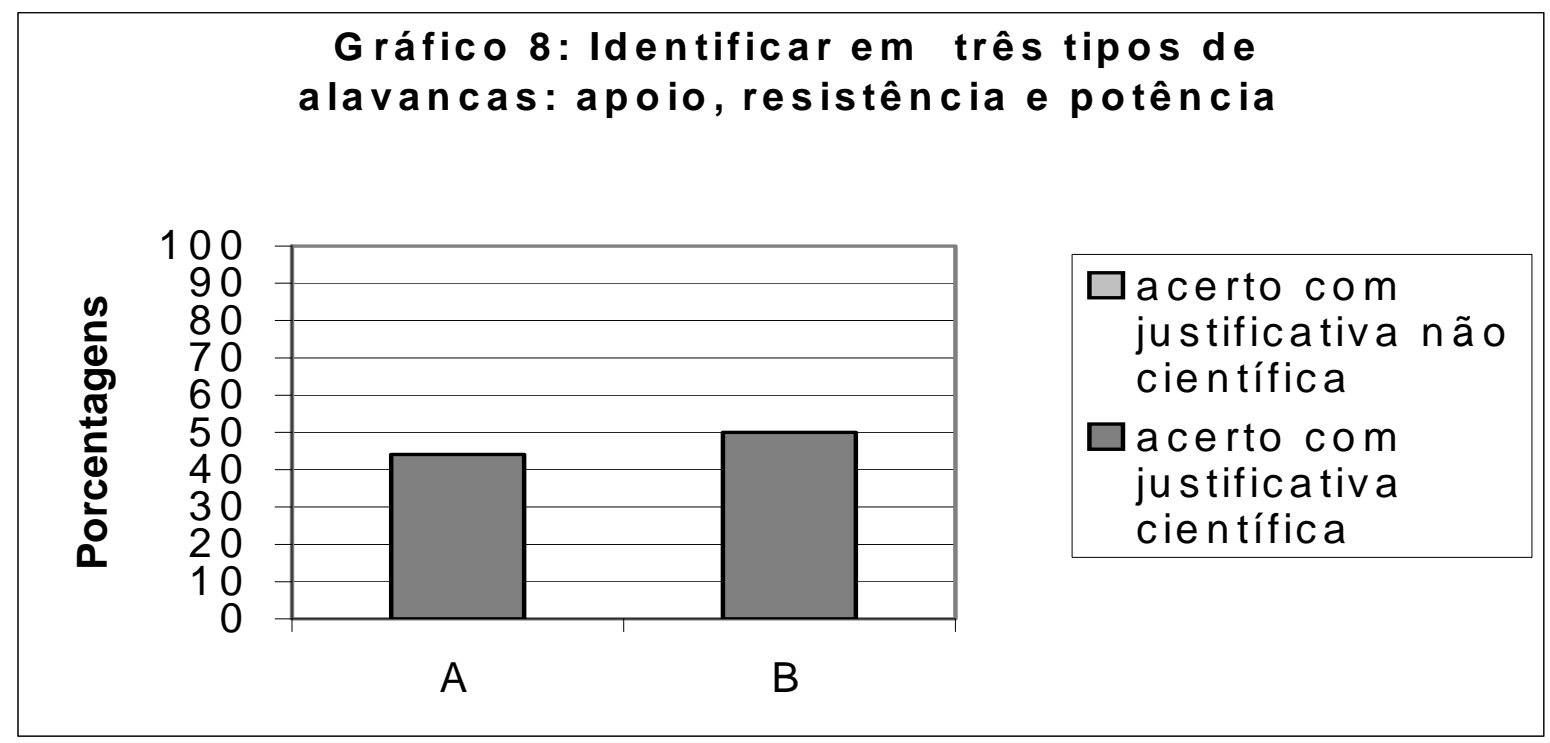

Gráfico 8: Apoio, resistência e potência em alavancas 
O gráfico 8 indica que houve um desempenho melhor do grupo B em exemplificar o conceito de alavancas e identificar seus elementos em objetos do cotidiano.

Após o $1 .^{\circ}$ pós-teste os alunos assistiram ao segundo vídeo. O grupo A assistiu a "O Professor", enquanto o grupo B assistiu a "Beakman"; assim, completaram-se as duas apresentações e o grupo A assistiu aos dois vídeos na ordem "Beakman/O Professor", enquanto o grupo B assistiu aos mesmo vídeos na ordem inversa: "O Professor"|"Beakman". Os gráficos 9, 10 e 11 são referentes ao segundo pós-teste e indicam características da composição de elementos dos dois vídeos. Em todos os casos analisados a composição dos vídeos apresenta desempenho significativamente melhor.

O gráfico 9 apresenta os resultados obtidos para a posição em que se faz uma força menor para cortar um papelão com a tesoura, uma alavanca interfixa. Buscávamos verificar se houve melhora significativa em relação ao primeiro pós-teste, em que se verificou o entendimento sobre o apoio, a resistência e a potência das alavancas.

Foram consideradas acertos com justificativa não-científica as respostas que apresentaram argumentos que não corroboram a escolha pela região 1 (mais próxima do apoio), como por exemplo "Região 1 onde há o atrito dos dois lados da tesoura".

Foram consideradas acertos com justificativa científica as respostas que apresentaram o argumento de que, mais próximo do ponto de apoio, a força exercida pela tesoura seria maior, como em "Região 1, pois a partir do ponto de apoio, quanto mais perto a resistência estiver melhor, pois a força será maior". 


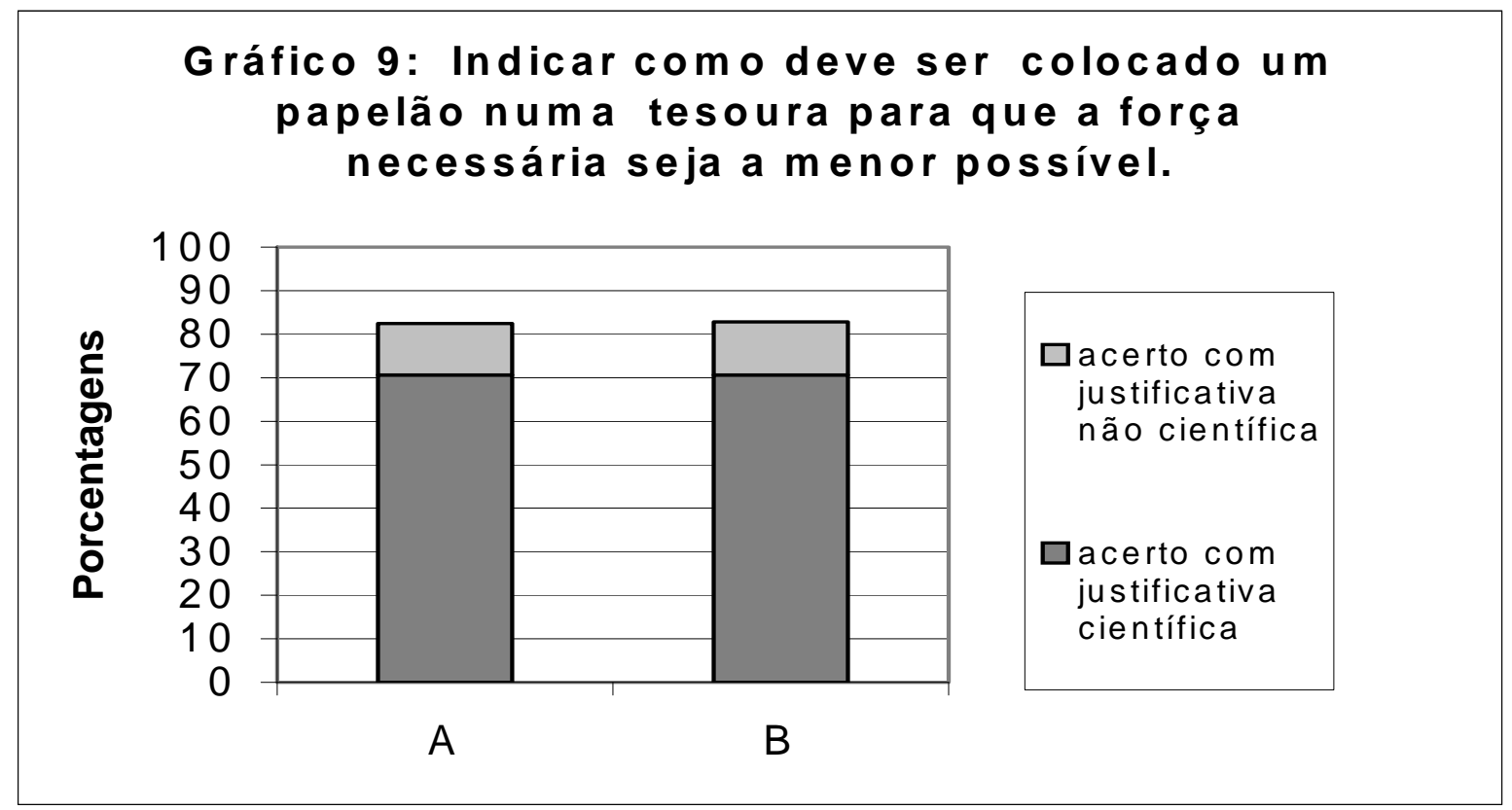

Gráfico 9: Como cortar um papelão com mais facilidade usando uma tesoura.

No gráfico 9 observamos que, em relação à alavanca interfixa, os dois grupos tiveram um entendimento muito semelhante, obtendo um alto índice de acerto em ambos os casos (70\%).

O mesmo se verifica no gráfico 10 , indicando-se um desempenho bastante semelhante entre os grupos A e B (53\% nos dois grupos) e uma melhora em relação à contextualização, em comparação ao gráfico 7.

O gráfico 10 revela a capacidade de se extrapolar o conceito de alavanca em situações que não foram tratadas nos vídeos.

O acerto com justificativa não-científica: indica-se corretamente nas figuras o ponto de apoio, resistência e potência, mas a explicação não é a científica. Em relação á porta: "Te ajuda a empurrar algo pesado com facilidade e sem peso"; com relação à porta-bandeira, "ajuda uma pessoa a segurar algo pesado e comprido". 
O acerto com justificativa científica: indica corretamente nas figuras o ponto de apoio, resistência e potência e a explicação é a científica. Em relação à porta: "Sim, existe alavanca, o negócio que segura a porta na parede é o ponto de apoio. A maçaneta é a potência e a Porta é a resistência. Sua finalidade é fazer menor força para abrir a porta"; com relação à porta-bandeira "Sim, o ponto de apoio é onde ele apoiou o final do pau da bandeira na perna, a potência é no meio onde está a mão dele e a resistência é a bandeira do Brasil. Ela serve para você agitar a bandeira para que ela fique mais rápida".

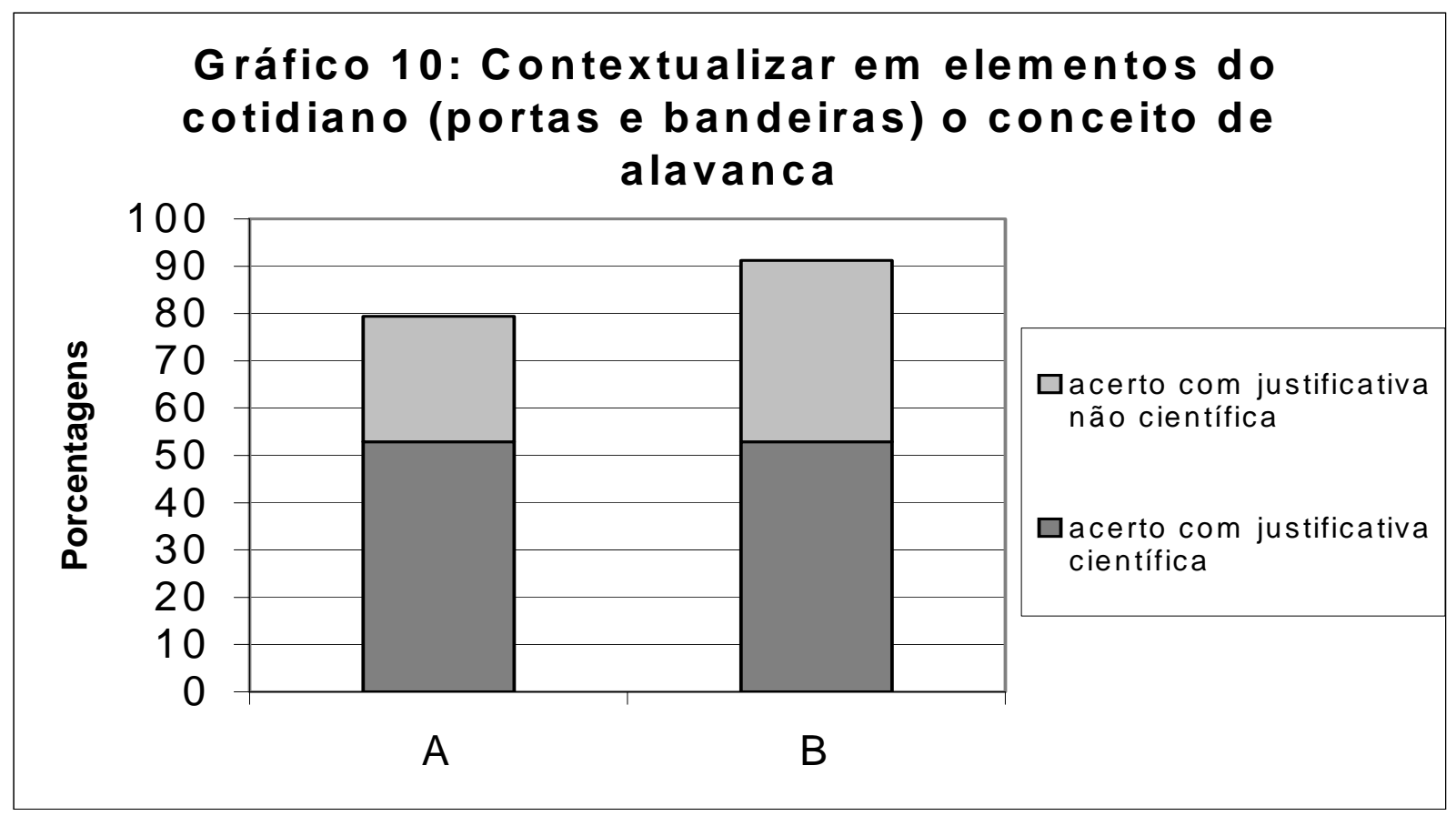

Gráfico 10: As alavancas no cotidiano - portas e bandeiras

Avanços significativos com relação às alavancas interpotentes podem ser identificados se forem comparados o gráfico 10 e o gráfico 6 (pré-teste): a identificação da alavanca passa de $40 \%$ para cerca de $80 \%$, e a explicação científica chega a 50\%. 
O gráfico 11 aponta que, após assistir aos dois vídeos, todos os alunos passaram a identificar seus braços como alavancas presentes no seu corpo, e nesse aspecto houve um maior desenvolvimento do grupo $B$, que assistiu aos vídeos na ordem "O Professor"/"Beakman".

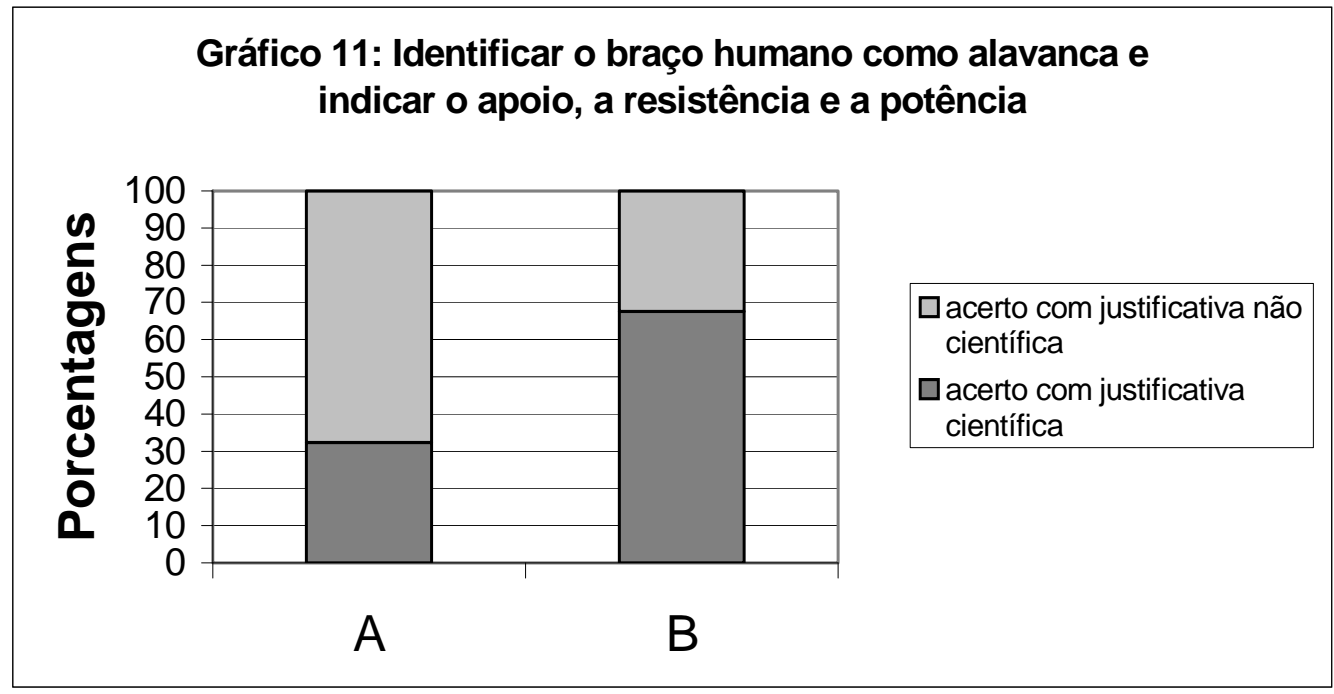

Gráfico 11: As alavancas no corpo humano - o braço

O gráfico 11 indica que ambos os grupos dão um salto em relação à identificação do braço como uma alavanca; o grupo A passa de 35\% no préteste para $100 \%$, e o grupo B de $44 \%$ para $100 \%$. O grupo B apresenta um melhor desempenho na identificação dos elementos da alavanca (apoio, potência e resistência).

Tomando a tesoura, que é uma alavanca interfixa, e que esteve presente em questões nos três instrumentos: para o grupo B a compreensão científica deste tipo de alavanca passou de $41 \%$ (inicial) para $71 \%$ (final). No grupo A essa mudança foi de 56\% (inicial) para 71\% (final).

A extrapolação do conceito de alavanca, para outros objetos e outras situações que não foram abordadas nos vídeos, como uma porta de residência ou a porta-bandeira, também apresentou resultados semelhantes: em ambos 
os grupos foi aplicado corretamente o conceito de alavanca em 53\% das respostas.

Os dois vídeos estudam as alavancas no corpo humano e utilizam o braço como objeto de estudo. "Beakman" mostra o braço como uma alavanca interpotente, e "O Professor" como uma interfixa; após verem os dois vídeos, $100 \%$ dos alunos afirmam que o braço é uma alavanca, mas no grupo A somente 32\% conseguem explicar corretamente, enquanto no grupo B a porcentagem é maior: $68 \%$ explicam corretamente. Isso indica que a sistematização do conhecimento e a escolha da explicação por um tipo mais conhecido de alavanca (gangorra), nessa relação específica com esse conhecimento, teve melhor resultado, ainda que essa sistematização possa não ter sido a mais adequada.

Destacando os resultados apresentados nos gráficos 9, 10 e 11 do segundo pós-teste, vemos que os alunos identificam os elementos das alavancas dentro do contexto do dia-a-dia, e muitos deles conseguem apresentar respostas de conhecimento científico. Comparativamente com o gráfico 7 (1. ${ }^{\circ}$ pós-teste) e com o gráfico 6 (pré-teste), vemos um avanço significativo do conhecimento dos alunos em relação aos três tipos de alavancas.

No gráfico 6, vemos que o entendimento das alavancas interpotentes não chegava a $40 \%$ do grupo, e o entendimento sobre as alavancas interresistentes não chegava a 60\%; após os dois vídeos, no $2 .{ }^{\circ}$ pós-teste, cerca de $80 \%$ conseguem identificar essas alavancas e cerca de $50 \%$ deles conseguem argumentar cientificamente sobre os elementos dessas alavancas. Com 
relação às alavancas interfixas, a comparação entre os gráficos 7 e 9 mostra um significativo avanço no conhecimento científico utilizado na argumentação que buscou se apropriar dos elementos presentes em alavancas interfixas, com expressiva melhora: no $1 .^{\circ}$ pós-teste chegou a $40 \%$ e no $2 .^{\circ}$ pós-teste, a $70 \%$.

Os resultados obtidos na segunda etapa da pesquisa apontam uma expressiva melhora na construção do conhecimento científico, corroborando a hipótese de cooperação entre os vídeos, expressa na $1 .^{a}$ etapa da pesquisa. Não foram encontrados indícios de que a ordem das apresentações influenciem os resultados.

\subsection{A terceira etapa: mudando a natureza dos vídeos e variando as amostras}

Nas etapas anteriores da pesquisa, identificamos em temas tipicamente escolares como alavancas a cooperação entre diferentes naturezas de vídeos, que adotam soluções distintas em relação à linguagem audiovisual e em relação à abordagem educativa: um contextualiza, o outro sistematiza. Resultados obtidos nessas etapas possibilitaram determinar que a ordem de apresentação não teve papel relevante em relação à aprendizagem.

Surgiram então duas questões que procuramos investigar. Em primeiro lugar, questionamos se seriam obtidos resultados semelhantes se tomássemos conteúdos que não são usualmente discutidos na escola, como o princípio de vôo do avião, os quais pudessem evidenciar que os resultados obtidos eram determinados pela cooperação entre os diferentes vídeos. Em segundo lugar, nossa questão consistiu em avaliar a influência das diferentes soluções 
adotadas em relação à linguagem audiovisual. Passamos a investigar se o emprego de vídeos mais semelhantes, que não apresentassem situaçõesproblemas e com contextos mais similares, mas com elementos de linguagem diferenciados, contribuiriam de forma cooperativa.

Nessa etapa, buscamos avaliar o papel desempenhado pelos diferentes elementos da linguagem audiovisual na cooperação que identificamos entre os vídeos de naturezas distintas. Também buscamos averiguar se os alunos da rede pública de ensino obteriam resultados equivalentes aos dos alunos das escolas da rede privada, já que, em relação ao avião, eles deveriam ter experiências muito diferenciadas.

\subsubsection{População}

Os alunos que participaram da terceira etapa da pesquisa são estudantes do $1 .^{\circ}$ ano do Ensino Médio, sendo 60 alunos de escola pública e 66 de escola particular, num total de 126 alunos. Os alunos pertencem, todos, à classe social média; os da escola particular, pertencem, em sua maioria, à classe média-alta, enquanto os da escola pública são, em sua maioria, da classe média-baixa - mas todos eles têm acesso a televisão, videocassete e computador.

\subsubsection{Metodologia}

Os alunos de uma mesma sala de aula formavam um grupo de pesquisa. Os grupos I e II realizaram as atividades propostas num único dia, durante duas aulas seguidas. Inicialmente, os alunos receberam um instrumento de pesquisa com quatro questões dissertativas, um pré-teste sobre os princípios 
de vôo e um levantamento sobre exemplos deles presentes no cotidiano. Após ver o primeiro vídeo, os alunos receberam o primeiro pós-teste, com três questões dissertativas. Por fim, eles assistiram ao segundo vídeo do conjunto e responderam o segundo pós-teste com três questões dissertativas.

Em cada escola os grupos de alunos de uma sala de aula foram nomeados em função da ordem em que foram apresentados os dois vídeos: os grupos nomeados com números pares assistiram primeiramente a "Beakman" e em seguida a "O Professor"; os grupos ímpares assistiram aos vídeos na ordem inversa, primeiro "O Professor" e depois "Beakman".

\subsubsection{Os instrumentos de pesquisa}

O pré-teste tem o intuito de verificar a noção dos alunos sobre os objetos que podem voar e como eles permanecem no ar. Inicialmente, verificamos que tipos de conceitos são associados ao avião, quais são os outros objetos que voam e como se explica o fato de o avião não cair. Verificamos ainda se os alunos conhecem coisas que voam sem motor e, depois, se conhecem coisas que voam sem asas.

Instrumento utilizado como pré-teste

1. Quando se fala em aviões o que vem à sua cabeça?

2. Que coisas você conhece que também voam, além dos aviões?

3. Quando um avião está voando, como ele consegue ficar no alto sem cair? Explique quais as partes do avião que o fazem voar.

4. É possível existir algo que consegue voar sem motor? Dê exemplos.

5. É possível existir algo que consegue voar sem asas? Dê exemplos. 
O primeiro pós-teste tem o intuito de verificar qual o grau de entendimento sobre o princípio de vôo do avião, se o aluno identifica semelhanças e diferenças entre esse princípio de vôo e o de outros objetos que também voam. Também verificamos se o aluno consegue extrapolar o princípio estudado para objetos que originalmente não foram construídos para voar.

\section{Instrumento utilizado como primeiro pós-teste}

6. Das coisas abaixo quais voam pelo mesmo princípio do avião? Tipos:
a) avião de papel
b) Papagaio (pipa)
c) Asa-delta
d) Balão
e) Helicóptero
f) Dirigível
g) Pára-quedas

7. Em todos os exemplos acima, explique em cada caso quais as partes dele que são importantes para ele voar? (se precisar use a parte de trás da folha).

8. Se um carro correr muito rápido ele consegue voar? Explique.

9. Construa um avião de papel. O que você poderia fazer para ele voar melhor?

$\mathrm{Na}$ elaboração do segundo pós-teste, procuramos trabalhar com elementos que permitissem uma análise comparativa entre os dois pós-testes. Em relação ao vôo do avião, especificamos as questões, discriminando a função das asas, do motor e da cabine. Fizemos uma abordagem semelhante para o vôo do helicóptero, discriminando a função do motor, do rotor, da hélice 
na cauda e da cabine. Verificamos se o aluno consegue extrapolar o princípio estudado para objetos que originalmente não foram construídos para voar. Verificamos quais diferenças o aluno identifica entre o vôo do avião, do helicóptero e do dirigível se ocorrer uma parada no motor deles.

\section{Instrumento utilizado como segundo pós-teste}

10. Quando um avião está voando para que serve cada parte dele: asa, motor, cabine.

11. Quando um helicóptero está voando para que serve cada parte dele: cabine, motor, hélice em cima do helicóptero, hélice na parte de trás do helicóptero.

12. Avião a jato e avião a hélice voam pelo mesmo princípio? Quais as diferenças?

13. Quando há uma ventania algumas casas são destelhadas, os telhados saem voando pelo mesmo princípio do avião? Explique.

14. Se um avião, um dirigível e um helicóptero estiverem voando juntos e ao mesmo tempo os motores parassem desenhe a trajetória de cada um até parar.

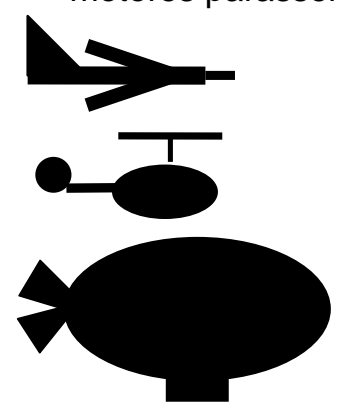

Os três instrumentos de pesquisa apresentados foram utilizados tanto na 3. ${ }^{\mathrm{a}}$ etapa como na $4 .^{\mathrm{a}}$ etapa. 


\subsection{A quarta etapa: invertendo a aplicação dos pós-testes}

Após identificarmos em etapas anteriores a cooperação entre os vídeos, entendemos que poderíamos reforçar os resultados obtidos se fundamentássemos a equivalência entre os pós-testes com evidências experimentais. A fim de investigar a equivalência entre os testes, alteramos a ordem em que eles foram aplicados: o segundo pós-teste passou a ser utilizado após o primeiro vídeo, e o primeiro pós-teste foi utilizado após os alunos terem assistido aos dois vídeos.

Com essa inversão, também pudemos identificar mais claramente os elementos que se destacam em cada vídeo, já que foi possível comparar diferenças entre as respostas dadas pelos grupos que haviam visto apenas um vídeo e os grupos que responderam após ver aos dois vídeos.

A 3. ${ }^{a}$ etapa e a $4 .^{a}$ são equivalentes, metodologicamente; houve apenas a inversão da ordem em que os pós-testes foram utilizados.

\subsubsection{População}

Os alunos que participaram da quarta etapa da pesquisa são estudantes do $1 .^{\circ}$ ano do Ensino Médio da escola pública, totalizando 105 alunos. Os alunos pertencem à classe social média, têm acesso a televisão, videocassete e computador.

\subsubsection{Metodologia}

Os alunos de uma mesma sala de aula formavam um grupo de pesquisa. Os grupos I e II realizaram as atividades propostas num único dia, durante duas aulas seguidas. Inicialmente, os alunos receberam um 
instrumento de pesquisa com quatro questões dissertativas, um pré-teste sobre princípios de vôo. Após ver o primeiro vídeo, os alunos receberam um pósteste (o segundo pós-teste utilizado na etapa 3), com três questões dissertativas. Por fim, eles assistiram ao segundo vídeo do conjunto e responderam a outro pós-teste (o primeiro pós-teste utilizado na etapa 3) com três questões dissertativas. Foram utilizados os mesmos instrumentos de pesquisa apresentados na terceira etapa, apenas foi invertida a ordem de utilização dos pós-testes.

\subsubsection{Os instrumentos de pesquisa}

Os instrumentos já foram apresentados na terceira etapa; foram utilizados os mesmos instrumentos de pesquisa, sendo apenas invertida a ordem de utilização dos pós-testes. Após ver o primeiro vídeo, os alunos receberam o segundo pós-teste da terceira etapa. E após assistir ao segundo vídeo do conjunto, responderam ao primeiro pós-teste da terceira etapa.

\subsection{Resultados da 3. ${ }^{a}$ e da $4 .^{a}$ Etapas}

As etapas 3 e 4 são metodologicamente iguais, a diferença entre elas é a ordem em que os pós-testes foram aplicados. Na $3 .^{a}$ etapa eles foram utilizados na ordem em que foram elaborados; na 4. a etapa os pós-testes foram invertidos em relação à proposta original, a fim de avaliarmos a equivalência das questões e ampliar o potencial de avaliação da contribuição de cada vídeo. Inicialmente, apresentaremos os dados referentes ao pré-teste; faremos uma análise comparativa de todos os oito grupos de pesquisa, que 
participaram das etapas $3 .^{a}$ e $4 .^{a}$, já que em relação ao pré-teste essas etapas são idênticas.

Em seguida, vamos apresentar, para cada questão formulada em póstestes, dois gráficos que apresentam respectivamente os dados das duas etapas (etapa 3. ${ }^{\mathrm{a}}$ e etapa $4 .^{\mathrm{a}}$ ). Para efeito de comparação entre os resultados das duas etapas, identificamos os gráficos com a mesma numeração, mas com sufixo "a" para respostas de alunos que assistiram apenas a um dos vídeos, e com o sufixo "b" as respostas dos alunos que responderam às questões após terem assistido aos dois vídeos.

Em cada gráfico os grupos estarão representados segundo a seguinte ordenação: aqueles que viram primeiramente "Beakman" e depois "O Professor" correspondem aos grupos de números ímpares. Aqueles grupos que primeiramente assistiram a "O Professor" e depois a "Beakman" correspondem aos de números pares. Essa ordem pode ser indiferente no pré-teste, mas, para efeito de comparação dos pós-testes, ela é importante, sendo ainda mais relevante para a comparação entre as etapas 3 e 4, para efetuar a comparação dos avanços obtidos pelos grupos de pesquisa.

\section{Pré-teste}

- A primeira questão formulada no pré-teste busca associações que o aluno faz com o avião, fazendo um levantamento de coisas, objetos, conceitos que permeiam o mundo vivencial dos alunos.

O gráfico 12 apresenta a natureza dos elementos que os alunos associam ao avião, sendo: 
A - Formal: Gravidade. Essa categoria contempla respostas que confrontam a atração gravitacional e a capacidade de voar: "Me vem a cabeça grandes máquinas que desafiam a gravidade".

B - Funcional: Aeroporto, pessoas, asas, pilotos, voar, ter um motor. Essa categoria contempla respostas que enfocam equipamentos e estruturas e pessoal, necessários ao vôo: "Um grande compartimento com motor, asas e que leva pessoas de um lugar para outro".

C - Conceitual: Liberdade, evolução do homem, modernidade. Essa categoria contempla respostas que enfocam conceitos abstratos, como a evolução da humanidade, a evolução tecnológica: "Vem o céu e a evolução dos homens quanto as máquinas".

D - Utilidade (diversão, transporte): Viagem, levar onde quer em menos tempo, meio de transporte. Essa categoria contempla respostas que enfocam a utilidade dos aviões em nossa sociedade: "Um meio de transporte rápido, confortável mais do que os outros transportes".

E - Emoções: medo de voar, de cair, adrenalina. "Um frio na barriga, medo, altura, eu morro de medo, apesar que eu nunca viajei de avião e nem quero". F - Não respondeu.

G - Custo: Preço da passagem: "O alto preço da passagem". 


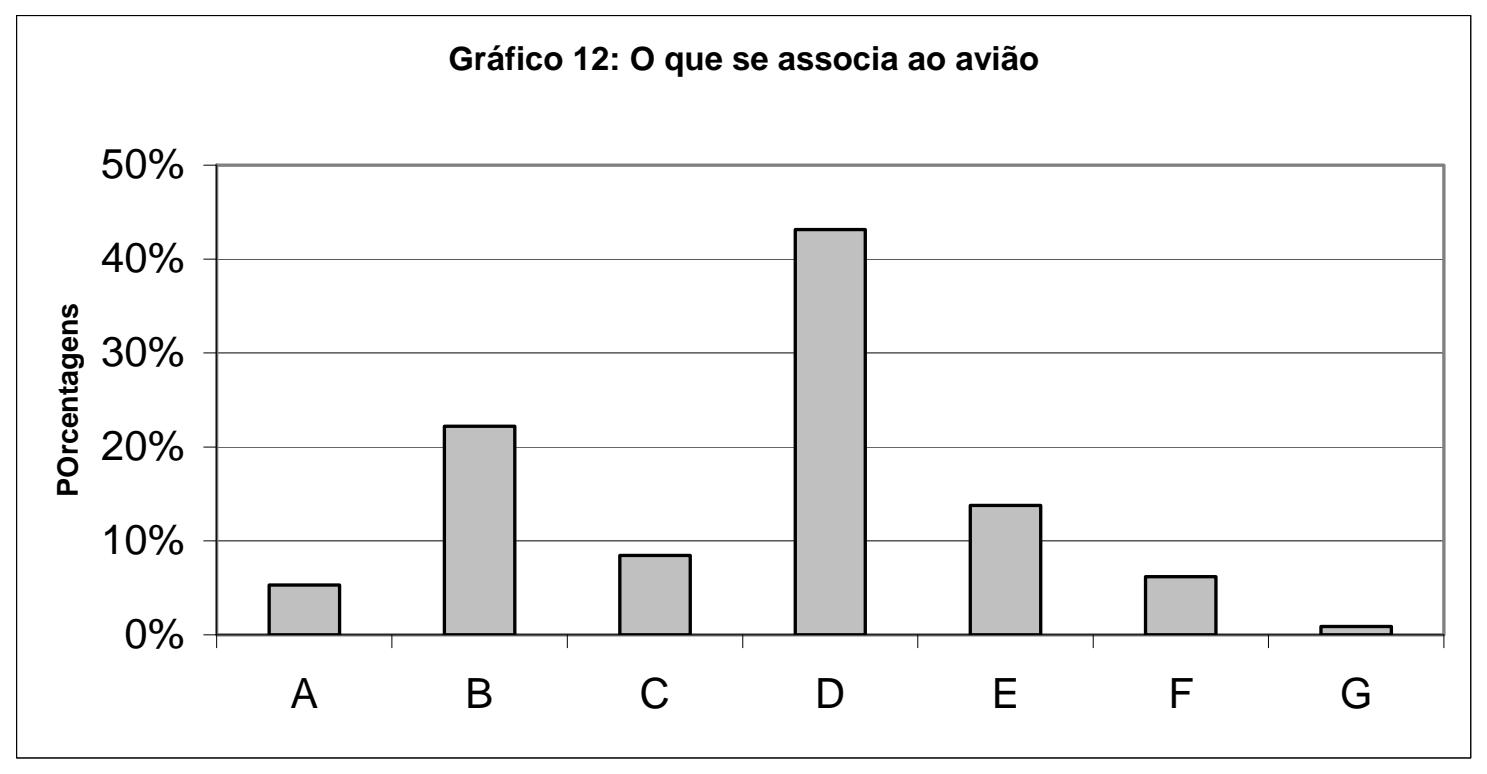

Gráfico 12: O avião e o mundo vivencial do aluno - distribuição por categoria

A principal associação presente é a utilidade do avião, como meio de transporte para viagens, seguida de aspectos funcionais. Os aspectos emocionais, como o medo de cair e a adrenalina de voar, estão presentes principalmente no ensino público, como veremos a seguir.

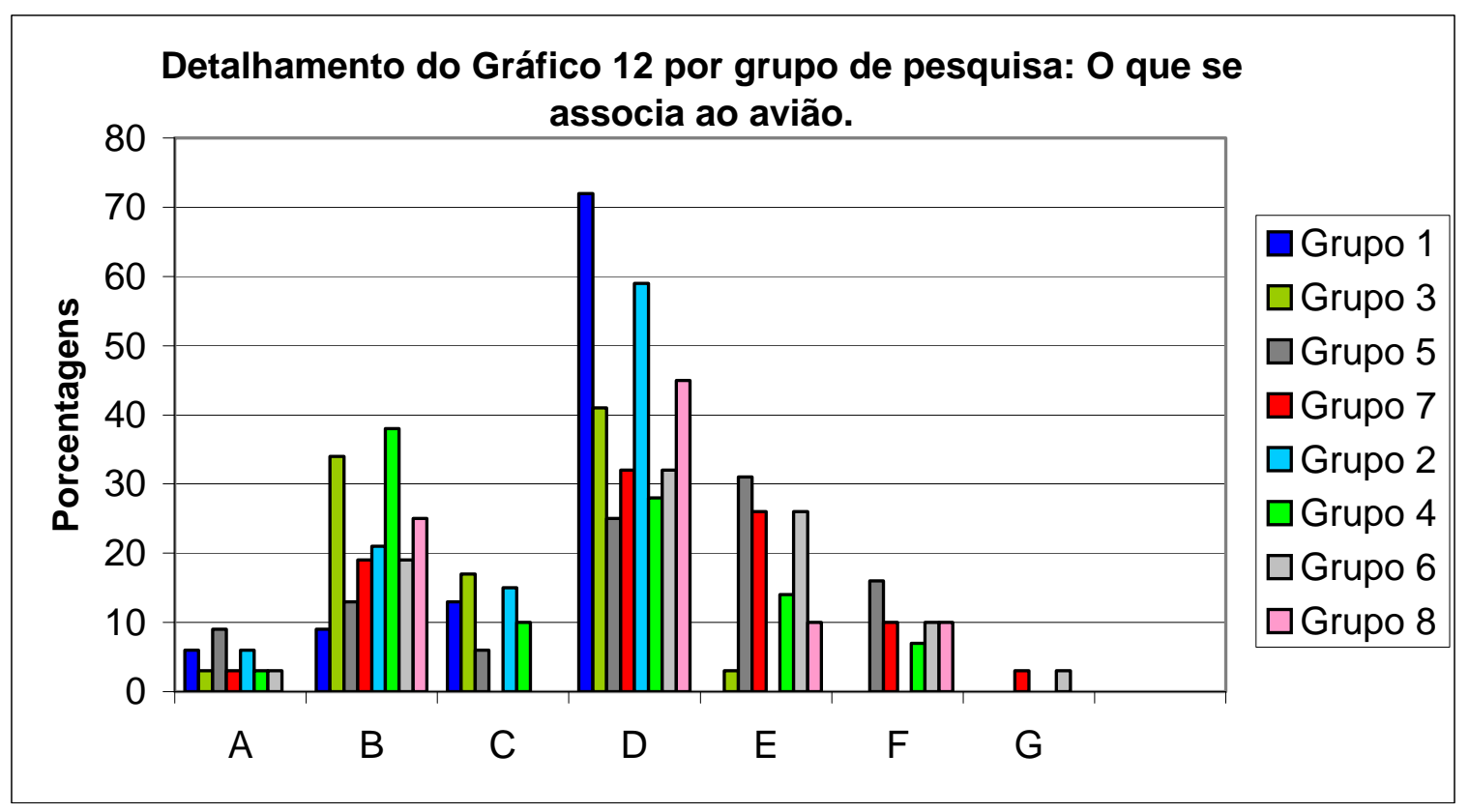

Detalhamento do gráfico 12 por grupo de pesquisa: $O$ avião e o mundo vivencial do aluno distribuição por categoria. 
Aqui fica evidente que, na escola pública (grupos 3 a 8), o medo de voar (E) é uma preocupação presente, enquanto na escola particular (grupos 1 e 2) ele é quase é inexistente. A questão conceitual (C), ligada a aspectos mais gerais como liberdade, evolução, está presente tanto na escola privada como na pública.

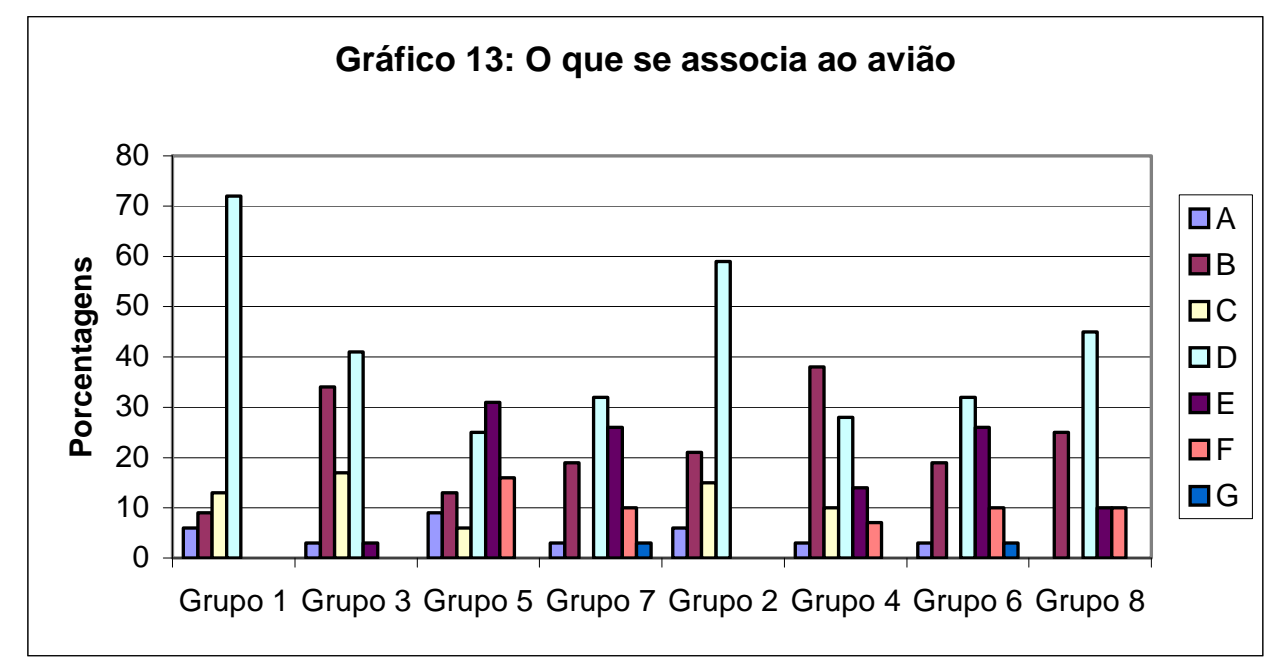

Gráfico 13: O avião e o mundo vivencial do aluno - distribuição por grupo

Nessa distribuição, podemos ver que, em relação aos elementos que os alunos associam ao avião, os alunos das escolas públicas (grupos 3 a 8) e os alunos das escolas privadas (grupos 1 e 2) não são equivalentes. Os grupos 1 e 2 das escolas privadas apresentam um padrão semelhante. Também podemos ver outro padrão de correspondência entre os grupos da escola pública (grupos 3 a 8). Os alunos da escola pública apresentaram o medo de voar associado ao avião e uma preocupação com a questão financeira (preço da passagem), o que não foi relevante na escola privada. Há uma forte presença, na escola pública, dos aspectos funcionais (B), e em ambas o assunto mais relacionado ao avião é sua utilidade (D), principalmente em relação às viagens. 
- Na segunda questão tentamos diagnosticar outras coisas que o aluno conheça que também voam, além dos aviões.

O gráfico 14 apresenta a natureza dos elementos que os alunos associam ao avião, sendo que a classificação foi elaborada observando-se o conjunto de princípios de vôo de cada elemento presentes à resposta, sendo acrescentado ainda um grupo para animais que voam e outro para conceitos como imaginação, pensamento etc.

Os princípios em que baseio a criação das categorias de análise são:

Para o vôo por propulsão, o princípio de ação e reação, como nos foguetes e balões de borracha (bexigas) com ar. Para o vôo dos aeroplanos, o princípio de funcionamento da asa, como o avião, helicóptero, asa-delta. Para o vôo dos balões de ar quente, hidrogênio ou hélio, incluindo os dirigíveis, o princípio da flutuação por diferença de densidade. Para o pára-quedas e para a pipa, a resistência do ar, mas cabe aqui uma ressalva: os pára-quedas mais modernos são navegáveis e também respeitam o princípio de funcionamento das asas; também há na literatura modelos explicativos para a pipa os quais se baseiam no princípio de funcionamento das asas.

As categorias de análise foram elaboradas a partir dos princípios e grupos presentes às respostas:

A - Animais, foguete ou bexiga, balão ou dirigível, helicóptero ou asa-delta, pára-quedas.

B - Animais, balão ou dirigível, helicóptero ou asa-delta.

C - Animais, foguete ou bexiga, helicóptero ou asa-delta.

D - Animais, helicóptero ou asa-delta.

E - Animais. 
F - Animais e imaginação ou pensamento.

G - Foguete ou bexiga, balão ou dirigível, helicóptero ou asa-delta.

H - Animais e balão ou dirigível.

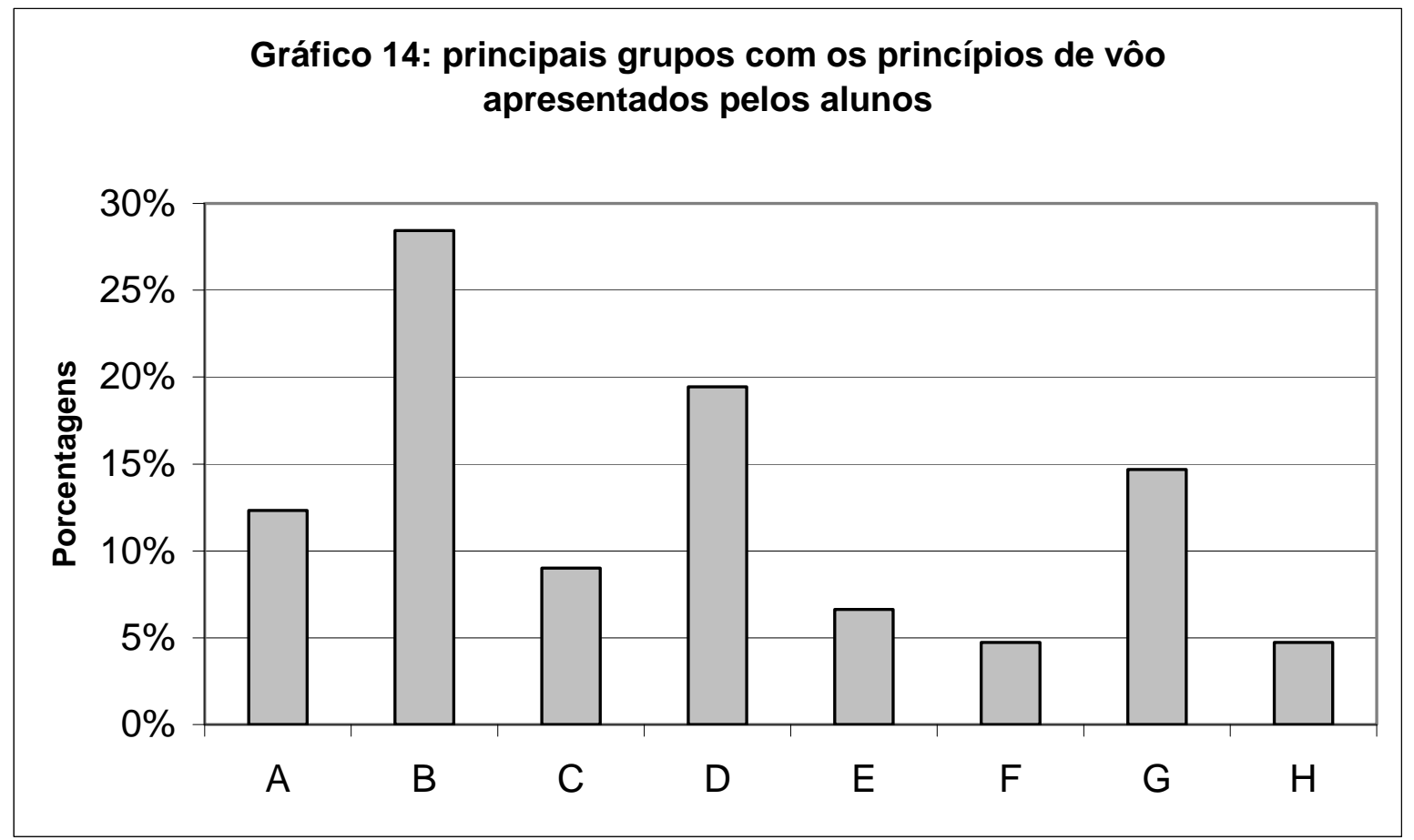

Gráfico 14: Coisas que voam, além do avião - distribuição por categoria.

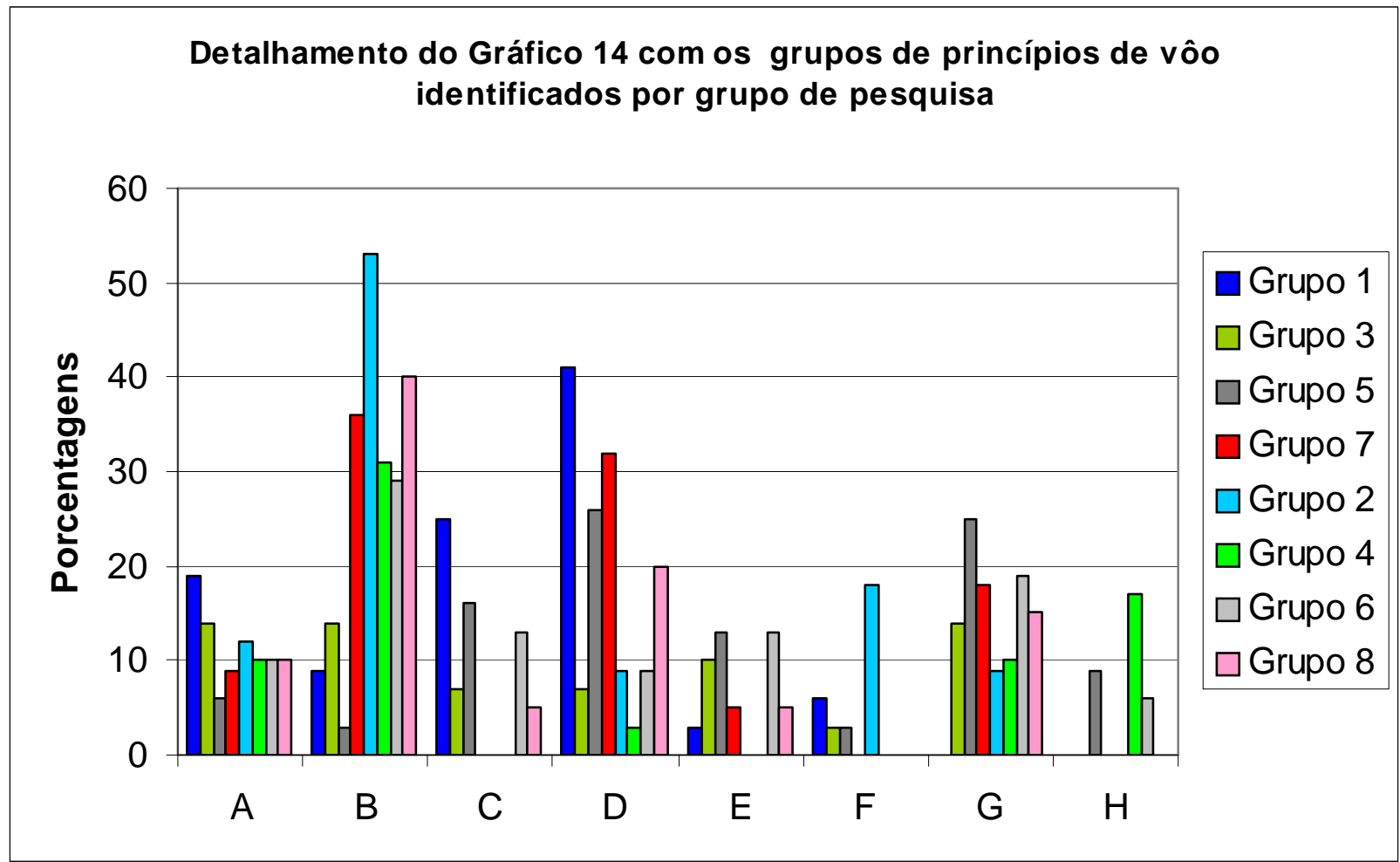

Detalhamento do gráfico 14 por grupo de pesquisa: Coisas que voam, além do avião - distribuição por categoria. 
A categoria que inclui todos os princípios de vôo (A) apresenta uma distribuição bastante homogênea em todos os grupos, aproximadamente 10\% das respostas, tendo em média na escola particular um índice levemente melhor que na pública. A categoria B (ausência apenas do princípio de vôo do foguete) é a que apresenta maior número de respostas; é possível que esse resultado seja devido os balões de ar ou de gás estarem mais presentes no mundo vivencial dos alunos. Isso é reforçado pelo baixo índice da categoria na qual o aluno não menciona o balão (C). Outra categoria bastante importante é a que indica a presença de animais e aeroplanos somente (D); a ausência de animais (G) é mais acentuada na escola pública (grupos 3 a 8).

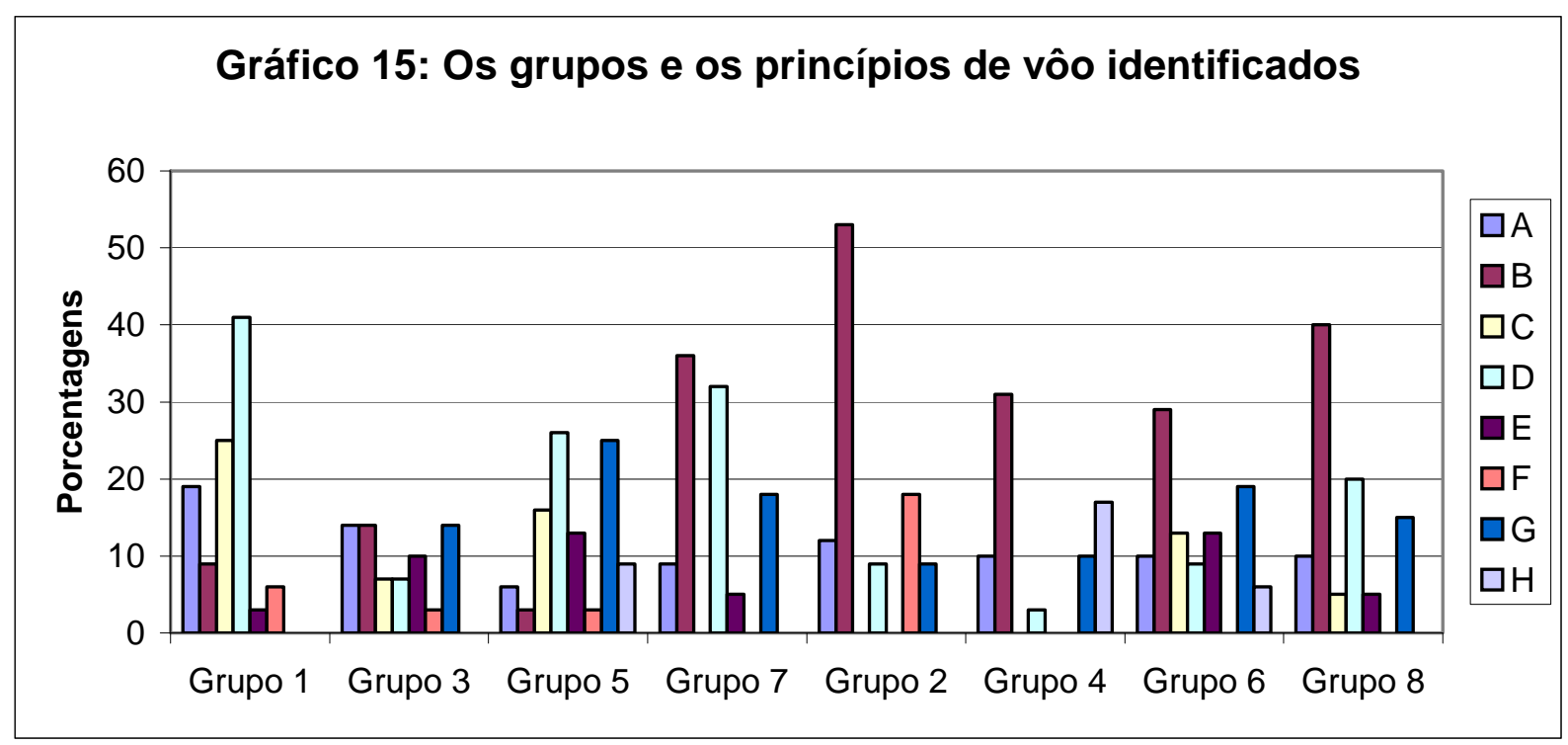

Gráfico 15: Coisas que voam, além do avião - distribuição por grupo.

Não há uma uniformidade na distribuição das respostas; os grupos são bastante diferentes, mas há uma predominância das categorias B (ausência apenas do princípio de vôo do foguete) e D (presença apenas de animais e aeroplanos). A ausência de animais nas respostas é mais acentuada na escola 
pública (grupos 3 a 8): nesta categoria (G), apenas aparelhos tecnológicos estão presentes às respostas.

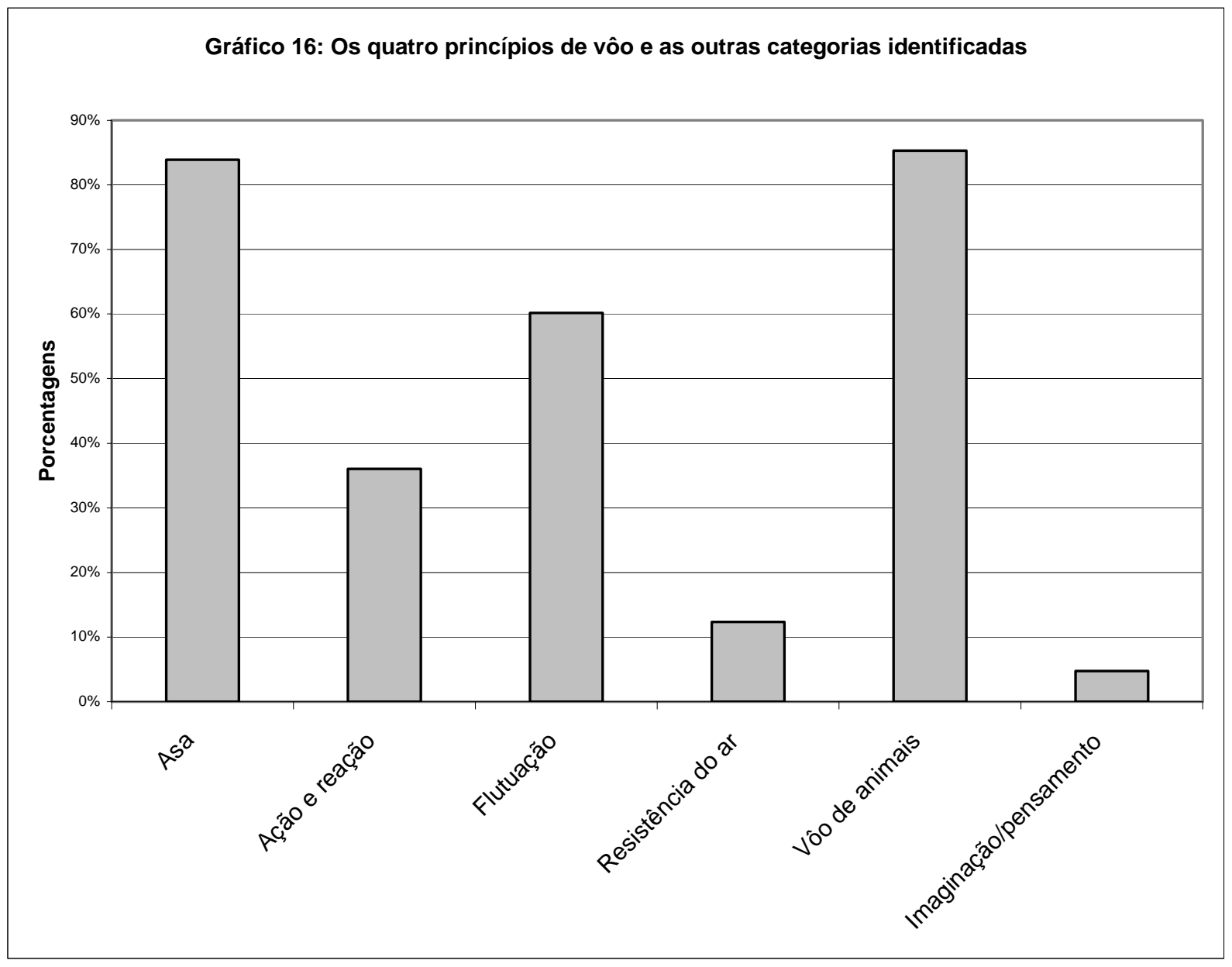

Gráfico 16: Princípios físicos que permitem que algo permaneça no ar.

Os quatro princípios de vôo podem ser identificados nas respostas dos alunos sendo o princípio da asa o mais conhecido (84\%), seguido pelo princípio de flutuação (60\%). Em outras categorias apresentadas nas respostas o vôo dos animais está fortemente presente (85\%), ainda que comparativamente em menor intensidade na escola pública que na escola privada, como realçamos anteriormente. 
- A terceira questão pede que o aluno explique o que faz o avião permanecer no ar enquanto voa, citando as partes dele que possibilitam o vôo.

O gráfico 17 apresenta as principais categorias de respostas, são elas: A - Motor e asas: explica que a força para cima (sustentação) é maior que a força para baixo.

B - Motor e asas: explica contrapondo a pressão do ar com a gravidade.

C - Motor e asas: explica utilizando apenas a pressão do ar.

D - Asas: utiliza o princípio de funcionamento das asas, indicando a parcela do ar que passa por cima das asas e a que passa por baixo.

E - Motor e asas: sem modelo explicativo.

F - A velocidade do avião.

G - Asas: ar de cima em oposição ao ar de baixo.

$\mathrm{H}$ - Motor, sem apresentar modelo explicativo.

I - Asas: sem apresentar modelo explicativo.

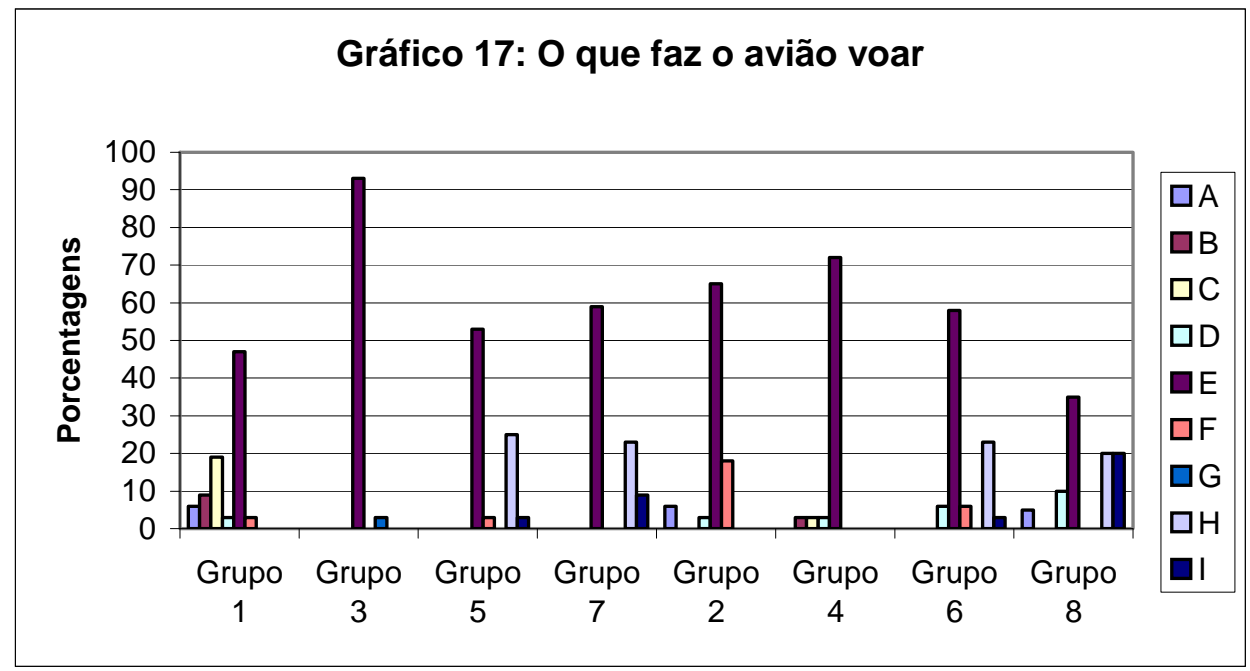

Gráfico 17: Quais partes do avião permitem que ele fique no ar - distribuição por grupos

Podemos ver um padrão bastante homogêneo, principalmente entre os grupos 5, 6, 7 e 8. Em todos os grupos, em comum, há uma predominância das 
respostas que associam ao vôo ao motor e às asas, sem apresentar um modelo explicativo (E). Podemos observar isso mais claramente no gráfico 18 abaixo, que nos possibilita uma melhor comparação por categoria.

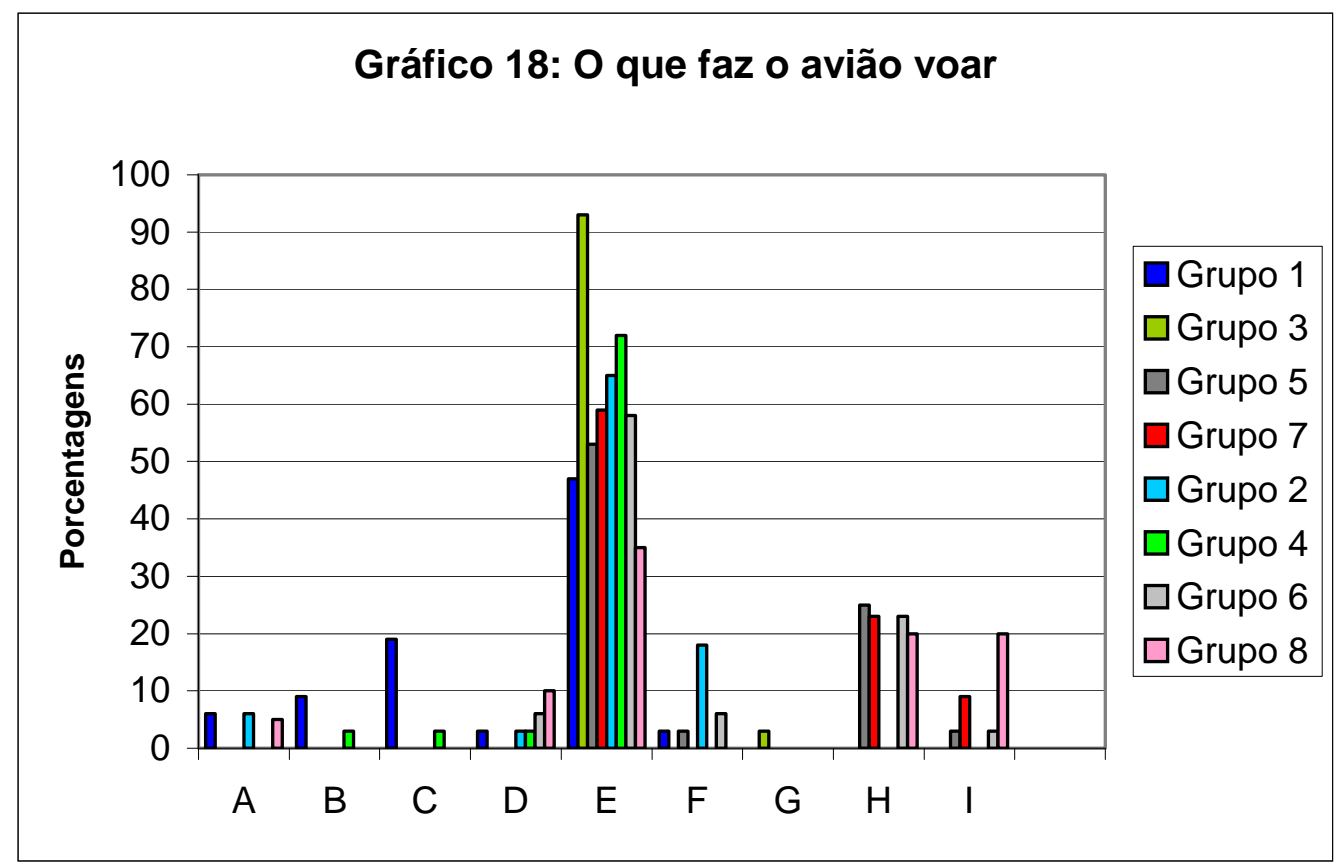

Gráfico 18: Quais partes do avião permitem que ele fique no ar - distribuição por categoria

Essa característica pode estar associada à ausência de um modelo explicativo para esse fenômeno, que não é abordado na escola, e os princípios de vôo são pouco veiculados na mídia.

- A quarta questão pede ao aluno que reflita sobre a existência de coisas capazes de voar sem um motor.

O gráfico 19 abaixo indica as principais categorias de respostas.

A - Apresenta animais, aeroplanos (asa-delta, planador), aviões de papel, pára-quedas.

B - Apresenta aeroplanos (asa-delta, planador), aviões de papel, pára-quedas.

C - Apenas animais voam sem motor. 


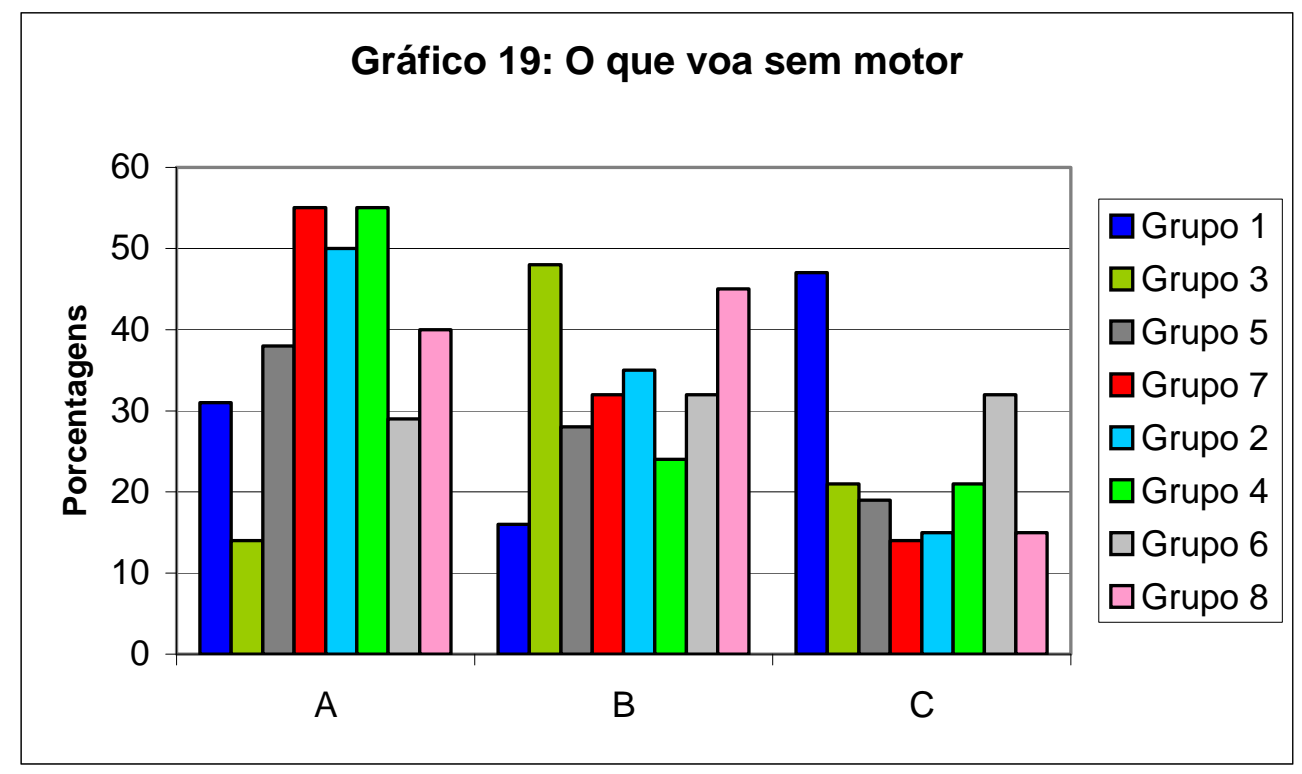

Gráfico 19: Voa sem ter motor - distribuição por categoria.

Podemos observar que os alunos têm conhecimento de que o motor não é parte essencial para voar, pois os aeroplanos sem motor, como asa-delta e planador, estão fortemente presentes nas respostas (A e B). Os alunos, entretanto, não identificam os músculos animais como motores; os animais que voam são categorizados como se não tivessem motor (A e C).

- A quinta questão pede ao aluno que reflita sobre a existência de coisas capazes de voar sem asas.

O gráfico 20 abaixo indica as principais categorias de respostas.

A - Balão ou dirigível e foguete ou bexiga.

B - Foguete ou bexiga.

C - Balão ou dirigível.

D - Balão ou dirigível e helicóptero.

E - Apenas o helicóptero 
F - Não há como voar sem asa.

G - Balão ou dirigível e pipa.

H - Abstrações: pensamento, disco-voador, super-homem

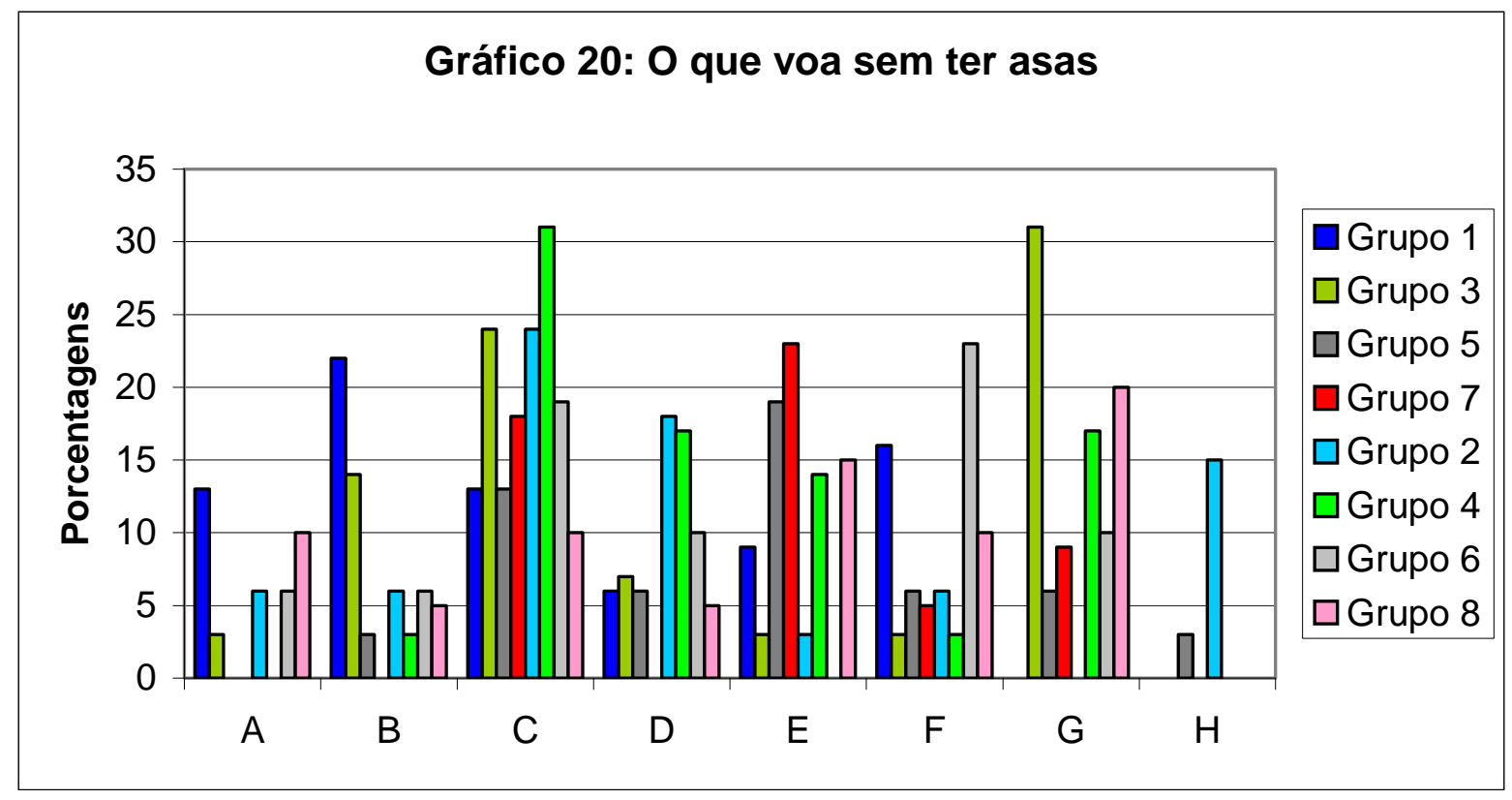

Gráfico 20: Voa sem ter asas - distribuição por categoria

Os alunos identificam aparelhos tecnológicos, como balões, dirigíveis, foguetes, e também as pipas, presentes em seu cotidiano. Interessante ressaltar que aparecem conceitos abstratos, como pensamento, e personagens de ficção, como Super-Homem, além dos polêmicos discos voadores.

Nos grupos 1, 6 e 8 é possível verificar que uma maior parte dos alunos desconhece a possibilidade de voar sem asas, principalmente os grupos 1 e 6 , em que mais de $20 \%$ dos alunos responderam que não é possível voar sem asas $(\mathrm{F})$.

Categorias bastante representativas (C, D e G) apresentam em comum o balão ou dirigível. O gráfico 21 abaixo indica a porcentagem de respostas em que o balão ou dirigível encontram-se presentes. 


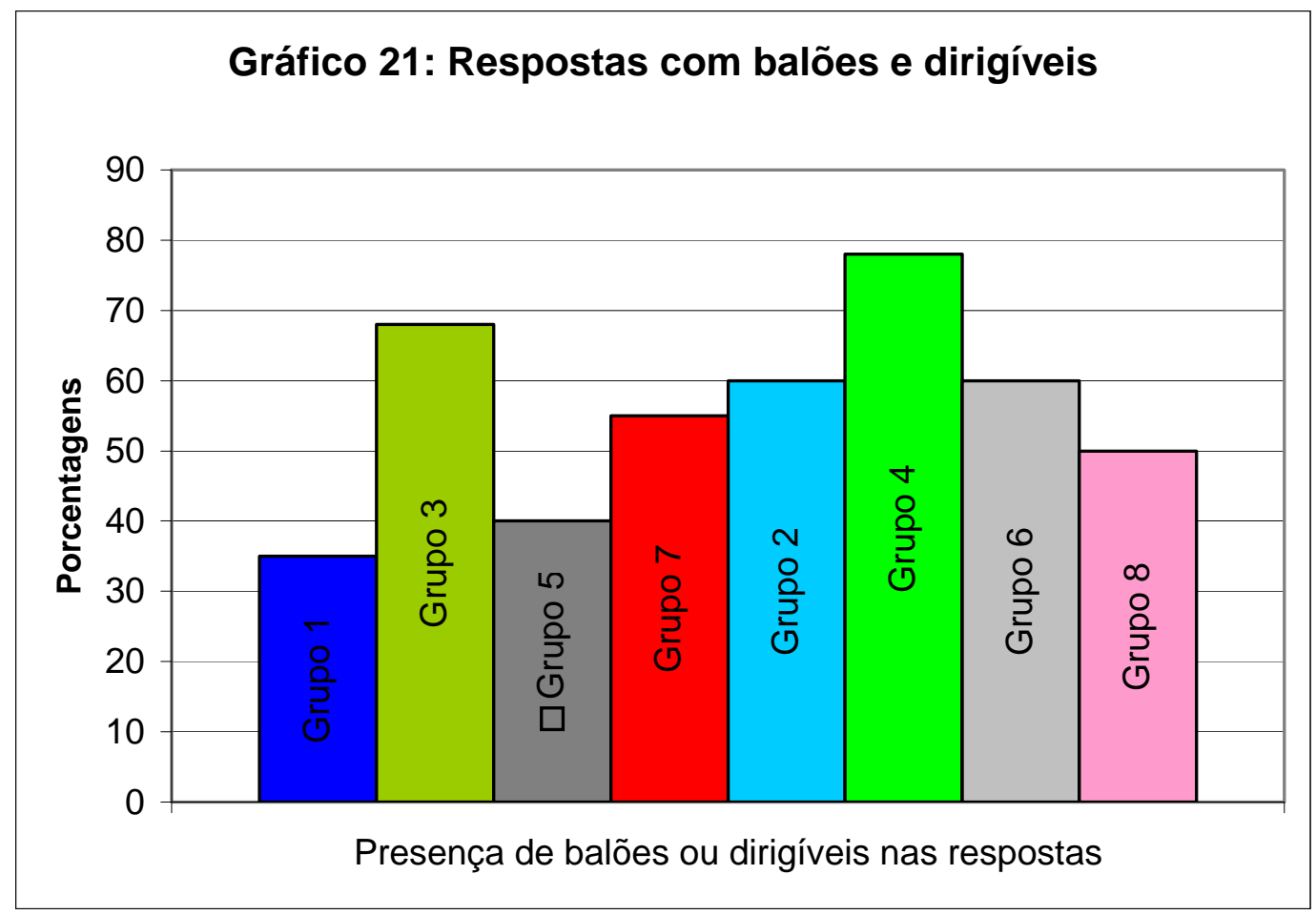

Gráfico 21: Balões e dirigíveis voam sem ter asas.

Uma característica importante identificada a partir dessa questão, a qual diferencia a escola privada (grupos 1 e 2) e a pública (grupos 3 a 8), é que na escola pública há uma forte presença da pipa nas respostas (gráfico 22), sendo que na escola privada ela quase não foi citada.

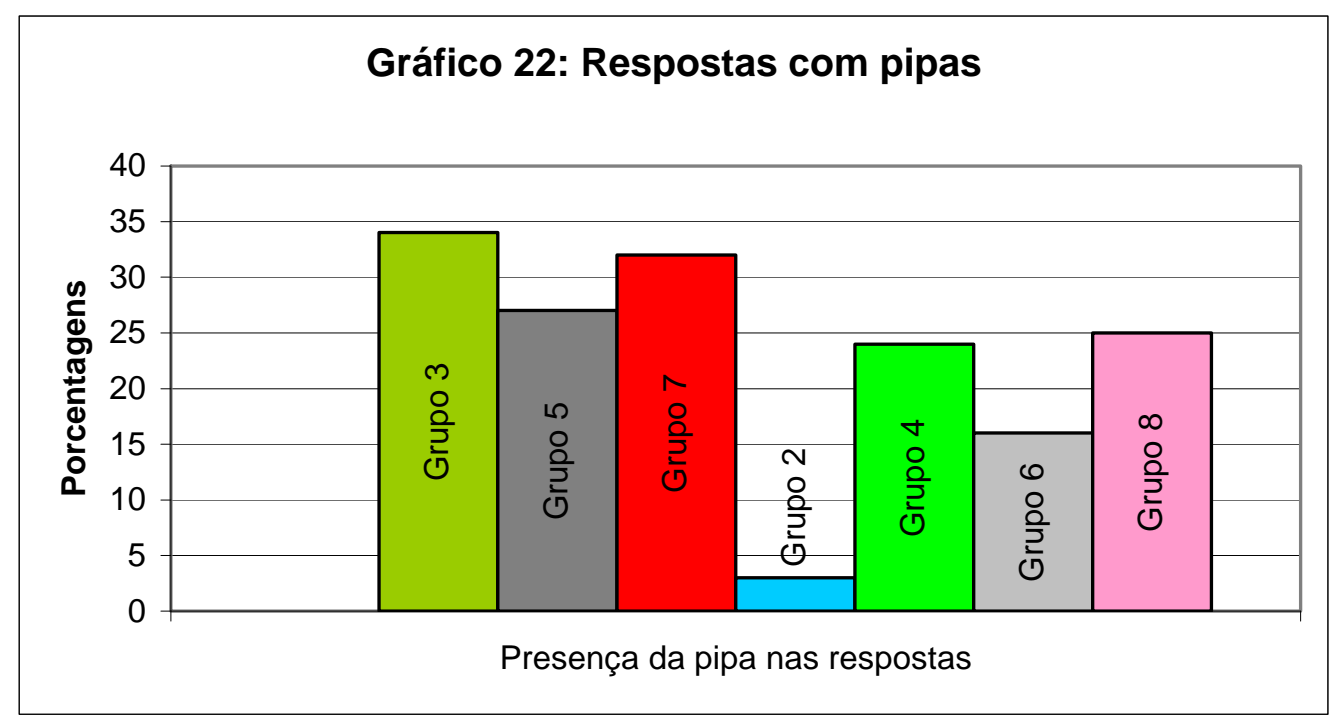

Gráfico 22: As pipas voam sem ter asas. 
Acreditamos que isso seja reflexo de conhecimentos construídos por meio das atividades lúdicas extra-escolares do cotidiano dos alunos, já que entre os alunos de baixa renda as brincadeiras de rua ainda são populares, e nas classes mais abastadas são quase inexistentes.

\section{Considerações sobre o pré-teste}

Em relação aos conhecimentos prévios sobre Aerodinâmica, a amostragem da escola pública e a da escola privada não são equivalentes, já entre os grupos de alunos da escola pública há certa equivalência. O detalhamento do gráfico 12 indica que alunos da escola pública apresentam medo de voar e uma preocupação com a questão financeira (preço da passagem), o que não foi relevante na escola privada. Há uma forte presença dos aspectos funcionais na escola pública, e em ambas as escolas o assunto mais relacionado ao avião é sua utilidade, principalmente em relação às viagens. A questão conceitual, ligada a aspectos mais gerais, como liberdade e evolução, está presente tanto na escola privada como na pública.

Em relação ao conhecimento sobre os princípios de vôo (gráfico 14), a categoria que inclui todos os princípios de vôo apresenta uma distribuição bastante homogênea em todos os grupos, aproximadamente $10 \%$ das respostas, tendo em média na escola particular um índice levemente melhor que na pública (detalhamento do gráfico 14). A categoria que apresenta ausência do princípio de vôo do foguete é a que apresenta maior número de respostas; possivelmente esse resultado seja devido aos balões de ar, ou de gás, estarem mais presentes no mundo vivencial dos alunos. Isso é reforçado pelo baixo índice da categoria na qual o aluno não menciona o balão. Outra 
categoria bastante importante é a que indica presença de animais e aeroplanos somente. A ausência de animais nas respostas é mais acentuada na escola pública.

Em todos os grupos, em comum, há uma predominância das respostas que associam ao vôo o motor e as asas, sem apresentar um modelo explicativo (gráfico 18); essa característica pode estar associada à ausência de um modelo explicativo para esse fenômeno, que não é abordado na escola, e os princípios de vôo são pouco veiculados na mídia.

Os alunos têm conhecimento de que o motor não é parte essencial para voar, pois há aeroplanos sem motor, como asa-delta e planador (gráfico 19). Os alunos, entretanto, não identificam os músculos animais como motores, os animais que voam são categorizados como se não tivessem motor.

Em relação à possibilidade de algo que não tem asas voar (gráfico 20), os alunos identificam aparelhos tecnológicos como balões, dirigíveis, foguetes, e também as pipas, presentes em seu cotidiano. Interessante ressaltar que aparecem conceitos abstratos, como pensamento, e personagens de ficção, como Super-Homem, além dos polêmicos discos voadores.

Uma característica importante identificada, a qual diferencia a escola privada e a pública, é que na escola pública há uma forte presença da pipa nas respostas (gráfico 22), sendo que na escola privada ela quase não foi citada. Acreditamos que isso seja reflexo das atividades lúdicas extra-escolares do cotidiano dos alunos. 


\section{Pós-testes}

Para análise dos pós-testes, separamos cada um dos gráficos em duas partes: a primeira, indicada pelo sufixo "a", com dados relativos aos grupos que assistiram a apenas um dos audiovisuais; e a segunda parte, indicada pelo sufixo "b", com análise dos grupos que assistiram aos dois vídeos. A análise comparativa entre a $3 .^{\mathrm{a}}$ e a $4 .^{\mathrm{a}}$ etapas apontará qual a influência da inversão da ordem da apresentação dos pós-testes, e quais elementos sobre a contribuição de cada vídeo ela revela. As questões de números sete e doze dos pós-testes não farão parte da análise realizada nesse trabalho.

Os dados a seguir serão apresentados seguindo a ordem iniciada por todos os grupos ímpares, seguidos de todos os grupos pares. Os grupos ímpares assistiram a "Beakman" e os pares a "O Professor" na $3^{a}$ etapa, e a ambos os vídeos na 4. ${ }^{a}$ etapa. Essa análise permite identificar diferenças de apreensão dos conteúdos específicos dos audiovisuais e possíveis cooperações.

\section{Análise das respostas às questões elaboradas como primeiro pós-teste}

- A sexta questão verifica se o aluno é capaz de identificar, dentre uma lista de objetos que voam, quais deles voam pelo mesmo princípio do avião. Estão nesta lista objetos que voam por quatro princípios em que baseio a criação das categorias de análise (ação e reação; asas; flutuação por empuxo; resistência do ar).

O gráfico 23 indica percentualmente as principais categorias de respostas.

A - Avião de papel, pipa, asa-delta, helicóptero e pára-quedas.

B - Avião de papel, asa-delta e helicóptero. 
C - Avião de papel, helicóptero.

D - Pipa, asa-delta, helicóptero.

E - Avião de papel, asa-delta, pára-quedas.

F - Avião de papel e asa-delta.

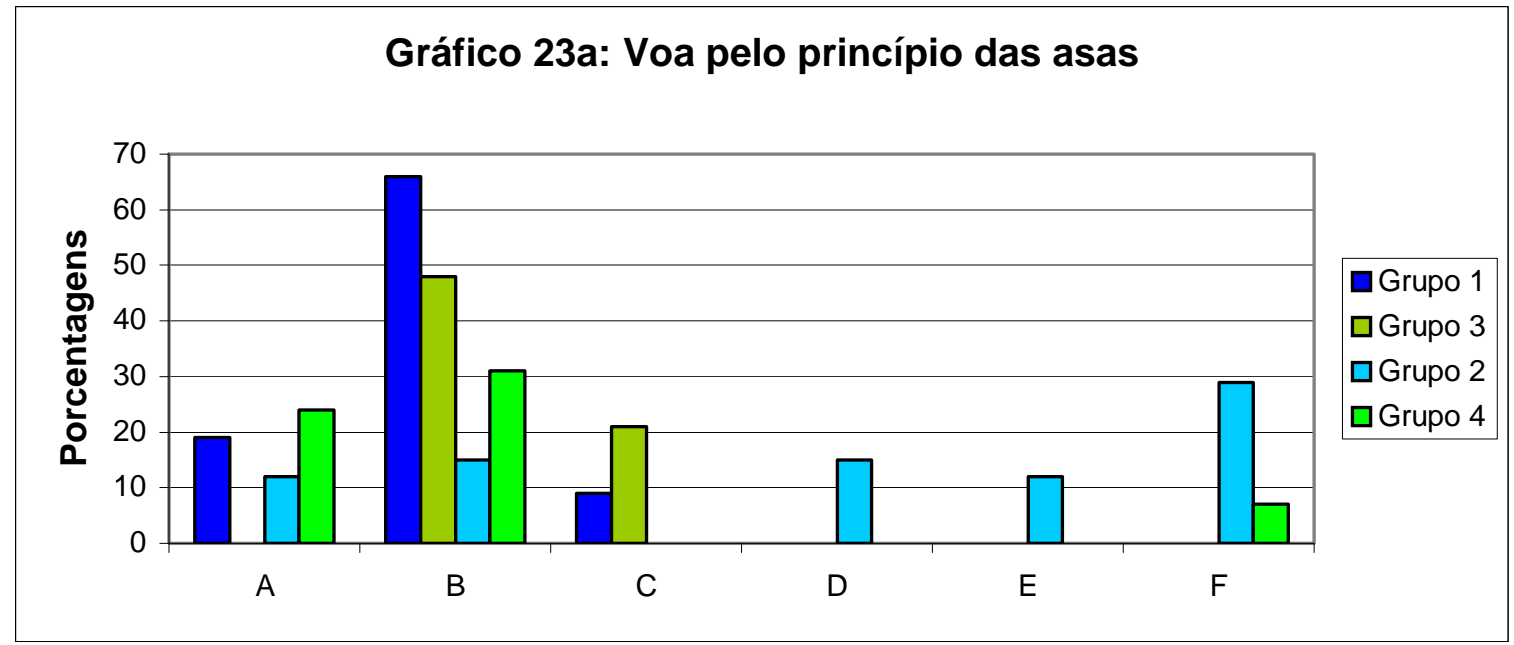

Gráfico 23a: Que objetos voam pelo princípio das asas - Os alunos assistiram a apenas um vídeo, os grupos ímpares a "Beakman” e os pares a “O Professor”.

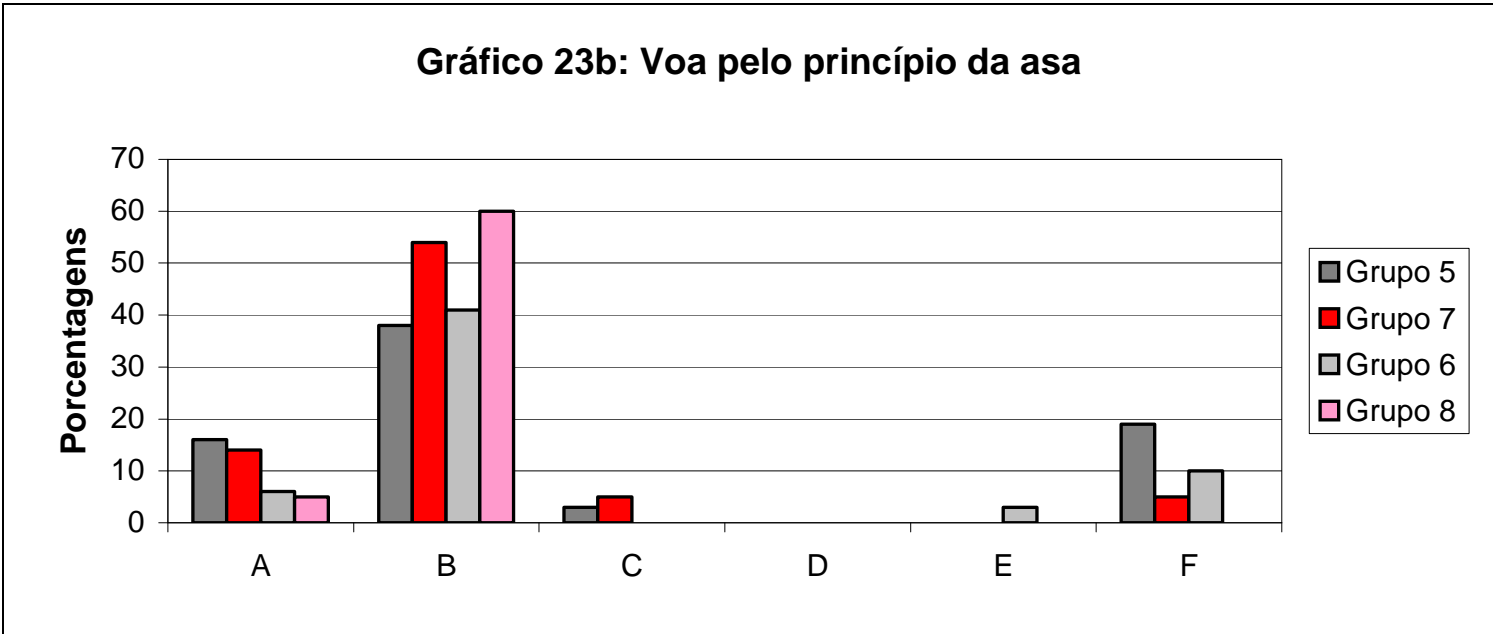

Gráfico 23b: Que objetos voam pelo princípio das asas - Os alunos assistiram aos dois vídeos; para os grupos ímpares a seqüência foi "Beakman” - “O Professor”, para os pares a ordem foi a inversa.

As categorias mais representativas, A e B, apresentam os principais elementos que voam pelo mesmo princípio que o avião, excetuando-se o avião de papel, que está relacionado à resistência do ar, como a pipa e o páraquedas, mas esse não foi um assunto abordado nos vídeos, além de o próprio 
nome "avião de papel" sugerir que o princípio seja o mesmo. A pipa e o páraquedas são apresentados na literatura, em alguns casos, pelo princípio das asas. Vemos pelo gráfico 23a que os alunos que assistiram apenas ao vídeo "Beakman" apresentam um desempenho melhor, com maior índice de respostas identificadas na categoria B. Um padrão mais homogêneo pode ser observado no gráfico 23b, após a exibição de ambos os vídeos, mantendo-se a maior porcentagem na categoria $B$ e em seguida na categoria $A$.

- A oitava questão verifica se o aluno consegue extrapolar e reconhecer a forma das asas num carro, que apresenta um formato semelhante, reto na parte de baixo e arredondado na parte de cima.

A - Sim, o carro tem o formato de uma asa.

B - Não, apesar do formato adequado não há como permanecer em vôo.

C - Não, ele não apresenta o princípio das asas.

D - Não, pois para voar é preciso ter asas.

E - Não, sem justificativa.

F - Cita o aerofólio, que é uma asa invertida pressionando o carro para o chão. 


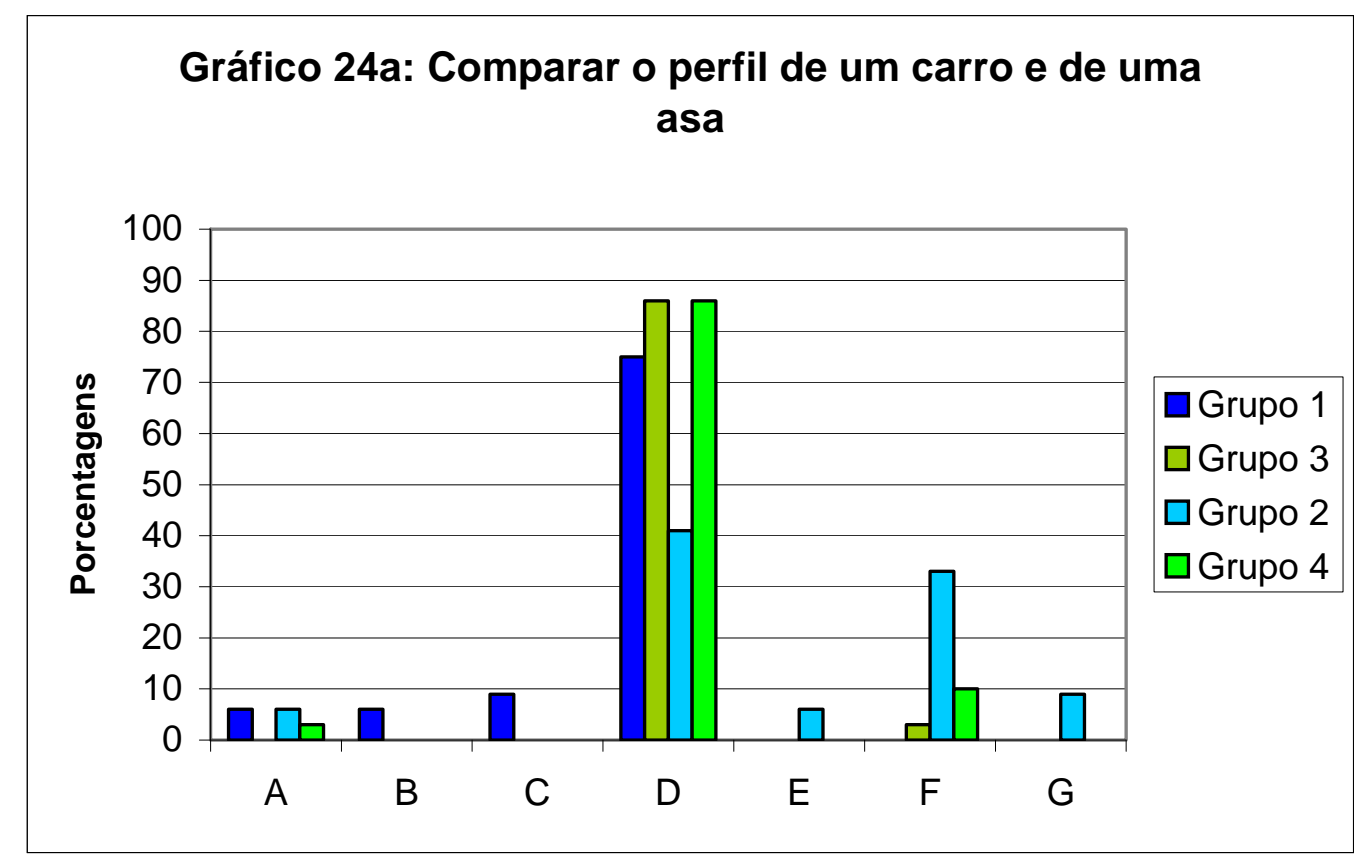

Gráfico 24a: Identificar a semelhança entre o perfil da asa e de um carro - Os alunos assistiram a apenas um vídeo, os grupos ímpares ao "Beakman” e os pares ao “O Professor”.

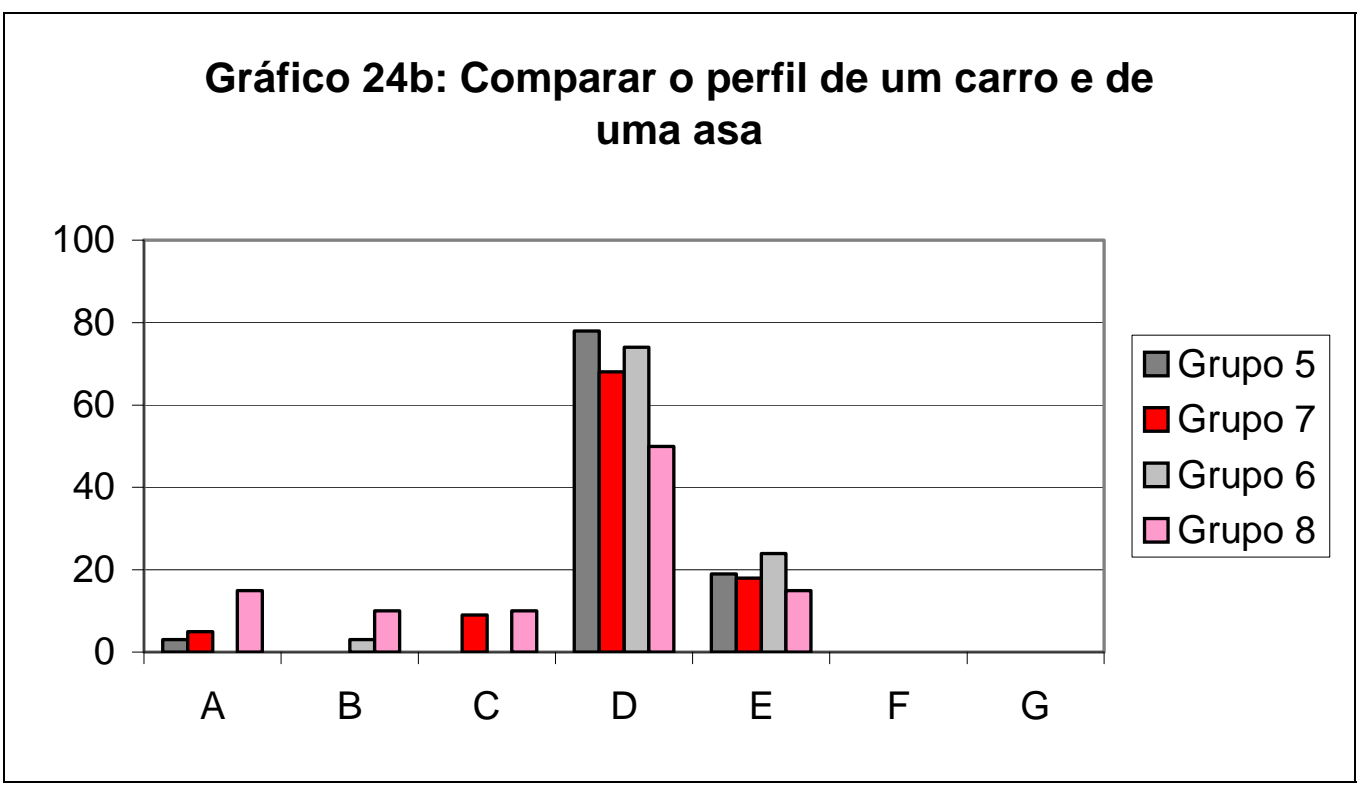

Gráfico 24b: Identificar a semelhança entre o perfil da asa e de um carro - Os alunos assistiram aos dois vídeos; para os grupos ímpares a seqüência foi “Beakman” - “O Professor”, para os pares a ordem foi a inversa.

Podemos verificar que essa extrapolação — reconhecer semelhanças no perfil de uma asa e de um carro - necessita de um grau maior de abstração, sendo bastante difícil: menos de $10 \%$ dos alunos atingiram esse entendimento 
(A e B), a grande maioria (D) ainda afirma que para um carro voar precisa ter asa, mesmo após assistir aos dois audiovisuais.

O aerofólio utilizado em carros de corrida é abordado em "O Professor". Uma representativa parte dos alunos que assistiram a "Beakman", cerca de $30 \%$ no grupo 2 e $10 \%$ no grupo 4 , citam a presença do aerofólio pressionando o carro para o chão. Os alunos não identificaram a semelhança entre o formato do carro e o de uma asa, apenas enfocando o uso do aerofólio para mantê-lo no chão (F).

É possível identificar um aumento significativo de respostas sem justificativa, após a exibição dos dois vídeos. Possivelmente, por terem mais informações e estarem mais seguros de que não há semelhanças entre os formatos de uma asa e de um carro, os alunos ficam mais à vontade para negar sem se justificar, já que um carro não deve voar; ele é projetado para permanecer rente ao chão.

- A nona questão verifica que alterações o aluno propõe para melhorar o vôo de um avião de papel.

O gráfico 25 abaixo indica as principais categorias de respostas.

A - Mudar a aerodinâmica da asa, fazendo uma envergadura.

B - Inclinar a asa, aumentando a pressão em baixo.

C - Fornecer mais vento, com um ventilador, ou soltando o avião contra o vento.

D - Acrescentou coisas do senso comum, como dobrar a ponta da asa, fazer um bico fino, usar papel mais leve, aumentar a asa, colocar motor no avião. 


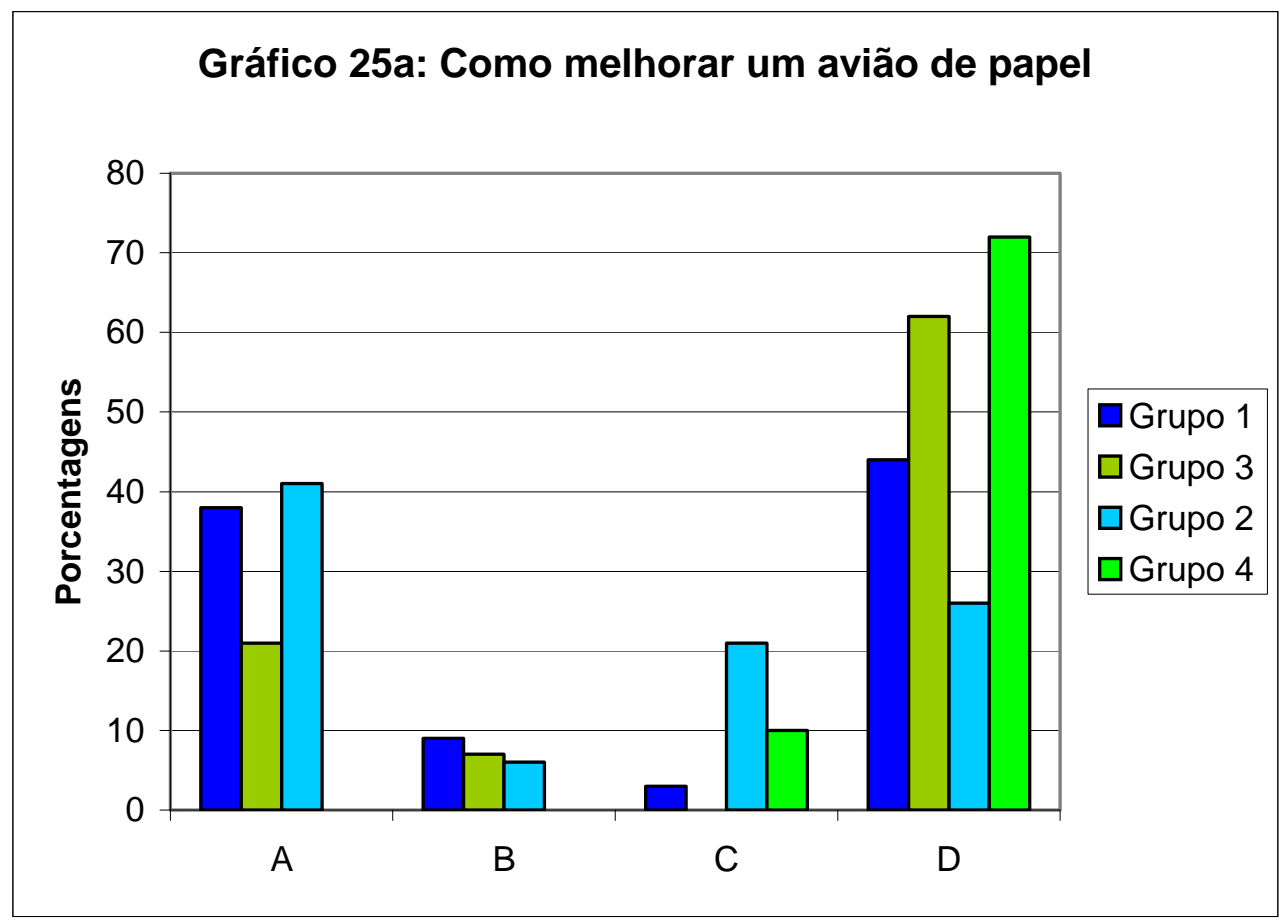

Gráfico 25a: Como se pode melhorar o vôo de um avião de papel - Os alunos assistiram a apenas um vídeo, os grupos ímpares a "Beakman” e os pares a "O Professor".

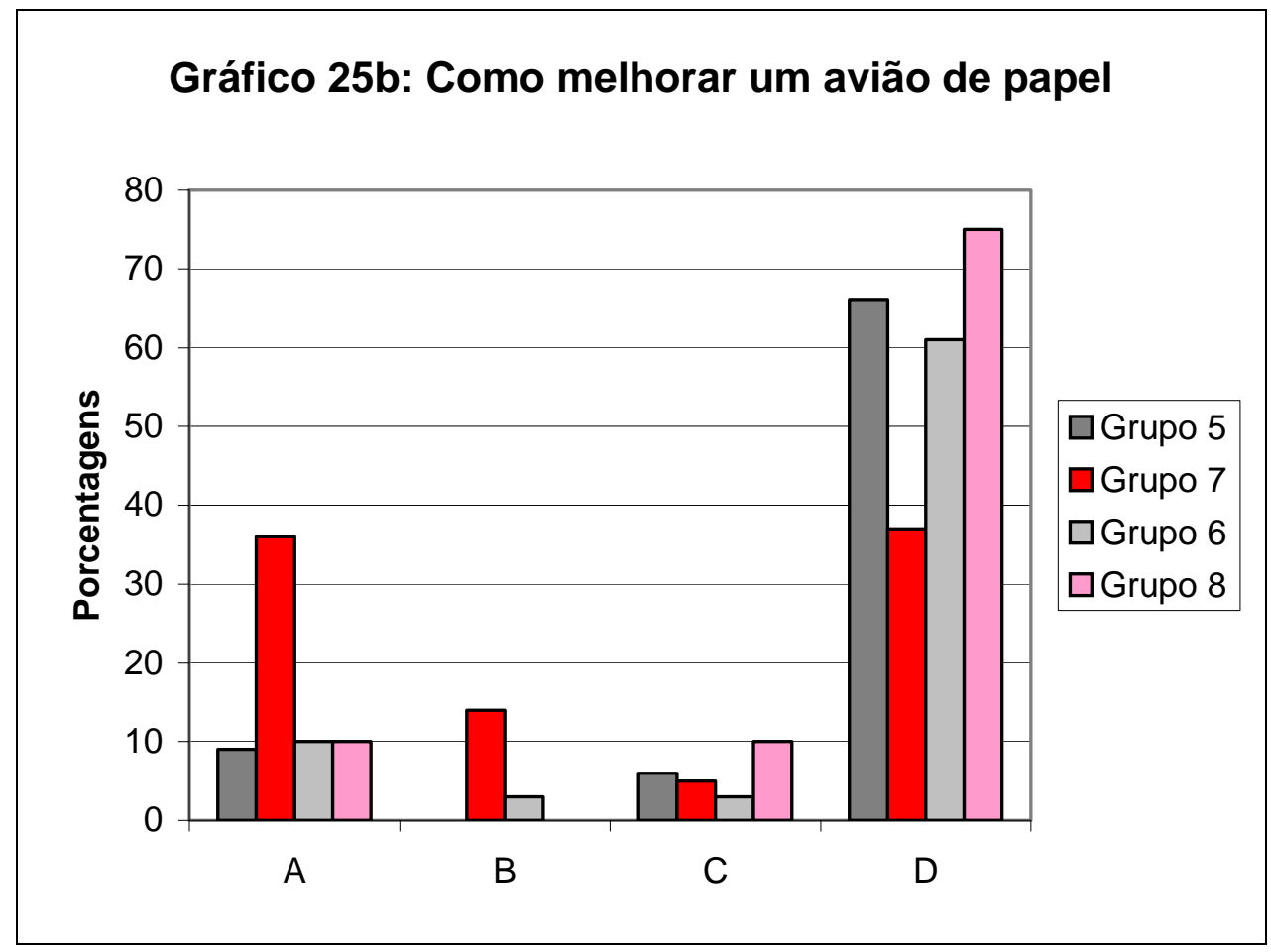

Gráfico 25b: Como se pode melhorar o vôo de um avião de papel - Os alunos assistiram aos dois vídeos; para os grupos ímpares a seqüência foi “Beakman - O Professor”, para os pares a ordem foi a inversa. 
Os alunos da escola particular (grupos 1 e 2 ) apresentam um desempenho significativamente melhor, no que tange ao conhecimento científico (A). Cerca de $40 \%$ dos alunos da escola particular alteram o formato da asa do avião.

Em ambas as escolas (particular e pública) verifica-se uma forte influência dos conhecimentos do senso comum; esses dois resultados independem do vídeo apresentado, ainda que o grupo 2 apresente a menor influencia do senso comum, enquanto o grupo 4 apresenta a maior, sendo em média semelhante o desempenho.

Se comparados os desempenhos das escolas públicas, por meio dos gráficos $25 a$ e $25 b$, vemos um desempenho mais homogêneo e melhor dos grupos 5, 6, 7 e 8, em relação aos grupos 3 e 4, mas claramente ainda inferior ao desempenho da escola privada, grupos 1 e 2 .

Já a categoria de análise C está ligada à abordagem dos conteúdos dos vídeos. "O Professor" apresenta o exemplo de um compressor para mostrar o funcionamento da asa; nele, mostra-se a força do vento como um elemento importante, por isso apresenta porcentagem maior nos grupos 2 e 4 , o que pode ser identificado também nos grupos que assistiram aos dois vídeos. 
Considerações sobre as questões elaboradas para o $1 .^{\circ}$ pós-teste na $3 .^{a}$ etapa e utilizadas como $2 .^{\circ}$ pós-teste na $4 .^{a}$ etapa

Os alunos, em sua maioria, identificam outros aparelhos tecnológicos, como asa-delta, helicóptero e pára-quedas, que apresentam o mesmo princípio de vôo do avião. Uma característica relevante é que o avião de papel, sem envergadura na asa, não voa pelo mesmo princípio da asa, pois seu vôo está relacionado à viscosidade do ar, assim como a pipa e o pára-quedas, embora esses dois últimos também sejam apresentados na literatura com modelos explicativos de vôo baseado no princípio da asa. Esse não foi um assunto abordado nos vídeos, sendo esse tipo de análise bastante sofisticada. Essa associação é reforçada pelo nome "avião de papel", que sugere o mesmo princípio do avião.

O vídeo "Beakman", por abordar o conceito de asa rotatória ao falar do helicóptero, apresentou desempenho superior (gráfico 23a); uma maior porcentagem de alunos identifica o mesmo princípio de vôo no avião e no helicóptero. Já "O Professor" não aborda esse conceito, mantendo categorias representativas que não incluem o conceito de asa rotatória. Esse desempenho superior também é identificado com os dois vídeos, o que pode ser identificado no gráfico $23 b$.

Em relação à extrapolação do conceito de asa (gráfico 24), abstraindose a funcionalidade e atendo-se à forma (a forma do perfil de um carro é semelhante ao perfil de uma asa), podemos verificar que é preciso um grau muito grande de abstração, o que é bastante difícil para os alunos do Ensino Médio. Menos de 10\% dos alunos atingiram esse entendimento; a grande 
maioria ainda afirma que para um carro voar é preciso ter asas, independentemente de assistir a um ou aos dois vídeos.

Em relação à aplicação dos conceitos abordados nos vídeos sobre o princípio da asa, para melhorar o vôo de um avião de papel (gráfico 25), os alunos da escola particular apresentam um desempenho significativamente melhor, no que tange à aplicação de conceitos científicos para melhorar o avião de papel: cerca de $40 \%$ dos alunos da escola particular alteram o formato da asa do avião de papel, criando nela uma envergadura, deixando-a com o perfil de uma asa de avião. Os alunos da escola particular tiveram desempenho melhor que alunos de escola pública que assistiram aos dois vídeos. Essa resposta mais científica, no entanto, pode estar ligada ao sistema de avaliação utilizado em escolas privadas, porquanto os alunos "sabem" o que o professor espera deles como resposta, podendo tal resultado estar viciado, nesse sentido. Em ambas as escolas (particular e pública), verifica-se uma forte influência dos conhecimentos do senso comum, sendo que esses resultados independem do vídeo apresentado.

Outra característica que apresenta padrões distintos no pós-teste, a qual está ligada à abordagem dos conteúdos nos vídeos, é a questão da intensidade do vento para o vôo do avião: "O Professor" apresenta como exemplo a utilização de um compressor para mostrar o funcionamento da asa, apresentando-se a "força do vento" como um elemento importante para o avião voar. Os dois grupos de pesquisa refletem essa característica no pós-teste; uma representativa parte dos alunos que assistiram a "O Professor" indica a "força do vento" como fator para a melhora do vôo do avião de papel, ocorrendo o mesmo com alunos que assistiram aos dois vídeos. 
Análise das respostas às questões elaboradas para $02 .^{\circ}$ pós-teste na $3 .^{a}$ etapa e utilizadas como $1 .^{\circ}$ pós-teste na $4 .^{a}$ etapa

Para análise dos pós-testes, separamos cada um dos gráficos em duas partes: a primeira, indicada pelo sufixo "a", com dados relativos aos grupos que assistiram a apenas um dos audiovisuais; e a segunda parte, indicada pelo sufixo "b", com análise dos grupos que assistiram aos dois vídeos.

- A décima questão enfoca os principais componentes que permitem o vôo de aviões (cabine, motor, asa), pedindo que se explique a função deles. As porcentagens de respostas englobadas nas categorias abaixo são apresentadas no gráfico 26 :

A - Asa associada ao vôo, com modelo explicativo. Motor associado à velocidade. Cabine associada ao controle.

B - Cabine associada à redução do atrito (formato).

C - Asa associada ao equilíbrio/estabilidade.

D - Asa associada ao vôo. Motor para dar a direção para o avião. Cabine para controle.

E - Asa associada ao vôo. Motor para fazer o avião subir, levantar vôo. 
Gráfico 26a: Componentes de um avião e suas funções

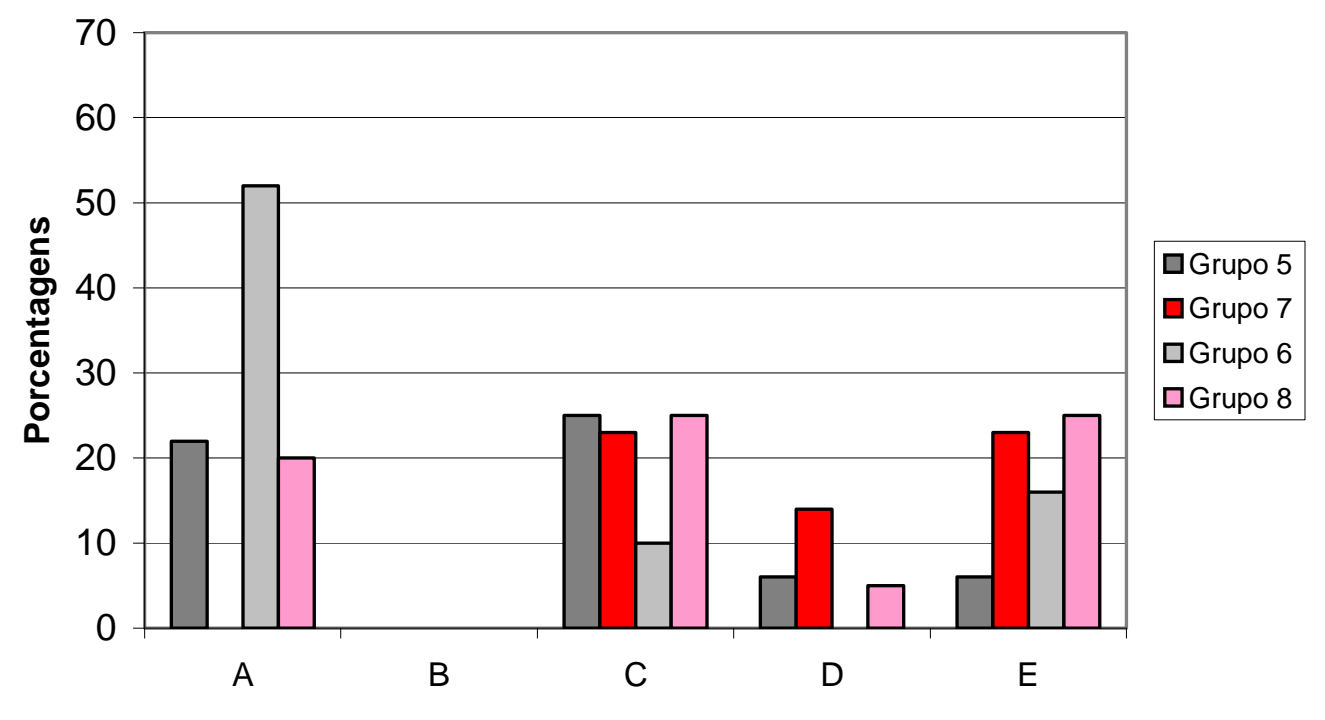

Gráfico 26a: Principais componentes de um avião e suas funções no vôo - Os alunos assistiram a apenas um vídeo, os grupos ímpares a “Beakman” e os pares a “O Professor”.

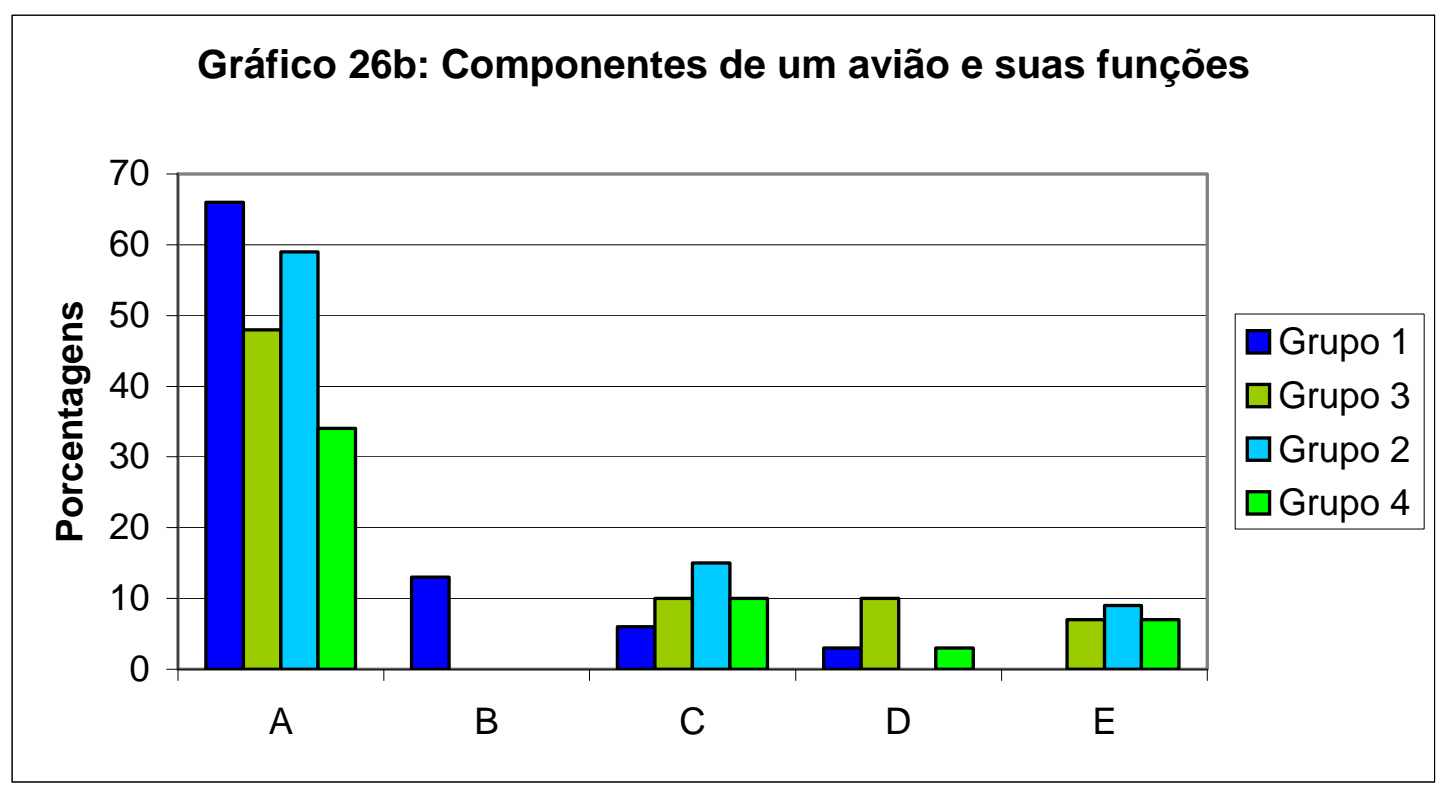

Gráfico 26b: Principais componentes de um avião e suas funções no vôo - Os alunos assistiram aos dois vídeos; para os grupos ímpares a seqüência foi “Beakman” _“O Professor”, para os pares a ordem foi a inversa.

Podemos identificar um significante avanço ao comparar os gráficos $26 a$ e 26b, pois os alunos que assistiram aos dois vídeos tiveram um desempenho 
significativamente melhor, e atingiram um conhecimento científico; houve um melhor desempenho na escola privada, independente da ordem.

Nos casos em que é possível identificar pequena relevância na ordem, parece ter melhores resultados a seqüência iniciando-se com "Beakman" (grupos ímpares), porém os resultados da terceira etapa em que os alunos só assistiram a um dos vídeos (gráfico 26a) mostram que a ordem pode ser indiferente, visto que inicialmente "O professor" apresentou melhor resultado, mas no final, após assistirem aos dois vídeos (4. a etapa, gráfico 26"b"), os alunos que assistiram a apresentação na ordem "Professor/Beakman" passaram a apresentar um desempenho levemente inferior aos que assistiram a ordem "Beakman/Porfessor".

O gráfico 26b reforça que o desempenho dos dois vídeos é melhor, trazendo indícios da cooperação de seus elementos.

- A décima primeira questão enfoca os principais componentes que permitem o vôo de helicópteros (cabine, motor, hélice de cima (asa rotatória) e hélice da cauda do helicóptero), pedindo que se explique a função deles. A - Modelo explicativo da hélice como asa rotatória (presente em "Beakman"). B - Modelo explicativo da hélice como pás de um ventilador (presente em "O Professor" - par "ação—reação").

C - Hélice de cima para manter no ar e hélice de trás para dar a direção e controlar a rotação.

D - Hélice de cima para manter no ar e hélice de trás para impulsionar para a frente, direcionando o helicóptero para andar reto. 


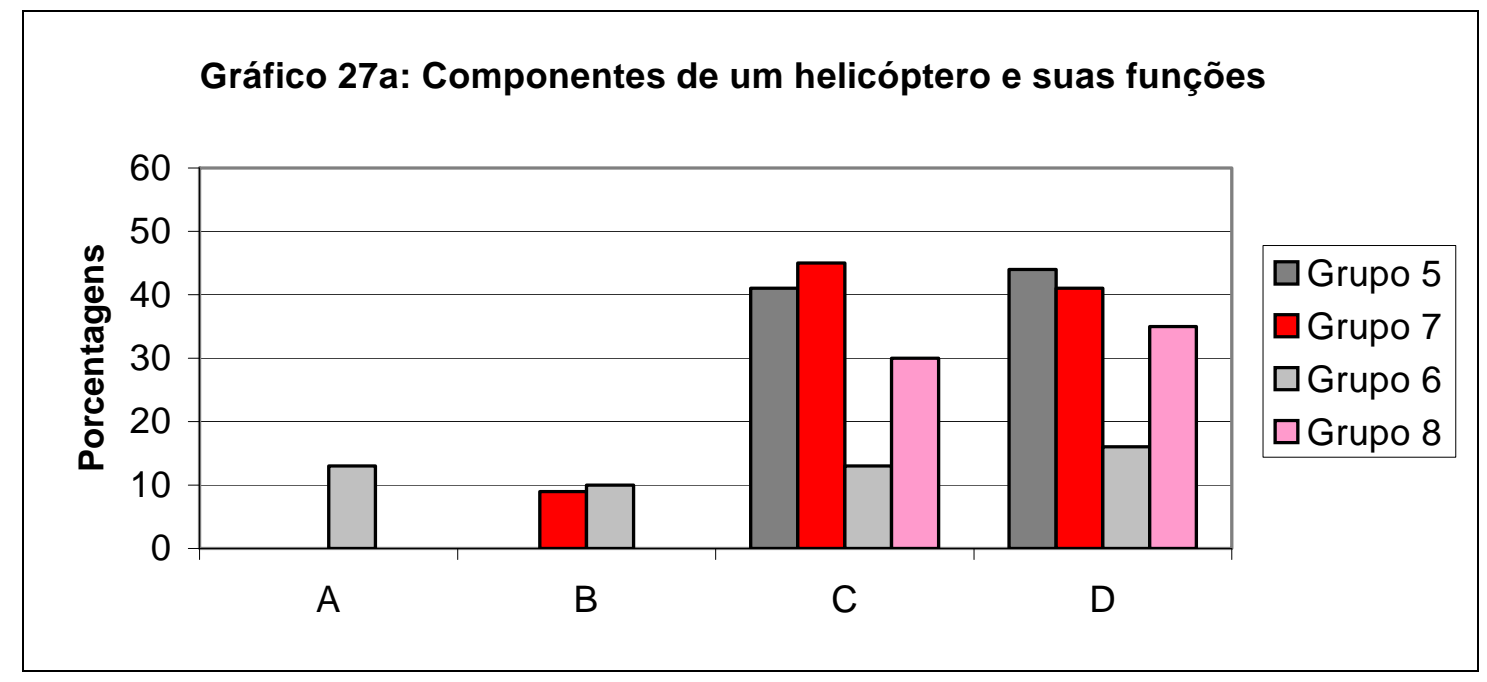

Gráfico 27a: Principais componentes de um helicóptero e suas funções no vôo - Os alunos assistiram a apenas um vídeo, os grupos ímpares a "Beakman” e os pares a “O Professor”.

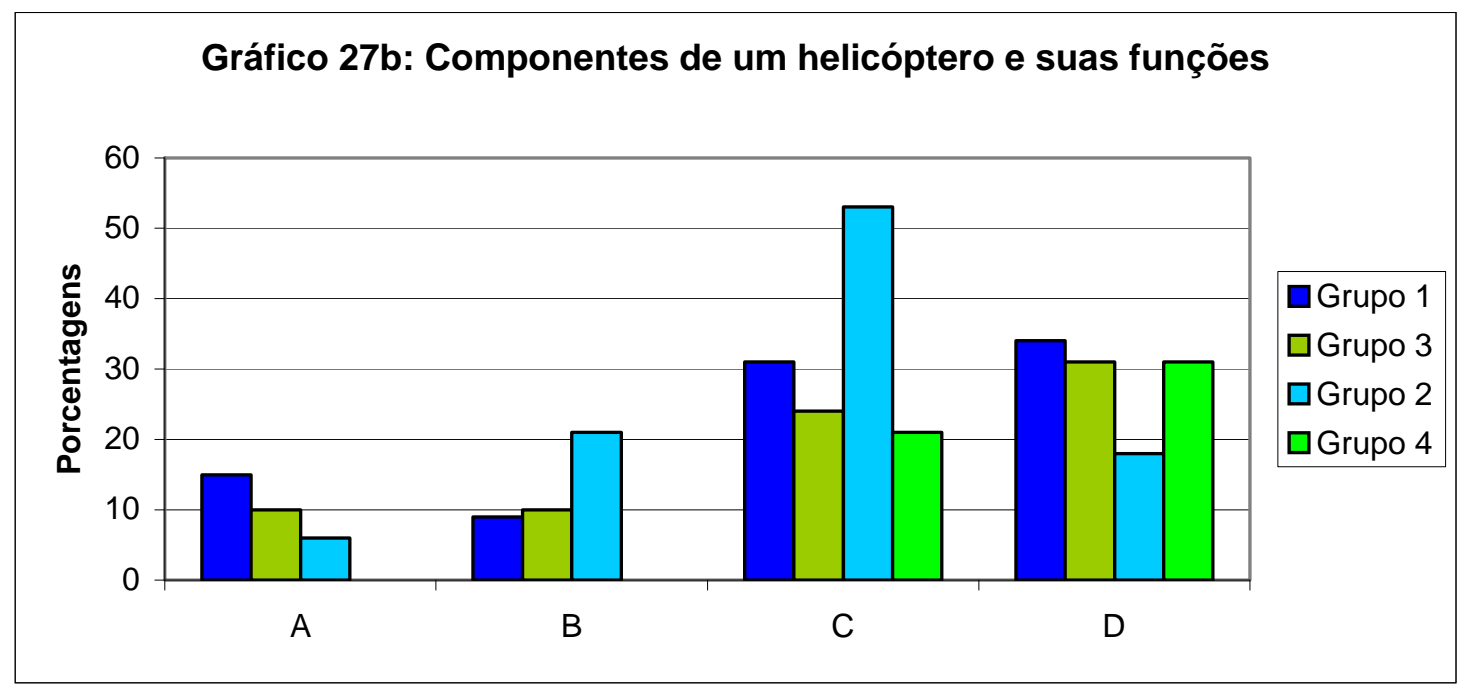

Gráfico 27b: Principais componentes de um helicóptero e suas funções no vôo - Os alunos assistiram aos dois vídeos; para os grupos ímpares a seqüência foi "Beakman” - “O Professor”, para os pares a ordem foi a inversa.

Comparando os gráficos $27 \mathrm{a}$ e $27 \mathrm{~b}$, vemos que os alunos que assistiram aos dois vídeos tiveram um desempenho significativamente melhor. Em relação à categoria em que se apresenta um modelo explicativo para a hélice, a categoria $A$, houve um melhor desempenho para os grupos que assistiram inicialmente a "Beakman" (grupos ímpares), mas os resultados da terceira etapa (gráfico 27a) mostram que a ordem pode ser indiferente. Comparando os 
gráficos, também podemos identificar uma melhora na redução de respostas presentes na categoria $D$ (que erroneamente afirmam que a hélice da cauda não impulsiona o helicóptero para frente). Ao mesmo tempo, vemos o aumento de respostas presentes na categoria $\mathrm{C}$, que vincula a hélice de cauda à rotação do helicóptero, o que foi discutido em "Beakman", indicando uma contribuição desse vídeo. Assim, o gráfico 27b mostra que o desempenho dos dois vídeos é melhor, trazendo indícios da cooperação de seus elementos.

- A décima terceira questão é semelhante à $8 .^{a}$ questão do outro pósteste. Ela verifica se o aluno é capaz de extrapolar e reconhecer a forma da asa num telhado que sai voando com um vento muito forte, ou se o aluno é capaz de abstrair e identificar semelhanças no perfil do telhado de uma casa e do perfil de uma asa.

A - Identifica o princípio da asa no telhado.

B - É o mesmo princípio do avião, a pressão em baixo das telhas aumenta e joga-as para fora, arrastando-as.

C - É o mesmo princípio do avião, mas sem justificativa.

D - Não é o mesmo princípio, a força do vento é maior que a força que prende as telhas, arrancando-as.

E - Não é o mesmo princípio, pois avião tem asas e a telha não. 


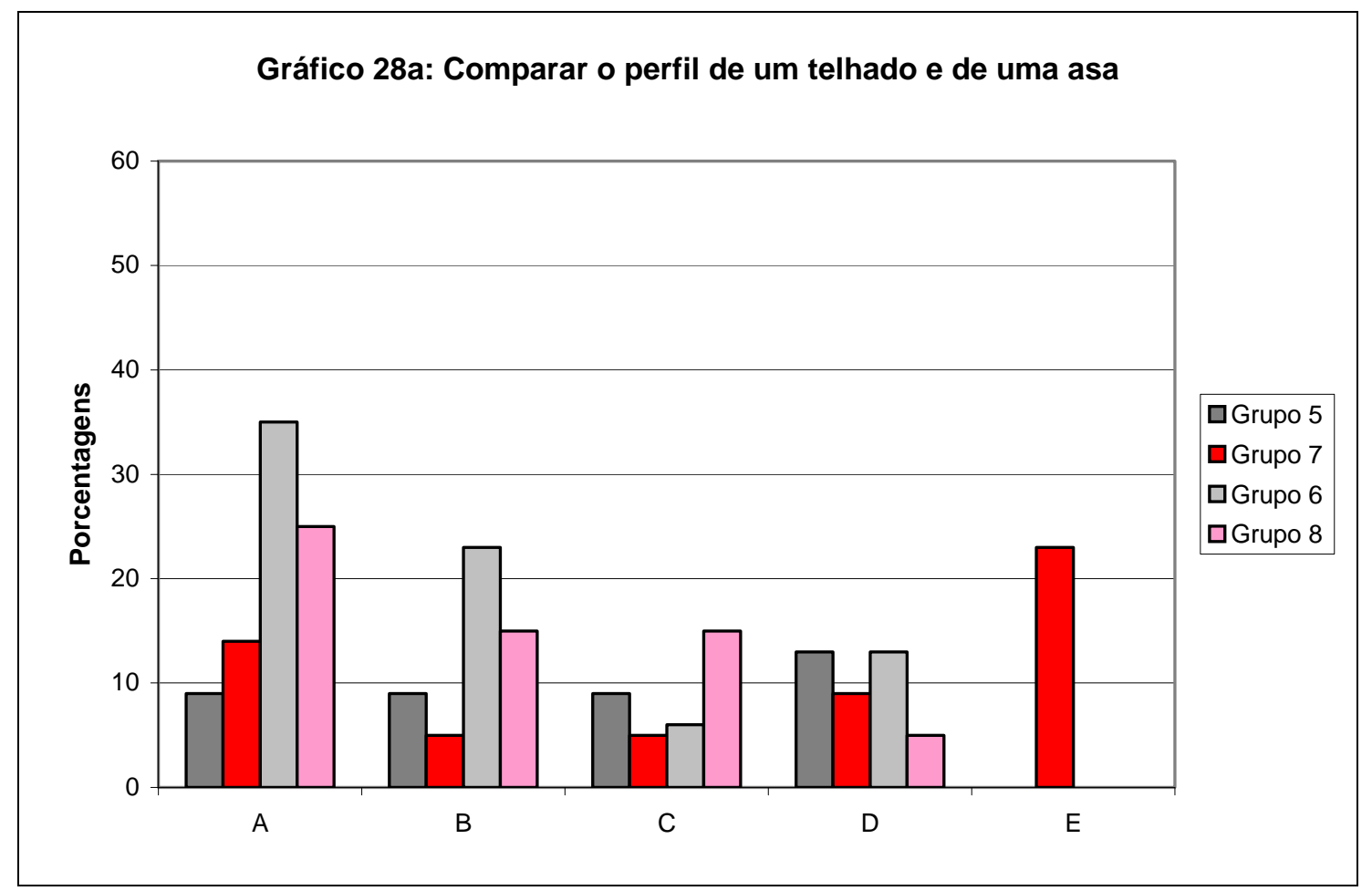

Gráfico 28a: Identificar a semelhança entre o perfil da asa e de um carro - Os alunos assistiram a apenas um vídeo, os grupos ímpares a “Beakman” e os pares a “O Professor”.

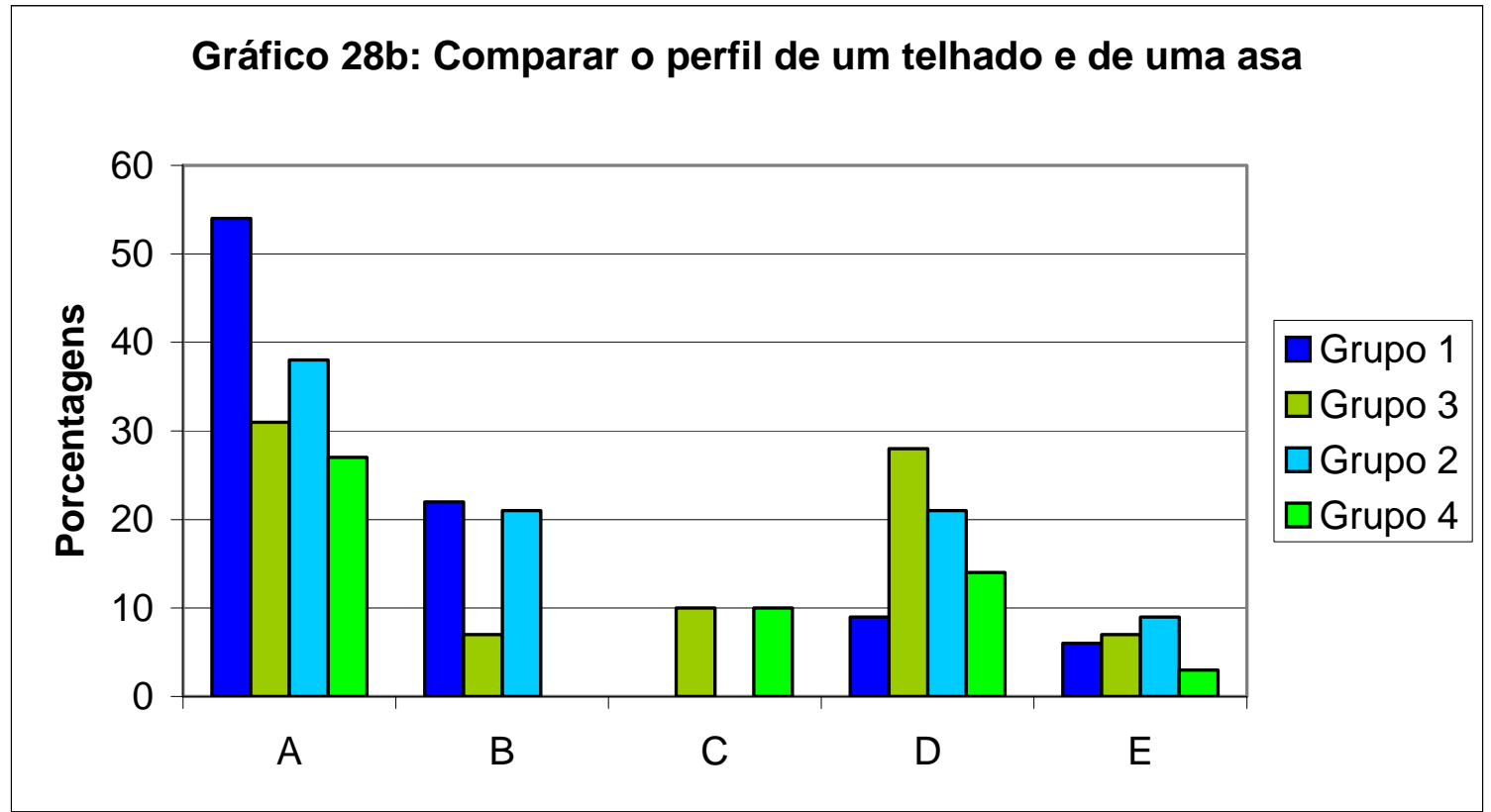

Gráfico 28b: Identificar a semelhança entre o perfil da asa e de um carro - Os alunos assistiram aos dois vídeos; para os grupos ímpares a seqüência foi “Beakman” - “O Professor”, para os pares a ordem foi a inversa.

Em primeiro lugar, identificamos que é mais fácil a abstração necessária à comparação do perfil da asa de avião e do telhado de uma casa, do que a 
abstração necessária para comparar a asa e um carro, a qual foi proposta na questão 8 do outro pós-teste, tendo um desempenho muito melhor do que nele, se forem comparados os gráficos 24 e 28.

Identificamos no gráfico 28 que após assistir aos dois vídeos (gráfico 28b) o desempenho em identificar o princípio científico da asa num telhado que sai voando durante uma ventania é significativamente maior que após assistir apenas a um vídeo. Também pode ser identificado um melhor desempenho na escola privada.

- A décima quarta questão compara o que acontece com um dirigível, um avião e um helicóptero ao parar o motor.

A - O dirigível continua na mesma altura, o helicóptero cai antes do avião.

B - Os três caem, na seqüência: primeiro o helicóptero, depois o avião e por fim o dirigível.

C - Primeiro cai o helicóptero, seguido do dirigível e por fim o avião.

D - Primeiro cai o dirigível, seguido do helicóptero e por fim o avião, seguindose a ordem em que eles estão dispostos na folha de resposta.

E - Dirigível cai reto.

F - Avião continua reto, apenas caem o dirigível e o helicóptero. 


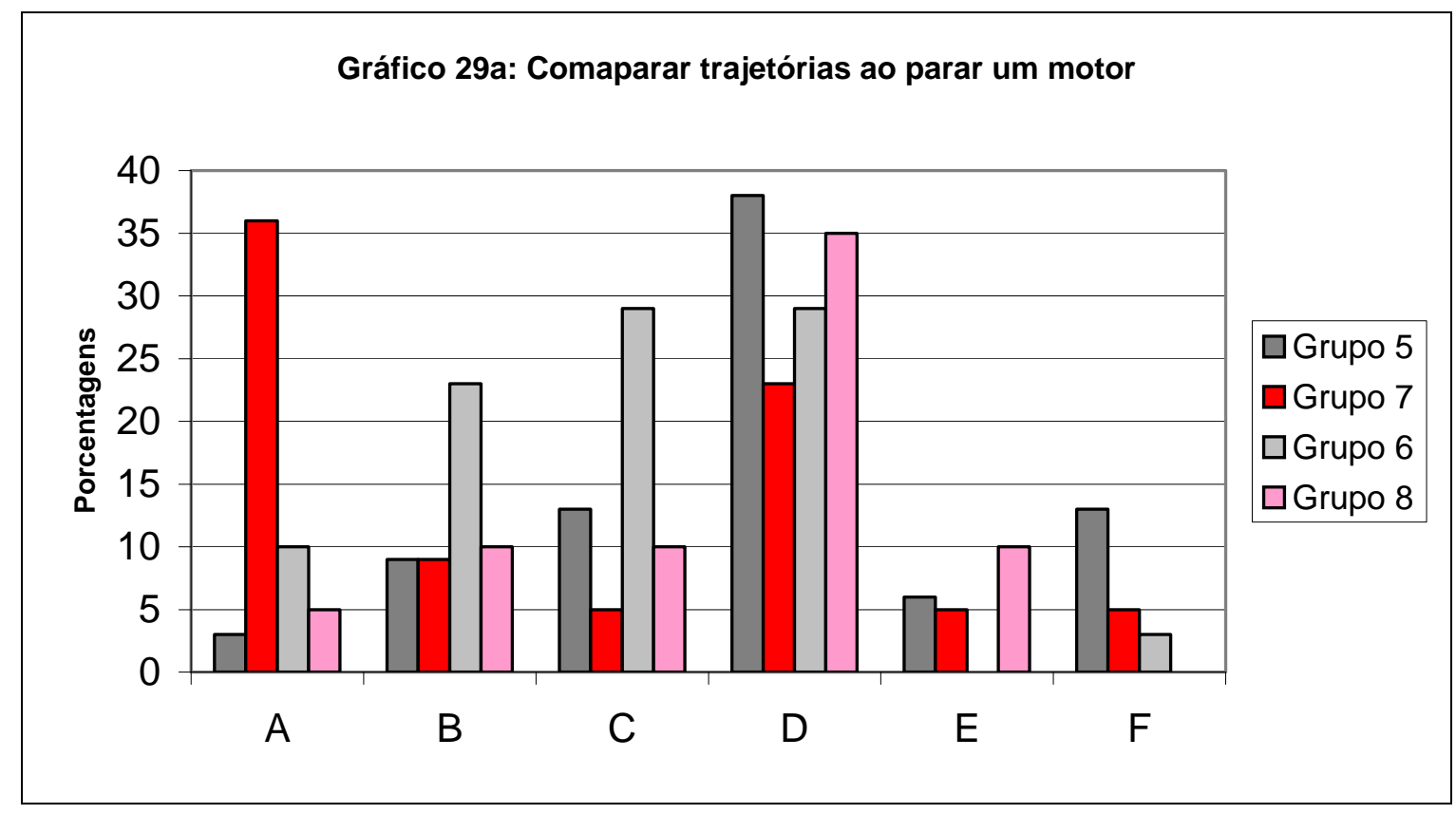

Gráfico 29a: Comparar as trajetórias de um dirigível, um helicóptero e um avião após parar seu motor durante o vôo - Os alunos assistiram a apenas um vídeo, os grupos ímpares a "Beakman” e os pares a “O Professor”.

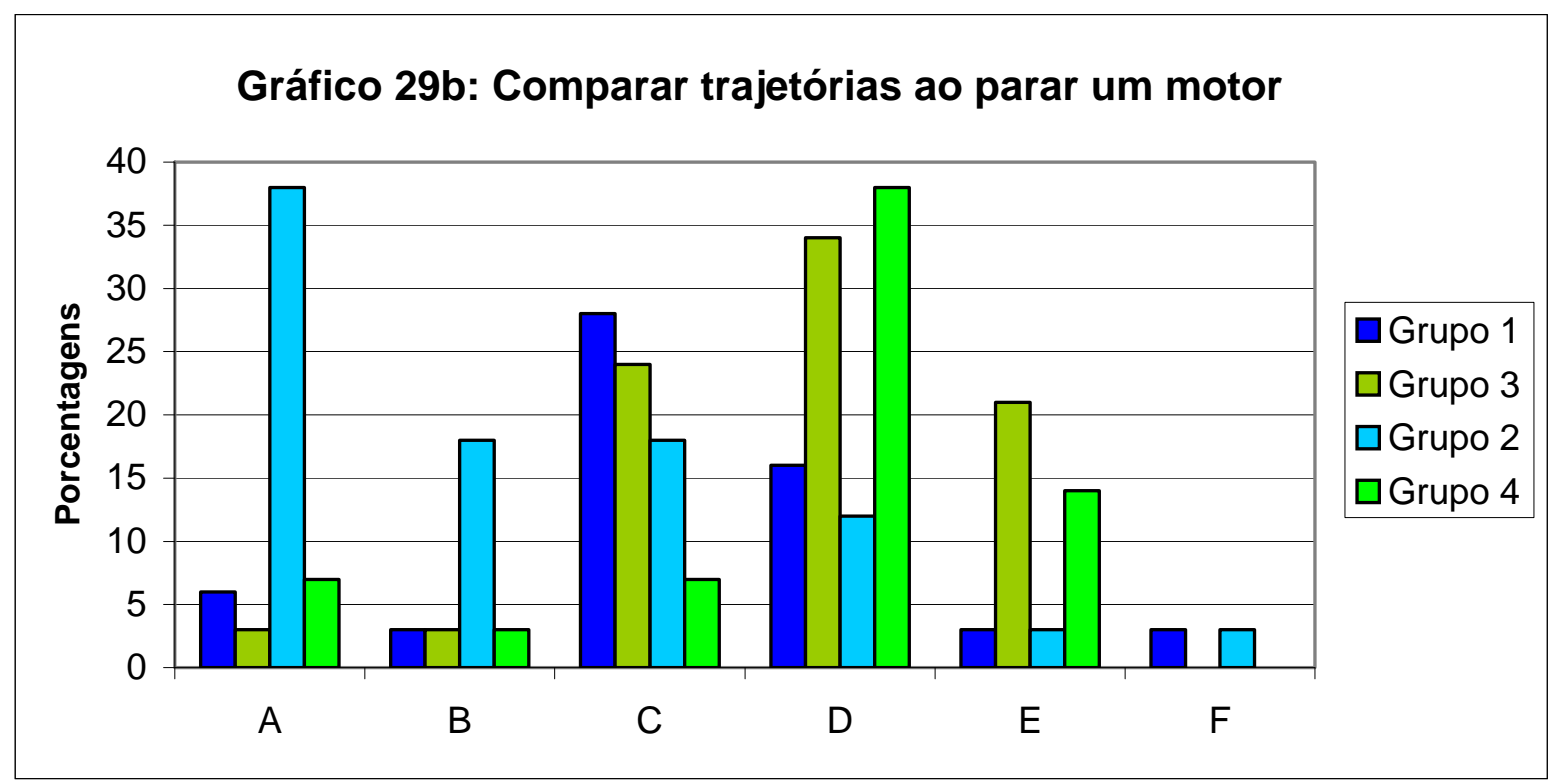

Gráfico 29b: Comparar as trajetórias de um dirigível, um helicóptero e um avião após parar seu motor durante o vôo - Os alunos assistiram aos dois vídeos; para os grupos ímpares a seqüência foi “Beakman” - “O Professor”, para os pares a ordem foi a inversa.

O princípio de vôo do dirigível não foi abordado nos vídeos, e a grande maioria dos alunos não têm conhecimento para inferir o que acontece nesse caso. O grupo 2 teve um desempenho muito discrepante, o que deve estar 
ligado ao desempenho no pré-teste; o gráfico 15 mostra também um conhecimento prévio sobre dirigíveis, acima dos demais grupos. A categoria que apresenta maior porcentagem de respostas é aquela em que os aparelhos caem na mesma ordem em que eles são apresentados no teste: o que está mais ao alto da diagramação (o avião) cai por último, e o mais abaixo na diagramação (o dirigível) cai primeiro.

Considerações sobre as questões elaboradas para o $2^{\circ}$ pós-teste da $3 .^{a}$ etapa e utilizadas como $1 .^{\circ}$ pós-teste da $4 .^{a}$ etapa

Os alunos, em sua maioria, demonstram maior conhecimento científico após assistir aos dois audiovisuais; não encontramos indícios de que a ordem de apresentação tenha papel significativo nesse sentido. Os alunos conseguem identificar adequadamente os principais componentes que permitem o vôo de aviões (cabine, motor, asa), pedindo que se explique a função deles (gráfico 26).

Podemos identificar um significativo avanço ao comparar os gráficos $26 \mathrm{a}$ e 26b: os alunos que assistiram aos dois vídeos tiveram um desempenho significativamente melhor, atingindo um conhecimento científico, e houve um melhor desempenho na escola privada, independentemente da ordem. A ordem, porém, parece ser relevante e ter melhores resultados quando se inicia com "Beakman" (grupos ímpares), mas os resultados da terceira etapa (gráfico 25a) mostram que a ordem pode ser indiferente. O gráfico $26 \mathrm{~b}$ mostra que 0 desempenho dos dois vídeos é melhor, trazendo indícios da cooperação de seus elementos. 
Foi possível identificar um maior avanço dos que assistiram aos dois vídeos, ao se compararem os gráficos $27 \mathrm{a}$ e $27 \mathrm{~b}$, avanço esse promovido, principalmente, pelo vídeo "Beakman", que discute a hélice do helicóptero como uma asa rotatória. No entanto, não há indícios de que a ordem da apresentação seja relevante.

Pudemos observar que foi mais fácil realizar a abstração trazida pela questão 13, do que a trazida anteriormente pela questão 8 do outro pós-teste; identificar semelhanças entre a asa de avião e ao telhado de uma casa foi mais fácil do que a abstração necessária para comparar a asa e um carro. Conseguimos identificar que, após assistir aos dois vídeos, uma parcela significativa dos alunos atingiram um conhecimento científico (gráfico 28b), tendo um desempenho melhor que aquele atingido na questão 8 do outro pósteste (gráfico 24b).

Identificamos, em relação à comparação entre os vôos do dirigível, avião e helicóptero, que a categoria que apresenta maior porcentagem de respostas é aquela em que os aparelhos caem na mesma ordem em que são apresentados na diagramação do teste: o que está mais ao alto da diagramação (o avião) cai por último e o mais abaixo na diagramação (o dirigível) cai primeiro. Acreditamos que isso esteja relacionado a não termos abordado o princípio de vôo do dirigível nos vídeos escolhidos; além disso, a maioria dos alunos não têm conhecimento prévio que possibilite inferir o que acontece com cada tipo de aeronave nesse caso. O desempenho diferenciado do grupo 2 deve estar ligado ao desempenho no pré-teste, apresentando também, esse grupo, conhecimento diferenciado, como mostra o gráfico 15, 
porquanto no pré-teste mais de $50 \%$ dos alunos do grupo 2 citam o balão ou o dirigível.

\subsection{Considerações finais sobre a pesquisa realizada}

Utilizar diferentes vídeos para a aprendizagem de conceitos científicos ligados a um mesmo tema mostrou-nos que a natureza do aprendizado é distinta para os diferentes vídeos, o que os torna complementares. Há uma grande variedade de vídeos produzidos para o ensino da Física, desde aqueles realizados dentro de projetos de ensino, vídeos comerciais e até projetos de produção amadora, que podem ser utilizados pelos professores em sala de aula.

Isso mostra que devemos explorar a linguagem audiovisual de diferentes maneiras e assim enriquecer o ambiente escolar. Trazer para dentro do ambiente escolar as tecnologias nas quais já estamos imersos em nosso cotidiano também traz a pluralidade de leituras.

Foi possível estudar temas que usualmente estão fora do ambiente escolar, como os conceitos científicos de Aerodinâmica, além de temas tradicionais do Ensino Médio, como alavancas, ao utilizarmos audiovisuais.

Foi possível identificar que o conhecimento apresentado no pré-teste dos alunos avançou na direção do conhecimento científico nos pós-testes. Isso indica que os vídeos puderam ser assimilados pelos alunos que se apropriaram dos elementos presentes nos vídeos para transformar seus conhecimentos, revelando que esses vídeos atuam na zona de desenvolvimento proximal (Vygotsky, 1984) dos adolescentes em idade 
escolar, propiciando a construção do conhecimento na direção do saber científico.

Os vídeos exploram os elementos da linguagem audiovisual de formas diferentes, tanto em relação ao enquadramento, como em relação ao áudio, que em "O Professor" fica restrito quase exclusivamente aos diálogos. "Beakman" explora melhor os recursos da linguagem audiovisual, e foi dele que os alunos mais gostaram.

Um professor que optar por exibir apenas um vídeo em sua programação de atividades, deve utilizar os mais divertidos, que valorizam os elementos da linguagem audiovisual e valorizam a fruição dos alunos (espectadores), pois eles apresentam desempenhos equivalentes aos mais monótonos e parecidos com a aula tradicional.

O professor deve estar ciente de que as diferentes formas de tratar o argumento levaram a diferentes interpretações dos conceitos científicos tratados nos vídeos.

Ao exibir vídeos para os alunos, a utilização de dois vídeos distintos mostrou-se mais eficiente, pois juntos eles obtêm resultados melhores que cada um deles individualmente. Assim, a pesquisa apresenta resultados que permitiram identificar em audiovisuais de diferentes naturezas a cooperação que ocorre quando são mesclados momentos de sistematização e momentos de prazer, e os realizadores de audiovisuais educativos devem ter consciência disso.

Identificamos que, em relação à maioria dos testes, não há alteração significativa causada pela inversão da ordem de apresentação dos vídeos, o 
que contrariou nossas expectativas, já que nos parecia relevante a seqüência de apresentação deles.

Nos casos em que pudemos identificar pequenas diferenças, a ordem de apresentação que produziu um maior avanço no conhecimento científico foi "O Professor"-_Beakman"; mas nesses casos também identificamos que, no $1 .^{\circ}$ pós-teste, "Beakman" teve um melhor desempenho individual, e o resultado final pode estar mascarando esse fato observado no desempenho individual.

Dessa forma, entendemos que a ordem de apresentação pode ser escolhida pelo professor em função de suas prioridades, já que não foi possível determinar um fator relevante na ordem da apresentação.

Os dois conjuntos de vídeos utilizados apresentaram resultados que mostraram a aprendizagem de conceitos científicos por meio de visões complementares, mas não identificamos nenhum caso em que fosse possível identificar que eles estivessem competindo; no segundo pós-teste ocorreu um significativo progresso em relação às generalizações.

A pesquisa mostrou que há limitações em relação ao aprendizado, porém isso pode ser superado se utilizadas as metodologias existentes para uso dos audiovisuais, como as discutidas por Miléo.

Em nossa pesquisa identificamos a dificuldade de comparar e extrapolar o conceito de perfil de asa para o perfil de um carro; esse tipo de abstração não parece ter sido possível por meio dos vídeos utilizados, o que reforça a importância do professor nos processos educativos, identificando limitações e propondo outras formas de interação com os conhecimentos científicos, permitindo-se superar as dificuldades. 
O pré-teste indicou diferenças no mundo vivencial dos alunos das escolas públicas e particulares, como o medo associado ao avião entre os alunos da escola pública - o qual não ocorre entre alunos da escola particular, mais familiarizados com esse meio de transporte.

Os alunos da escola pública têm maior interesse em conhecer o princípio de vôo do avião, enquanto que na escola privada o maior interesse está na utilidade ou na diversão que o avião pode-lhes proporcionar.

Os alunos da escola particular apresentaram em alguns casos desempenhos melhores que os alunos da escola pública, o que pode estar relacionado ao maior uso de vídeos didáticos para fins educativos em escolas particulares, pois que os alunos de escola particular estão mais habituados a identificar quais respostas se esperam deles, principalmente em situações de avaliação. O pré-teste também indicou uma maior familiaridade com esses temas entre os alunos da escola particular.

Acreditamos que os professores, ao utilizar audiovisuais em salas de aula, passam a mediar as situações de aprendizagem de forma mais prazerosa, e os alunos experimentam o sentido da fruição explicitamente explorada em audiovisuais que se expressam adequadamente por meio da linguagem audiovisual.

O audiovisual é uma entre as diversas formas de recuperar a fruição nas estratégias de aprendizagem, o que nunca deveria ter deixado de estar presente na escola, pois a fruição também está presente numa educação problematizadora e transformadora, em que o educando é protagonista e o professor tem o papel de educador e especialista, identificando e 
promovendo meios plurais de aprendizagem, construindo o conhecimento em comunhão.

Muitas perguntas ainda permaneceram abertas. É preciso explorar mais profundamente a linguagem audiovisual e seus usos no ensino da Física, sendo também necessário investigar metodologias e formas de inseri-la na formação de educadores, nos centros de formação inicial e na formação continuada. A falta de habilidade e de desenvoltura na utilização e na produção de atividades educacionais que explorem o potencial dessa linguagem, contribui para que os professores atuem de forma preconceituosa e inadequada em relação ao uso de audiovisuais em sala de aula, pelo que precisamos buscar novos caminhos para superar essa postura e trazer para a sala de aula as contribuições e a interatividade desse meio de comunicação. 


\section{Bibliografia:}

ALMEIDA, Cândido José Mendes de. Uma nova ordem audiovisual: novas tecnologias de comunicação. São Paulo: Summus; EDUSP, 1988.

ALMEIDA, M. C. (Coord). TV Escola: orientações para o uso da televisão e do vídeo em sala de aula. São Paulo: FDE, 1996.

COZENDEY, S. G.; ARAÚJO, C. P.; SOUZA, M. O.; GOMES A. F. Uma experiência de desenvolvimento de vídeos didáticos para a apresentação de conceitos básicos de Física em escolas secundárias da região Norte-Fluminense. Rio de Janeiro: XVI SNEF, 2005.

BABIN, Pierre; KOULOUMDJIAN, Marie-France. Os novos modos de compreender: a geração do audiovisual e do computador. São Paulo: Paulinas, 1989.

BACCEGA, Maria Aparecida. Comunicação e linguagem: discursos e ciência. São Paulo: Moderna, 1998.

BELLONI, M. L. A televisão como ferramenta pedagógica na formação de professores. Educação e Pesquisa, São Paulo, v. 29, n2, jul/dez. 2003, p. 207-301.

BERGER, M. A.; NUNES, A. K. F. Curso TV Escola e os desafios de hoje: uma alternativa de formação continuada do professor. Revista do Mestrado em Educação. São Cristóvão - Sergipe, v. 8, jan./jun 2004, p. 23-32.

BITTENCOURT, Diomar da Rocha Santos. Análise do projeto de ensino de Física Mecânica. Dissertação de Mestrado em Ensino de Ciências (Modalidade: Física). São Paulo: IFUSP/FEUSP, 1977.

BRASIL, MEC/Secretaria de Educação a distância. Integração das Tecnologias na Educação. Brasília: SEED, 2005.

CANIATO, Rodolpho. Um projeto brasileiro para o ensino de Física. Tese de Doutoramento. Rio Claro: Faculdade de Filosofia, Ciências e Letras de Rio Claro, 1973.

CARVAlho, Anna M. P. de. O ensino de Física na Grande São Paulo - estudo sobre um processo de transformação. Tese de Doutorado em Educação. São Paulo: FEUSP, 1972.

CITELLI, Adilson Odair. Comunicação e Educação - Aproximações. In: BACCEGA, Maria Aparecida. Gestão de processos comunicacionais. São Paulo: Atlas, 2002, p. 101-114.

SENAC, 2000.

Comunicação e educação. A linguagem em movimento. São Paulo: (Org.). Outras linguagens na escola. São Paulo: Cortez, 2000. 
COUTINHO, L. M. Imagens sem fronteiras: a gênese da TV Escola no Brasil. In: Santos, G. L. Tecnologias na educação e formação de professores. Brasília: Plano, 2003.

DIB, Cláudio Zaki. Tecnologia da educação e aprendizagem de Física. Tese de Doutorado em Física. São Paulo: IFUSP, 1972.

FERRÉS, J.; ACUÑA, L. Vídeo e educação. Porto Alegre: Artes Médicas, 1996.

FORESTI, J. A. A complexidade da teleducação no Canal Futura. Porto Alegre: EDIPUCRS, 2001.

FRANCO, Marília S. et alii. Cinema: uma introdução à produção cinematográfica. São Paulo: FDE, 1992.

FRANCO, Marília da Silva. Escola audiovisual. Tese de Doutorado em Comunicação. São Paulo: ECA/USP, 1987.

FREIRE, Paulo. Ação cultural para a liberdade. 9. ed. São Paulo: Paz e Terra, 2001. (Coleção “O Mundo Hoje”, v. 10.)

Extensão ou comunicação? São Paulo, Paz e Terra, 1992.

A educação como prática da liberdade. Rio de Janeiro: Paz e Terra, 1981.

Pedagogia do Oprimido. Rio de Janeiro: Paz e Terra, 1974.

GIACOMANTONIO, Marcello. O ensino através dos Audiovisuais. São Paulo: Summus; EDUSP, 1981.

IANNI, Octávio. O Príncipe Eletrônico. In: BACCEGA, Maria Aparecida. Gestão de processos comunicacionais. São Paulo: Atlas, 2002, p. 49-68.

LARANJEIRAS, Cassio Costa. Redimensionamento e ensino de Física numa perspectiva histórica. Dissertação de Mestrado em Ensino de Ciências (Modalidade: Física). São Paulo: IFUSP/FEUSP, 1994.

LEVY, Pierre. As tecnologias da inteligência. Rio de Janeiro: Editora 34, 1993.

LIMA C. M. Educação a distância e TV Escola: apropriações de professores em formação contínua. Tese de Doutoramento. Campinas: Pontifícia Universidade Católica de Campinas, 2000.

LOPES, José Júnio. Leituras do vídeo didático de Física: estudo de alguns episódios. Dissertação de Mestrado em Ensino de Ciências (Modalidade: Física). São Paulo: IFUSP/FEUSP, 1995.

MACHADO, E. V. O vídeo como mediador da comunicação escolar. Tese de Doutorado em Educação. São Paulo: FEUSP, 2001.

MANSUR, Anahí. A utilização das mensagens dos meios na escola. In: Tecnologia educacional. Porto Alegre: Artes Médicas, 1997. 
MARTÍN-BARBERO, Jésus. Dos meios às mediações: hegemonia, comunicação e cultura. Rio de Janeiro: UFRJ, 1997.

MILÉO, Pedro Romano Filho. Os meios audiovisuais no ensino de Física: produção, classificação, e dinâmicas de utilização de audiovisuais educativos de física na sala de aula. Dissertação de Mestrado em Ensino de Ciências (Modalidade: Física). São Paulo: IFUSP/FEUSP, 1994.

MORAN, José Manuel. Como ver televisão: leitura crítica dos meios de comunicação. São Paulo: Paulinas, 1991.

MURAMATSU, Mikiya. Produção, utilização e avaliação de filmes didáticos de Física. Dissertação de Mestrado em Ensino de Ciências (Modalidade: Física). São Paulo: IFUSP/FEUSP, 1976.

OLIVEIRA, Marta Kohl. Pensar a educação: contribuições de Vygotsky. In:

FERREIRO, Emilia; CASTORINA, José Antonio; LERNER, Delia. Piaget e Vygotsky: novas contribuições para o debate. 6. ed. São Paulo: Ática, 2003.

PACCA, Jesuína Lopes de Almeida. Análise do desempenho de alunos frente a objetivos do projeto de ensino de Física. Dissertação de Mestrado em Ensino de Ciências (Modalidade: Física). São Paulo: IFUSP/FEUSP, 1976.

PENTEADO, Heloísa Dupas. Comunicação Escolar, uma metodologia de ensino. São Paulo: Salesiana, 2002.

Pedagogia da comunicação. São Paulo: Cortez, 1998.

Televisão e escola: conflito ou cooperação? São Paulo: Cortez, 1991.

PERNAMBUCO, Marta Maria Castanho Almeida. Ensino de Ciências a partir dos problemas da comunidade. Dissertação de Mestrado em Ensino de Ciências (Modalidade: Física). São Paulo: IFUSP/FEUSP, 1981.

PINTO, Álvaro Vieira. Ciência e existência: problemas filosóficos da pesquisa científica. 3. ed. Rio de Janeiro: Paz e Terra, 1985.

PRETTO, Nelson De Luca. A universidade e o mundo da comunicação: análise das práticas audiovisuais das universidades brasileiras. Tese de doutorado em Comunicação. São Paulo: ECA/USP, 1994.

ROCCO, M. Thereza Fraga. Linguagem autoritária, televisão e persuasão. São Paulo: Brasiliense, 1989.

SAAD, Fuad Daher. Análise do projeto FAI: uma proposta de um curso de Física auto-instrutivo para o segundo grau. Dissertação de Mestrado em Ensino de Ciências (Modalidade: Física). São Paulo: IFUSP/FEUSP, 1977.

SALIBA, Maria Eneida Fachini. Cinema contra cinema: o cinema educativo de Canuto Mendes (1922-1931). São Paulo: Annablume, 2003. 
SANTAELLA, Lúcia. A assinatura das coisas: Peirce e a Literatura. Rio de Janeiro: Imago, 1992.

SCHIEL, D.; MAGALHÃES, M. G. M.; GUERRINI I. M.; MAREGA Jr., E. Utilizando tecnologia computacional na análise quantitativa de movimentos: uma atividade para alunos do Ensino Médio. Revista Brasileira de Ensino de Física. São Paulo: vol. 24, n. 2, junho de 2002.

SCHVARZMAN, Sheila. Humberto Mauro e as imagens do Brasil. São Paulo: UNESP, 2004.

SILVA, Manuel Costa e. Guia profissional do audiovisual 1998/1999: cinema, televisão e vídeo. Lisboa: Dom Quixote, 1998.

SIQUEIRA, D. C. O. A Ciência na televisão: mito, ritual, espetáculo. São Paulo: Annablume, 1999.

SOARES, Ismar de Oliveira. Metodologia da educação para a comunicação e gestão comunicativa no Brasil e na América Latina. In: BACCEGA, M. Aparecida. Gestão de processos comunicacionais. São Paulo: Atlas, 2002, p. 113-132.

. Comunicação/Educação, a emergência de um novo campo e o perfil de seus profissionais. In: Contato - Revista Brasileira de Comunicação, Arte e Educação. Brasília, ano 1, n. 2, jan./mar. 1999, p. 5-75.

1996.

. Sociedade da informação ou da comunicação? São Paulo: Cidade Nova,

SOARES, Ismar de Oliveira; COSTA, Maria Cristina. Planejando os projetos de comunicação. In: BACCEGA, M. Aparecida. Gestão de processos comunicacionais. São Paulo: Atlas, 2002, p. 157-176.

VIANNEY, João et alii. A Universidade Virtual no Brasil: o ensino superior a distância no país. Tubarão: Unisul, 2003.

VYGOTSKY, Lev S. A construção do pensamento e da linguagem. São Paulo: Martins Fontes, 2001.

A formação social da mente. São Paulo: Martins Fontes, 1984. 
7. Anexos 


\section{Anexo 1}

\section{Elementos da linguagem audiovisual}

"Uma imagem vale mais que mil palavras".

Quando se discutem os elementos que compõem a linguagem audiovisual, as seqüências, os planos, a angulação, o movimento de câmera, o som e a edição são os temas mais freqüentemente elencados ${ }^{55}$, e também os mais explícitos num produto audiovisual; mas eles não são os únicos ${ }^{56}$, e a nomenclatura utilizada para caracterizá-los não é padronizada, apresentando variantes para os mesmos termos, dependendo do autor consultado. Ainda assim é possível identificar nelas alguma convergência.

O plano é o elemento mais evidente da linguagem audiovisual, é o conjunto de imagens captadas e registradas por uma câmera durante a tomada de uma cena, e está contido no espaço e no tempo. Ele também é o menor fragmento de um audiovisual após sua edição/montagem, tendo normalmente duração específica e um único enquadramento. No entanto com a evolução tecnológica e a criação de objetivas com foco variável, os planos podem apresentar dois ou mais enquadramentos (zoom), e isso depende da lente utilizada na captação. Há casos em que se dão denominações como plano-

\footnotetext{
${ }^{55}$ Franco, 1987; Miléo, 1994; TV na Escola e os Desafios de Hoje: Curso de extensão, SEED/MEC, Brasília, 2001.

${ }^{56}$ Também podem ser encontradas referências ao argumento, tratamento, roteiro, ritmo, cenografia, fotografia entre outros.
} 
seqüência, para ressaltar que durante a tomada da cena há movimento de câmera acompanhando a ação por diferentes espaços ou cenários, sem a interrupção do plano.

A seqüência é um conjunto de planos que formam um bloco e apresentam as informações que dão sentido à parte da narrativa; ela pode propiciar tanto uma unidade narrativa como uma unidade técnica, por exemplo, todos os planos realizados numa mesma locação.

\section{O enquadramento de um plano}

O enquadramento inclui uma série de elementos que compõem o campo visual apresentado ao espectador, os quais formam o ponto de vista que o espectador terá da narrativa: entre eles a escolha da porção do cenário, o ângulo pelo qual a câmera exibe a ação, que imagens estão mais próximas ao expectador etc.

Os planos podem ser classificados de acordo com o enquadramento escolhido para a tomada de cena, e, de uma forma aproximada, o enquadramento pode ser pensado como a posição e a distância aparentes em que a câmera está em relação ao objeto principal da ação. Cada uma das categorias apresentadas a seguir para os planos exerce uma função específica na linguagem audiovisual. 
No plano geral (PG), a câmera parece estar distante, tem como função contextualizar a ação no espaço e no tempo, apresentando uma visão ampla do cenário, rico em informações que ambientam o espectador no contexto em que ocorre a ação. Em alguns casos, é chamado de grande plano geral, quando se trata do plano mais abrangente que se pode ter numa tomada.

O plano de conjunto $(\mathrm{PC})$ é um enquadramento um pouco mais próximo que um plano geral, mostrando os personagens e o ambiente em que se encontram. Ambienta o espectador na ação, valorizando o personagem e mantendo o ambiente como pano de fundo.

No plano médio (PM), a câmera parece estar próxima e acompanhar a ação, exercendo a função narrativa; sua forma mais comum apresenta a pessoa da cintura para cima, mas há variantes, como o plano americano, que mostra a pessoa do joelho para cima, ou plano aberto, que mostra a pessoa inteira, sempre privilegiando a ação, nunca cortando a pessoa nas articulações, mas logo acima delas.

No primeiro plano (PP), a câmera parece estar muito próxima da ação, dá destaque ao personagem ou objeto na narrativa, prende a atenção do espectador na ação individual.

No close-up (Close), a câmera parece estar extremamente próxima, podendo desvelar aspectos íntimos do que ocorre na ação, revelando pensamentos e o interior do personagem; tem a função de amplificar a intensidade dramática, apresenta nitidamente a expressão do ator ou detalhes dos objetos, enquadra o essencial para chamar a atenção e apresentar ao espectador, numa cena, detalhes importantes que poderiam escapar num enquadramento em primeiro plano. 
Plano detalhado ou plano de detalhe (PD), por meio do qual a câmera parece estar junto ao objeto ou ao personagem, a poucos centímetros ou até mais próxima, mostrando em pormenores uma parte essencial do assunto; apresenta grande impacto visual e tempo de leitura muito curto.

\section{Os movimentos de câmera num plano}

Durante a captação, a câmera pode permanecer fixa e a ação se passar diante de seu campo visual, ou apresentar movimentos que acompanham e enriquecem as imagens do ponto de vista que se quer apresentar.

A panorâmica (PAN) é o movimento de câmera que se dá sem que ela saia do lugar, apenas rotacionando, na vertical ou na horizontal; é equivalente a girar a cabeça para os lados ou para cima e para baixo, varrendo o cenário para trazer informações que estavam ocultas, fora do campo visual. A panorâmica invertida tem a mesma função da panorâmica, mas ocorre com o movimento da câmera ao redor do personagem ou do objeto central, de tal forma que se modifica o campo visual, mas o personagem ou objeto permanece nele.

O travelling é o movimento em que a câmera se desloca, movendo-se ao longo de trilhos, ou presa à grua, ao carro ou ao corpo do operador de câmera; ela é fixada a algum objeto móvel, permitindo que a câmera acompanhe o movimento dos objetos. O dolly é o deslocamento da câmera em que a pessoa ou objeto está parado e o movimento que se vê é o movimento da câmera. 
O zoom é um movimento de câmera que não corresponde a nenhum movimento físico dela; trata-se de um efeito óptico que ocorre quando se utiliza uma objetiva que permite a variação da distância focal de seu conjunto de lentes, variando o campo visual e o aumento da imagem, o que é normalmente interpretado pelo espectador como movimento de aproximação ou de afastamento da câmera.

\section{O ângulo e a posição da câmera num plano}

As posições relativas entre a câmera e o personagem ou objeto presentes na ação produzem efeitos expressivos, estéticos e de reforço de significado, os quais influenciam a leitura da imagem; assim, a angulação dá força à narrativa, adicionando o ponto de vista que se impõe à imagem, na escolha feita pelo diretor.

A câmera alta (plongée) corresponde à câmera posicionada acima da ação, com tomada de cena de cima para baixo; ela minimiza o personagem e demonstra o predomínio da ação, sendo um ponto de vista que normalmente reforça a inferioridade do personagem, diminuindo sua força e sua importância.

A câmera baixa (contraplongée) corresponde à câmera posicionada abaixo do personagem ou objeto, muitas vezes no chão; com tomada de cena de baixo para cima, ela dá austeridade e força ao personagem, colocando-o em posição dominante.

A câmera normal capta a ação à altura dos olhos de uma pessoa, como a visão normal que temos do mundo, sem trazer uma carga expressiva do ponto de vista do observador à cena. 


\section{A edição dos planos}

Esse é o momento de recriação do que foi captado: de todos os planos filmados, escolhem-se quais partes deles serão incluídas no produto final, no audiovisual que será veiculado e também em que ordem, podendo-se alterar as seqüências filmadas, recriando-se novas seqüências ${ }^{57}$ e até apresentando-se duas ou mais seqüências ao mesmo tempo na tela ${ }^{58}$, recurso muito utilizado em videoclipes musicais. É na edição que se inserem no produto audiovisual o som, a trilha sonora e os efeitos especiais.

\footnotetext{
${ }^{57}$ O filme Blade Runner de Ridley Scott foi editado em quatro versões já exibidas: o original americano e a versão internacional lançados em 1982, com final modificado por imposição do estúdio (narrativa em off de Harrison Ford, "final feliz" e cenas de arquivo de $\boldsymbol{O}$ Iluminado, do Kubrick). A versão do diretor, lançada em 1992, e a versão final do diretor lançada em 2007 têm o unicórnio e o final original do diretor. ${ }^{58}$ O filme Hulk de Ang Lee, 2003, em vários momentos, utiliza a divisão da tela em duas ou mais partes, cada uma apresentando uma sequiência. São apresentados ao mesmo tempo ao espectador diferentes ângulos de um mesmo fato, ou diferentes tramas correlacionadas.
} 